Geraldo Francisco Donegá Zafalon

\title{
Aplicação de estratégias híbridas em algoritmos de alinhamento múltiplo de sequências para ambientes de computação paralela e distribuída
}


Geraldo Francisco Donegá Zafalon

\section{Aplicação de estratégias híbridas em algoritmos de alinhamento múltiplo de sequências para ambientes de computação paralela e distribuída}


Geraldo Francisco Donegá Zafalon

\section{Aplicação de estratégias híbridas em algoritmos de alinhamento múltiplo de sequências para ambientes de computação paralela e distribuída}

Tese apresentada à Escola Politécnica da Universidade de São Paulo para obtenção do título de Doutor em Ciências

Área de Concentração:

Engenharia de Computação

Orientador:

Prof. Dra. Liria Matsumoto Sato

Co-orientador:

Prof. Dr. José Márcio Machado (In Memorian)

São Paulo 
Este exemplar foi revisado e alterado em relação à versão original, sob responsabilidade única do autor e com a anuência de seu orientador.

São Paulo, 08 de Dezembro de 2014.

Assinatura do autor

Assinatura do orientador

\section{Catalogação-na-publicação}

Zafalon, Geraldo Francisco Donegá

Aplicação de estratégias híbridas em algoritmos de alinhamento múltiplo de sequências para ambientes de computação paralela e distribuída / G.F.D. Zafalon. -- versão corr. -- São Paulo, 2014.

$122 \mathrm{p}$.

Tese (Doutorado) - Escola Politécnica da Universidade de São Paulo. Departamento de Engenharia de Computação e Sistemas Digitais.

1.Bioinformática 2.Algoritmos (Otimização) 3.Processamento paralelo. I.Universidade de São Paulo. Escola Politécnica. Departamento de Engenharia de Computação e Sistemas Digitais II.t. 
Dedico este trabalho ao Senhor Jesus Cristo, a minha Esposa Erica Carine Lima Zafalon, a minha Mãe Maria Aparecida Donegá Zafalon e ao meu Pai Geraldo Zafalon. 


\section{Agradecimentos}

Agradeço primeiramente à Deus, meu Divino Pai Eterno, através das bênçãos concedidas pelo meu amado Jesus Cristo, por ter me permitido chegar até aqui e guiado-me em todos os momentos da minha vida. Agradeço pela intercessão contínua, junto a Jesus, a Nossa Senhora Aparecida, Mãe Rainha e Santo Expedito, Nossa Senhora de Fátima e Nossa Senhora Desatadora dos Nós.

Agradeço de maneira incomensurável a minha Esposa Erica (Neguinha), o amor da minha vida, por todos os momentos juntos, pelo amor, pelo carinho, pela compreensão, pela paciência, por todos os momentos de superação das dificuldades, minha eterna companheira. Aos meu pais, Maria Aparecida e Geraldo, por todo o amor, carinho, presença e suporte durante todos os dias, desde que eu nasci e, principalmente, nos meus estudos, até hoje.

Aos meus familiares que também estiveram presentes nessa caminhada e sempre rezaram por mim, minha Sogra Fátima, meu sogro Edison, meu cunhado Erick, minha tia Madalena, meu tio Adalberto, minha prima Vivian.

Aos meus grandes amigos e irmãos, que me acompanharam durante todo o tempo e proporcionaram e proporcionam muitos bons momentos: Valdeir Alves, Suzana Alves, a nossa Clara que está vindo, Adenilson Borsatto, Marilda Borsatto, Bianca Borsatto, Raphael Fagliari, Paulo Fagliari, Marcos Dutra, Raul Strombeck, Daniel Franco Pedro, Álvaro Guilhermith, Marcelo Della Torre e José Leôncio. Aos meus grandes amigos e irmãos da Unesp: Chang Hsun Ming, Paula Rahal, Carlos Valêncio, Adriano Cansian, Rogéria Gratão de Souza, Leandro Neves, Mario Tronco, Rosemar de Carvalho Brena, Alex Antônio dos Santos, Lenira Bueno, Thiago Parolin, Evandro Marucci, Anderson 
Rici, Paulo Scarpelini e em especial, ao amigo Julio Cesar Momente, por todos os anos de convívio, trabalho, parceria e amizade na Universidade.

Ao meu grande amigo, orientador, mentor e formador, Prof. Dr. José Márcio Machado (in Memorian), a quem devo muito por tudo que alcancei em todos esses anos, por todas as orientações em momentos de dúvidas, todas as boas conversas nos almoços e jantares, e todos os encaminhamentos científicos e pessoais. Se Deus quiser e me permitir, quero dar sequência no trabalho desenvolvido pelo Prof. José Márcio, com a mesma ética e excelência que lhe eram de costume.

À Prof. Dra. Liria Matsumoto Sato, também minha orientadora, pelo enorme carinho, atenção, que teve comigo ao longo deste período. Além disso, pela grande contribuição técnica no desenvolvimento deste trabalho e certamente, se Deus quiser, continuaremos em constante parceria, para o desenvolvimento de novos projetos.

A um grande amigo, Prof. Dr. José Roberto Almeida Amazonas, do Departamento de Telecomunicações, PTC/Poli/USP, pela amizade e parceria científica que construímos nos últimos anos, a qual, se Deus quiser, continuaremos firmes e fortes.

Às minhas grandes amigas e irmãs do Departamento de Ciências de Computação e Estatística (DCCE), da Unesp de São José do Rio Preto, Olga Maria Rissi Ferreira, Adriana Félix Ártico e a Martinha, por todas as ajudas em todos os momentos e pela sólida amizade que construímos, na fraternidade de Deus.

A todos os funcionários da Poli/USP, especialmente aos que eu tive mais contato, do Programa de Pós-Graduação em Engenharia Elétrica e do Departamento de Engenharia de Computação e Sistemas Digitais, PCS/Poli/USP.

À Unesp/Ibilce pelos incentivos financeiros e físicos durante todo este período, que me permitiram o desenvolvimento deste trabalho e aos seus funcionários pela prestatividade sempre. Esta pesquisa tornou-se possível graças aos recursos computacionais disponibilizados pelo Núcleo de Computação Científica (NCC/GridUNESP) da Universidade Estadual Paulista (UNESP). 
Eis como deveis rezar: PAI NOSSO que estais no céu, santificado seja o vosso nome; venha a nós o vosso Reino; seja feita a vossa vontade, assim na terra como no céu. O pão nosso de cada dia nos dai hoje; perdoai-nos as nossas ofensas, assim como nós perdoamos aos que nos ofenderam; e não nos deixeis cair em tentação, mas livrai-nos do mal. 


\section{Resumo}

A Bioinformática tem se desenvolvido de forma intensa nos últimos anos. A necessidade de se processar os grandes conjuntos de sequências, sejam de nucleotídeos ou de aminoácidos, tem estimulado o desenvolvimento de diversas técnicas algorítmicas, de modo a tratar este problema de maneira factível. Os algoritmos de alinhamento de alinhamento múltiplo de sequências assumiram um papel primordial, tornando a execução de alinhamentos de conjuntos com mais de duas sequências uma tarefa viável computacionalmente. No entanto, com o aumento vertiginoso tanto da quantidade de sequências em um determinado conjunto, quanto do comprimento dessas sequências, a utilização desses algoritmos de alinhamento múltiplo, sem o acoplamento de novas estratégias, tornou-se algo impraticável. Consequentemente, a computação de alto desempenho despontou como um dos recursos a serem utilizados, através da paralelização de diversas estratégias para sua execução em grandes sistemas computacionais. Além disso, com a contínua expansão dos conjuntos de sequências, outras estratégias de otimização passaram a ser agregadas aos algoritmos de alinhamento múltiplo paralelos. Com isso, o desenvolvimento de ferramentas para alinhamento múltiplo de sequências baseadas em abordagens híbridas destaca-se, atualmente, como a solução com melhor aceitação. Assim, no presente trabalho, pode-se verificar o desenvolvimento de uma estratégia híbrida para os algoritmos de alinhamento múltiplo progressivos, cuja utilização é amplamente difundida, em Bioinformática. Nesta abordagem, conjugou-se a paralelização e o particionamento dos conjuntos de sequências, na fase de construção da matriz de pontuação, e a otimização das fases de construção da árvore filogenética e de alinhamento múltiplo, através dos algoritmos de colônia de formigas e simulated annealling paralelo, respectivamente.

Palvras-chave: Bioinformática. Alinhamento múltiplo de sequências. Algoritmos de otimização. Processamento paralelo. 


\section{Abstract}

Bioinformatics has been developed in a fast way in the last years. The need for processing large sequences sets, either nucleotides or aminoacids, has stimulated the development of many algorithmic techniques, to solve this problem in a feasible way. Multiple sequence alignment algorithms have played an important role, because with the reduced computational complexity provided by them, it is possible to perform alignments with more than two sequences. However, with the fast growing of the amount and length of sequences in a set, the use of multiple alignment algorithms without new optimization strategies became almost impossible. Therefore, high performance computing has emerged as one of the features being used, through the parallelization of many strategies for execution in large computational systems. Moreover, with the continued expansion of sequences sets, other optimization strategies have been coupled with parallel multiple sequence alignments. Thus, the development of multiple sequences alignment tools based on hybrid strategies has been considered the solution with the best results. In this work, we present the development of a hybrid strategy to progressive multiple sequence alignment, where its using is widespread in Bioinformatics. In this approach, we have aggregated the parallelization and the partitioning of sequences sets in the score matrix calculation stage, and the optimization of the stages of the phylogenetic tree reconstruction and multiple alignment through ant colony and parallel simulated annealing algorithms, respectively.

Keywords: Bioinformatics. Multiple sequence alignment. Optimization algorithms. Parallel processing. 


\section{Lista de Figuras}

1 Exemplo de Célula Animal. . . . . . . . . . . . . . . . p. 25

2 Processo de Transcrição e Tradução. . . . . . . . . . . . . . . . . p. 26

3 Interligação entre as bases que compõem o DNA. . . . . . . . . . . . p. 26

4 Início da construção da matriz de valores para o algoritmo de NeedlemanWunsch. . . . . . . . . . . . . . . . p. 30

5 Processo de construção da matriz de valores para o algoritmo de NeedlemanWunsch. . . . . . . . . . . . . . . . . p. 30

6 A matriz de valores finalizada para o algoritmo de Needleman-Wunsch, à esquerda, e a realização do backtracking, com o alinhamento final, à direita. . . . . . . . . . . . . . . . . . . p. 31

7 Processo de construção da matriz de valores para o algoritmo SmithWaterman. . . . . . . . . . . . . . . . . p. 32

8 A matriz de valores finalizada para o algoritmo Smith-Waterman, à esquerda, e a realização do backtracking, à direita. . . . . . . . . . . . . p. 33

9 Alinhamentos locais ótimos. . . . . . . . . . . . . . . p. 33

10 Exemplo de cálculo diagonal do Dialign. . . . . . . . . . . . . . . . . p. 54

11 Fluxograma do algoritmo para distribuir pares de sequências às unidades de processamento. . . . . . . . . . . . . . . p. 63

12 Fluxograma do algoritmo de construção da matriz de pontuação. . . . . . p. 64 
13 Ilustração do mecanismo de particionamento das sequências a serem alinhadas. . . . . . . . . . . . . . . . . . . p. 69

14 Ilustração do particionamento da estimativa de pontos. . . . . . . . . . . p.73

15 Ilustração da árvore filogenética. . . . . . . . . . . . . . . . . . p. 78

16 Ilustração da execução do alinhamento múltiplo em um primeiro passo. . p.83

17 Ilustração da execução do alinhamento múltiplo em um segundo passo. p.84

18 Cluster central do GridUnesp. . . . . . . . . . . . . . . . . . . . . p. 89

19 Projeto KyaTera. . . . . . . . . . . . . . . . . . . . p. 90

20 Execução da construção da matriz de pontuação, com conjunto de 4 sequências de aminoácidos, com 200 aminoácidos cada. . . . . . . . . . . p. 93

21 Execução de todas as fases da ferramenta de alinhamento, com conjunto de 4 sequências de aminoácidos, com 200 aminoácidos cada. . . . . . . . p. 95

22 Execução da construção da matriz de pontuação, com um conjunto de 400 sequências de nucleotídeos, com 500 pares de bases cada. . . . . . . . p. 96

23 Execução de todas as fases da ferramenta de alinhamento, com conjunto de 400 sequências de nucleotídeos, com 500 pares de bases cada. . . . . . p. 97

24 Execução da construção da matriz de pontuação, com um conjunto de 3000 sequências de nucleotídeos, com 2000 pares de bases cada. . . . . . p. 97

25 Execução de todas as fases da ferramenta de alinhamento, com conjunto de 3000 sequências de nucleotídeos, com 2000 pares de bases cada. . . . . p. p.98

26 Execução da construção da matriz de pontuação, com um conjunto de 6000 sequências de nucleotídeos, com 10000 pares de bases cada. . . . . . p. 99

27 Execução de todas as fases da ferramenta de alinhamento, com conjunto de 6000 sequências de nucleotídeos, com 10000 pares de bases cada. . . . p. 99 
28 Execução da construção da matriz de pontuação, com um conjunto de 4000 sequências de nucleotídeos, com sequências de 300 a 6000 pares de base. . . . . . . . . . . . . . . . . . . p. 100

29 Execução de todas as fases da ferramenta de alinhamento, com conjunto de 4000 sequências de nucleotídeos, com sequências de 300 a 6000 pares de base. . . . . . . . . . . . . . . . . . . . p. 101

30 Construção da Árvore Guia - Colônias de Formigas (ACO) x Neigbohr

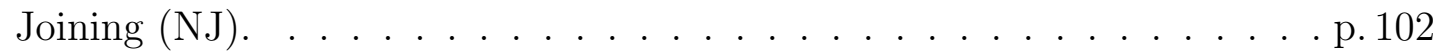

31 Fase de Alinhamento Múltiplo - Simulated Annealing Paralelo (SAP) x Alinhamento Múltiplo Sequencial (AMS). . . . . . . . . . . . . . . . . . p. 102 


\section{Lista de Tabelas}

1 Os vinte aminoácidos que são codificados.

2 Tabela comparativa com resultados de alguns programas de alinhamento múltiplo em relação à execução da ferramenta proposta em ambiente sequencial. . . . . . . . . . . . . . . . . . . . p. 104

3 Tabela comparativa com resultados de alguns programas de alinhamento múltiplo em relação à execução da ferramenta proposta em ambiente de grande porte. . . . . . . . . . . . . . . . p. 105

4 Tabela comparativa com resultados de alguns programas de alinhamento múltiplo em relação à execução da ferramenta proposta em ambiente de grande porte, com sequências de tamanhos equivalentes. . . . . . . . . p. 106

5 Tabela comparativa com resultados da execução da ferramenta proposta e do ClustalW-MPI, em ambiente de grande porte. . . . . . . . . . p. 107

6 Tabela comparativa com resultados da execução da ferramenta proposta e do ClustalW-MPI, em ambiente de grande porte, com sequências de tamanhos equivalentes. . . . . . . . . . . . . . . . p. 107 


\section{Sumário}

1 Introdução $\quad$ p. 16

1.1 Considerações Iniciais . . . . . . . . . . . . . . . . . . . . p. 16

1.2 Objetivos . . . . . . . . . . . . . . . . . . . 18

1.3 Motivações . . . . . . . . . . . . . . . . . . . p. 20

1.4 Metodologia . . . . . . . . . . . . . . . p. 21

1.5 Organização dos Capítulos . . . . . . . . . . . . . . . p. 22

2 Conceitos p. 24

2.1 Contexto Biológico . . . . . . . . . . . . . . . . p. 24

2.1.1 Organização Celular . . . . . . . . . . . . . . . p. 24

2.1.2 Macromoléculas Biológicas . . . . . . . . . . . p. 25

2.1.3 Filogenia e Padrões . . . . . . . . . . . . . . . . p. 27

2.2 Alinhamento de Sequências . . . . . . . . . . . . . . . p. 28

2.2.1 Algoritmo de Needleman-Wunsch . . . . . . . . . . . . . . . . p. 29

2.2.2 Algoritmo de Smith-Waterman . . . . . . . . . . . . . p. 31

2.2.3 Análise de Sequências em Bases de Dados . . . . . . . . . . . p. 34

2.2.4 Alinhamento Múltiplo Progressivo . . . . . . . . . . . . p. 35

2.3 Computação de Alto Desempenho . . . . . . . . . . . . . . . . . p. 36 
2.3.1 Clusters Computacionais . . . . . . . . . . . . . p. 37

2.3.2 Grades Computacionais . . . . . . . . . . . . p. 37

2.3.3 Interface de Passagem de Mensagem . . . . . . . . . . . . p. 40

2.4 Computação de Alto Desempenho em Bioinformática . . . . . . . . . . p. 40

2.5 Otimizações de Algoritmos em Bioinformática . . . . . . . . . . . . p. 43

2.5.1 Bacteria Foraging Optimization-BFO ........... p. 44

2.5 .2 Busca Tabu . . . . . . . . . . . . . . p. 46

2.5.3 Simulated Annealing . . . . . . . . . . . . . p. 47

2.5.4 Colônia de Formigas . . . . . . . . . . . . . . . p. 48

3 Ferramentas de Alinhamento Múltiplo de Sequências p. 50

3.1 Aplicações de Computação de Alto Desempenho em Bioinformática . . . p.50

3.2 Clustal Omega . . . . . . . . . . . . . . . . p. 52

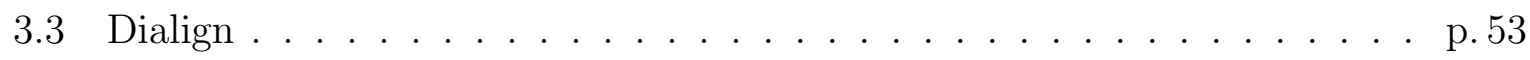

3.4 Saga . . . . . . . . . . . . . . . . . . . . . 55

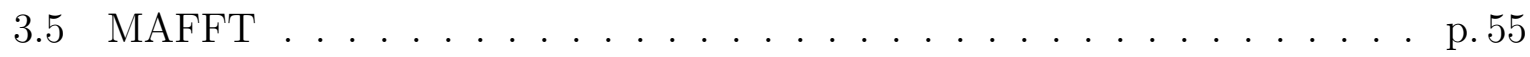

3.6 ClustalW-MPI . . . . . . . . . . . . . . . . . . p. 57

3.7 Alinhamento múltiplo paralelo e otimização através de colônia de formigas p. 57

3.8 Análise Comparativa . . . . . . . . . . . . . . . . . p. 58

4 Alinhamento Múltiplo de Sequências Aplicando Estratégias Híbri$\begin{array}{lr}\text { das e Paralelismo } & \text { p. } 60\end{array}$

4.1 Considerações Iniciais . . . . . . . . . . . . . . . . p. 60

4.2 Descrição da Proposta . . . . . . . . . . . . . . . . p. 61 
4.3 Construção da Matriz de Pontuação . . . . . . . . . . . . . . . . . . p. 62

4.3.1 Método de Particionamento . . . . . . . . . . . . . p. 62

4.3 .2 Estimativa de Pontuação . . . . . . . . . . . . . . . . p. 71

4.4 Aplicação de Técnicas de Otimização . . . . . . . . . . . . . . . p. 73

4.4 .1 Construção da Árvore Filogenética . . . . . . . . . . . . . . . . . p. 74

4.4.2 Alinhamento Múltiplo Propriamente Dito . . . . . . . . . . . . p.79

5 Implementação, testes e análises $\quad$ p. 86

5.1 Implementação . . . . . . . . . . . . . . . . p. 86

5.2 Infraestrutura utilizada . . . . . . . . . . . . . p. 87

5.2 .1 GridUnesp . . . . . . . . . . . . . . . . p. 87

5.2 .2 Ferramentas utilizadas . . . . . . . . . . . . . p. 91

5.2.3 Metodologia de testes . . . . . . . . . . . . . . p. 91

5.3 Testes de desempenho . . . . . . . . . . . . . . . . p. 92

5.3.1 Matriz de pontuação . . . . . . . . . . . . . . . p. 92

5.3 .2 Construção da árvore filogenética . . . . . . . . . . . . . . . p. 100

5.3 .3 Alinhamento múltiplo . . . . . . . . . . . . . . . . p. 101

5.4 Testes de qualidade . . . . . . . . . . . . . . . . . p. 103

6 Conclusões $\quad$ p. 109

6.1 Trabalhos Futuros . . . . . . . . . . . . . . p. 110

$\begin{array}{ll}\text { Referências } & \text { p. } 112\end{array}$ 


\section{Introdução}

Neste capítulo, serão realizadas as considerações iniciais sobre o presente trabalho, com intuito de apresentar os objetivos e motivações que levaram à sua proposição, bem como descrever a metodologia adotada para o seu desenvolvimento e, finalmente, apresentar a organização de seus capítulos.

\subsection{Considerações Iniciais}

O interesse pela área de computação aplicada à biologia difundiu-se muito nos últimos anos, especialmente pelas grandes massas de dados obtidas pelas análise experimentais [Díaz et al. 2014]. Várias áreas da biologia podem se beneficiar do uso da computação, no entanto, a genética mostrou-se como uma das principais, senão a principal beneficiada.

Avaliar as informações obtidas através de resultados gerados pelos sequenciadores automáticos, tornou-se um grande desafio para os profissionais de ciências biológicas envolvidos nesta área de pesquisa em genômica [Zhou et al. 2007]. Essas avaliações partem, principalmente, da ideia de promover o alinhamento de sequências de nucleotídeos e aminoácidos, com o intuito de fazer inferências sobre os resultados e buscar padrões possivelmente gerados.

A realização de uma análise não automática, ou manual, de todas as informações obtidas a partir de pesquisas experimentais, mostra-se totalmente inviável, especialmente pela dimensão dos conjuntos de informações [Liew, Yan e Yang 2005]. Assim, a Bioinformática destaca-se como a alternativa mais viável, de modo que recursos computacionais 
são aplicados de maneira coerente para solucionar problemas intrinsecamente biológicos [Edgar e Batzoglou 2006].

Desenvolveram-se inúmeras técnicas em Bioinformática para a execução de tarefas de alinhamentos de sequência e busca por padrões. As diversas técnicas de alinhamentos de sequências e busca por padrões desenvolvidas foram úteis durante anos. No entanto, com a evolução dos problemas encontrados pelos pesquisadores, a complexidade na forma de tratá-los também aumentou. Assim, a utilização de técnicas computacionais para o alinhamento múltiplo de sequências tornou-se uma necessidade [Needleman e Wunsch 1970, Wallace, Blackshields e Higgins 2005].

Apesar do uso de técnicas de alinhamento múltiplo de sequências, o número de sequências a serem analisadas continuou a crescer de maneira muito rápida, passando de algumas dezenas, para milhares de sequências e, em diversos casos, milhões. Dessa forma, necessitou-se de mais poder computacional para fazer essas análises, visto que o computador sequencial, até então utilizado, não supria mais as carências. Assim, a computação de alto desempenho tornou-se uma realidade na solução de problemas de Bioinformática [Schmidt 2011].

Os clusters e as grades computacionais são opções de ambientes de computação paralela e distribuída, e despontaram-se como uma alternativa para a execução de tarefas de Bioinformática. Em relação aos clusters, estes são composições mais homogêneas e, geralmente, operam de maneira dedicada em relação à oferta dos seus recursos [Buyya 1999]. As grades computacionais possuem a característica de serem ambientes heterogêneos, capazes de integrar diversos recursos computacionais, como unidades de processamento, memória e armazenamento, com diferentes velocidades de acesso, capacidades de trabalho e armazenamento de dados [Foster e Kesselman 1998]. Esses dois tipos de sistemas computacionais citados anteriormente são amplamente utilizados na execução de problemas de Bioinformática.

Embora esses sistemas computacionais paralelos e distribuídos possuam grande capa- 
cidade de processamento e armazenamento, a evolução da complexidade dos problemas biológicos encontra-se em franco crescimento. Dessa forma, mostra-se cada vez mais necessário associar-se outras técnicas à computação paralela e distribuída, de modo a resolver de maneira mais adequada, em um tempo hábil e com resultados cada vez mais precisos, os problemas existentes.

Uma alternativa bastante interessante é a aplicação de heurísticas agregadas a estas técnicas de computação paralela e distribuída. Como tratam-se de abordagens estocásticas, estas heurísticas podem ser modeladas para diversos tipos de problemas em Bioinformática [Lo 1988]. No entanto, deve-se entender de maneira clara a sua aplicação, para que a eficiência da heurística seja realmente a esperada e não degrade o desempenho do algoritmo, tampouco a qualidade dos resultados finais produzidos, em termos de significância biológica [Hamada e Asai 2012].

\subsection{Objetivos}

Destacam-se como objetivos, no presente trabalho, o desenvolvimento e a implementação de algoritmos paralelos de alinhamento múltiplo de sequências, em conjunto com técnicas de otimização de Colônia de Formigas (Ant Colony) e Simulated Annealing. A utilização dessas diversas técnicas agregadas, quais sejam, algoritmos paralelos, Colônias de Formigas e Simulated Annealing, tornam o ambiente de execução híbrido, garantindo uma melhora no desempenho, em termos de tempo de execução dos algoritmos, além de um refinamento na qualidade dos alinhamentos finais, tornando-os mais precisos e com maior significância biológica.

É importante ressaltar que a aplicação de todas as técnicas anteriormente citadas ocorre sobre o algoritmo de alinhamento múltiplo de sequências progressivo. Este algoritmo é, basicamente, dividido em três fases: a construção da matriz de pontuações, a geração da árvore filogenética (guia) e execução de um alinhamento múltiplo propriamente dito. A escolha por este tipo de algoritmo deve-se à sua ampla utilização em 
Bioinformática e à possibilidade da realização de melhorias em todas as suas fases.

O primeiro ponto almejado, neste trabalho, é a aplicação de paralelismo, visando melhorar o desempenho da primeira fase do algoritmo de alinhamento múltiplo. Essa evolução ocorre com a seguinte avaliação: a partir do tamanho do par de sequências, pode-se executar o cálculo da pontuação do par por completo, em uma unidade de processamento, ou particionar o par em trechos menores, que são executados em várias unidades de processamento. A expectativa de reduzir o tempo de processamento na primeira fase do algoritmo de alinhamento múltiplo de sequências progressivo e melhorar o nível de ocupação das unidades de processamento, é um atrativo para desenvolver esse mecanismo.

O segundo ponto a ser ressaltado, compõe-se da ideia do uso do algoritmo de otimização de colônia de formigas, que é uma heurística bioinspirada, baseada no comportamento das formigas e na sua distribuição de feromônio. Este tem por objetivo otimizar o processo de construção da árvore filogenética, que é a segunda fase do algoritmo de alinhamento múltiplo progressivo, visto que a estratégia de colônia de formigas é especialmente aplicável em processos de busca de caminho mínimo, que é o princípio da construção da árvore filogenética. Com isso, contribui-se para o aumento no ganho de desempenho do algoritmo múltiplo progressivo.

Finalmente, o terceiro ponto a ser apresentado, relaciona-se ao refinamento da solução final do alinhamento múltiplo. Como o algoritmo paralelo de alinhamento múltiplo progressivo trata-se de uma abordagem estocástica, a ideia é que a sua solução obtenha o máximo grau de otimalidade, permitindo resultados muito próximos dos obtidos com métodos determinísticos. No entanto, nem sempre isso é possível e, dessa maneira, pretende-se utilizar o algoritmo de Simulated Annealing para refinar a solução, realizandose diversas iterações do algoritmo, com intuito de aumentar o grau de precisão e significância da solução final. Apesar do algoritmo de Simulated Annealing ser um processo iterativo e custoso computacionalmente, ele foi implementado de forma paralela, melhorando o seu desempenho em termos de execução e aproveitando todos os recursos que os 
ambientes de computação paralela e distribuída oferecem, o que torna factível o seu uso.

Os três pontos principais elencados anteriormente, após uma vasta pesquisa realizada na literatura, destacaram-se por serem de características inovadoras. A sua utilização, em conjunto, de forma híbrida, para resolver problemas de algoritmos paralelos de alinhamento múltiplo, otimizando a operação do algoritmo e refinando o resultado final, não foi desenvolvida anteriormente.

Todas estratégias descritas nos parágrafos anteriores, quando da sua atuação em conjunto, visam auxiliar na geração de resultados para análise em processos de busca de similaridades e filogenia, que são duas vertentes de pesquisas muito relevantes no âmbito da Biologia Molecular e da Bioinformática.

\subsection{Motivações}

Os algoritmos de alinhamentos de biossequências possuem uma massiva utilização pelos pesquisadores que trabalham com as áreas de Genômica e Bioinformática. Os problemas apresentados por esses pesquisadores exigem, cada vez mais, uma grande capacidade de processamento para tratar a quantidade de dados que cresce diariamente. Com isso, aumenta também a necessidade por uma grande capacidade de armazenamento, para os inúmeros resultados obtidos. A utilização de processamento e armazenamento distribuídos, além de trazer benefícios na solução de problemas, aumenta a capacidade de integração entre as instituições de pesquisa que participam de projetos na área de Bioinformática e sistemas computacionais de alto desempenho.

Outro ponto a ser considerado, é que através de uma exaustiva pesquisa realizada na literatura sobre trabalhos relacionados com o tema envolvendo Bioinformática e computação paralela e distribuída, notou-se que a grande maioria dos trabalhos publicados enquadra-se em publicações recentes, ou seja, o que torna o trabalho relevante e atual. Em sua maioria, esses trabalhos tratam de temas que envolvem principalmente estratégias para a análise de dados genômicos em bases de dados ou abordagens mais gerais sobre Bi- 
oinformática, com o uso de sistemas computacionais paralelos e distribuídos. Isto torna o presente trabalho diferenciado e inovador, visto que a sua análise baseia-se em algoritmos desenvolvidos para execução de alinhamento múltiplo de sequências, sem acesso a bases de dados em tempo de execução. Além disso, a implementação de otimizações para esses algoritmos em ambientes de computação paralela e distribuída, utilizando Colônias de Formigas e Simulated Annealing, tudo de forma híbrida, resultando em redução de tempo de execução e aumento da qualidade dos resultados finais, não foi apresentada em outras propostas, até no limite das informações obtidas na revisão bibliográfica.

Finalmente, os estudos sobre buscas de similaridades e filogenia, a necessidade de operação com conjuntos de sequências muito grandes e a possibilidade de utilização de uma ferramenta de alinhamento múltiplo paralela e distribuída, agregando-se os processos de otimização em sua execução, também é interessante e corrobora para a motivação do presente trabalho.

\subsection{Metodologia}

A metodologia empregada, no presente projeto, baseou-se na ideia inicial de um levantamento bibliográfico relativo ao tema de algoritmos de alinhamento múltiplos aplicados em ambientes de computação paralela e distribuída. Esse levantamento contribuiu para o encaminhamento correto do tema da pesquisa, bem como para a definição do como tratar o problema de alinhamentos múltiplos nesses ambientes de computação de alto desempenho, para a distribuição de tarefas e otimizações, cuidando para o ineditismo do trabalho.

Primeiramente, projetou-se e desenvolveu-se a melhor forma de aplicar a paralelização na primeira fase do algoritmo de alinhamento múltiplo progressivo, com uma atenção para o comprimento das sequências. A forma de tomada de decisão para executar o par de sequências por completo na unidade de processamento, ou particioná-lo, foi desenvolvida nesta etapa. 
Posteriormente, passou-se para a fase de desenvolvimento das estratégias de particionamento das sequências e a sua implementação, aproveitando, ao máximo, os recursos dos sistemas computacionais paralelos e distribuídos, com o objetivo de reduzir a complexidade computacional dos algoritmos de alinhamento múltiplo.

Na sequência, desenvolveu-se o mecanismo de otimização para a construção da árvore guia, ou filogenética, através da heurística de Colônia de Formigas.

Finalmente, utilizou-se estratégias de otimização adicionais a esses algoritmos de alinhamento múltiplos, através da heurística de Simulated Annealing paralela, para realizar o refinamento dos alinhamentos finais produzidos.

Todos os testes foram realizados a partir da infraestrutura oferecida pelo GridUnesp, que conta com diversos nós espalhados pelos estado de São Paulo e nos clusters e computadores do Laboratório de Bioinformática, da Unesp em São José do Rio Preto. Durante a fase de testes, realizou-se novos ajustes a partir dos resultados obtidos.

As validações finais para verificar a qualidade dos alinhamentos produzidos e, consequentemente, se possuem sentido biológico, realizaram-se através da comparação com alinhamentos da página do BaliBase [Thompson et al. 2005]. Os dados contidos no BaliBase são alinhamentos de conjuntos de aminoácidos realizados manualmente, através do estudo estrutural da proteína. Isso garante que os alinhamentos do BaliBase sejam 100\% confiáveis e precisos. As comparações foram realizadas com o uso do software bali_score, que confronta o alinhamento obtido por qualquer ferramenta, com o alinhamento existente no BaliBase, apresentando o percentual de similaridade entre eles.

\subsection{Organização dos Capítulos}

O presente trabalho organiza-se da seguinte maneira: no capítulo 1 faz-se uma introdução sucinta sobre o estudo realizado, além de apresentação dos objetivos, motivações e metodologia de desenvolvimento do presente trabalho. No capítulo 2 apresentam-se todos 
os conceitos necessários para o entendimento do trabalho. No capítulo 3 são descritas algumas ferramentas para alinhamento múltiplo de sequências. No capítulo 4 descreve-se toda a fase de desenvolvimento do projeto, de seus algoritmos, das abordagens para as estratégias de otimização, engajando-se para a parte final do trabalho com a realização de testes. No capítulo 5 são apresentados os resultados obtidos com as execuções dos algoritmos e, finalmente, o capítulo 6 traz as conclusões sobre o presente trabalho, bem como a proposição de trabalhos futuros. 


\section{Conceitos}

Neste capítulo, são apresentados os conceitos fundamentais sobre Biologia Molecular, Bioinformática e, por fim, Computação de Alto Desempenho e Otimizações em Bioinformática.

\subsection{Contexto Biológico}

Dentro do contexto biológico, conceituações sobre organização celular, macromoléculas biológicas, filogenia e descrição de padrões em biossequências, são importantes para apresentar a Biologia Molecular.

\subsubsection{Organização Celular}

Ao se falar em organização celular, deve-se ter em mente a subdivisão em dois grupos, os eucariontes e os procariontes [Rubin et al. 2000, Whitman, Coleman e Wiebe 1998]. Os eucariontes são caracterizados pela existência de um envoltório nuclear e os procariontes não possuem este envoltório.

Como pode ser visto na figura 1 [Lemos, Aragão e Casanova 2003], dispõem-se os elementos que compõem uma célula [Watson e Crick 1953].

Do ponto de vista de estudo, o DNA, o RNA e as proteínas, destacam-se com um papel extremamente relevante, pois são três macromoléculas biológicas muito importantes para os seres vivos [Adams, Knowler e Leader 1992, Bajorath, Stenkamp e Aruffo 1993] 
Figura 1: Exemplo de Célula Animal.

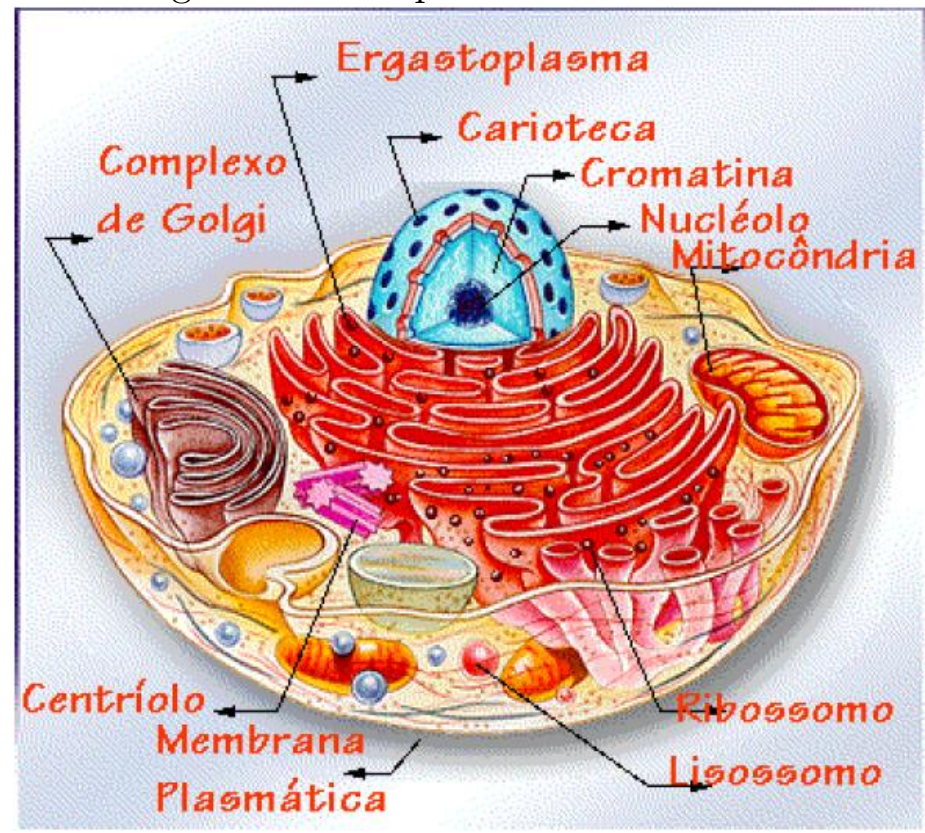

Fonte: Lemos, Casanova e Aragão (2003)

\subsubsection{Macromoléculas Biológicas}

As macromoléculas biológicas, pensando-se em Bioinformática, são, em geral, entendidas como sequências biológicas, ou biossequênicas [Eidhammer, Jonassen e Taylor 2000, Lemos, Aragão e Casanova 2003].

Classifica-se tanto as moléculas de DNA, como as de RNA, como cadeias de nucleotídeos. As proteínas, devido ao seus formadores serem os aminoácidos, são classificadas como cadeias de aminoácidos [Bajorath, Stenkamp e Aruffo 1993].

Na figura 2 [Zafalon 2009], pode-se observar o processo de transcrição e tradução, desde a molécula do DNA, até a formação da proteína [Celis et al. 2000].

Sobre o DNA, pode-se dizer que é composto por quatro bases nitrogenadas que são a Adenina (A), a Timina (T), a Citosina (C) e a Guanina (G). Além disso, essas bases se ligam, através de uma relação [Watson e Crick 1953], conforme pode ser visto na figura 3 [Zafalon 2009]. 
Figura 2: Processo de Transcrição e Tradução.

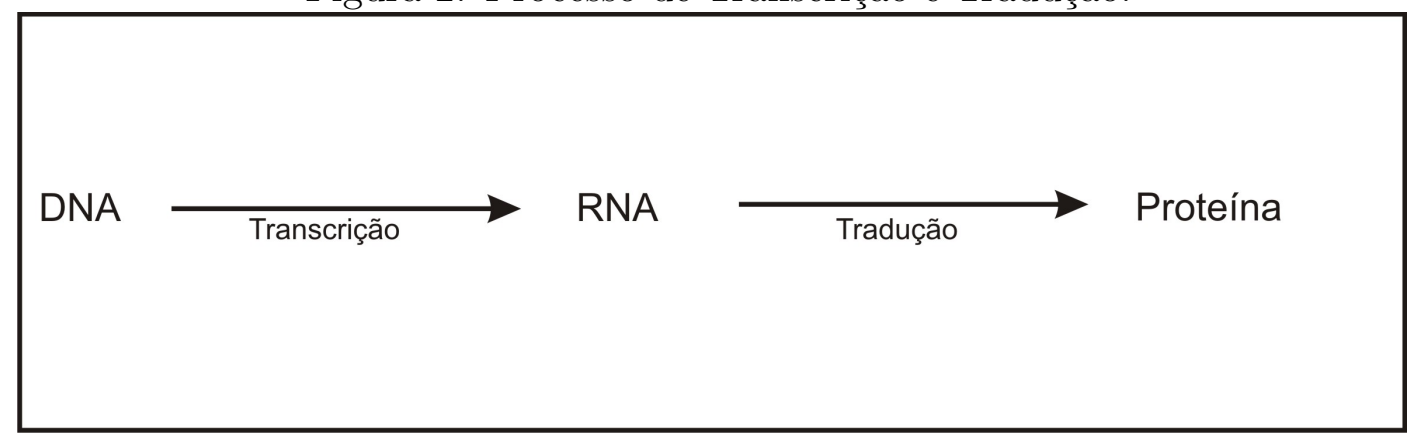

Fonte: Zafalon (2009)

Figura 3: Interligação entre as bases que compõem o DNA.

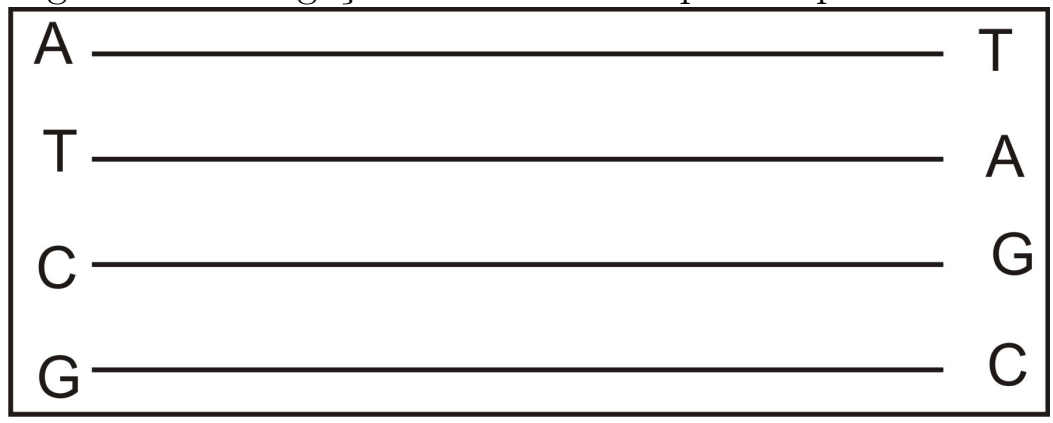

Fonte: Zafalon (2009) 
Para a formação das proteínas, existe a necessidade da codificação de aminoácidos. Esses aminoácidos fazem partem de um conjunto que pode ser visto na tabela 1 [Lemos e Casanova 2000].

Tabela 1: Os vinte aminoácidos que são codificados.

\begin{tabular}{ccc}
\hline Nome & Símbolo & Abreviação \\
\hline Glicina ou Glicocola & Gly, Gli & $\mathrm{G}$ \\
Alanina & Ala & $\mathrm{A}$ \\
Leucina & Leu & $\mathrm{L}$ \\
Valina & Val & $\mathrm{V}$ \\
Isoleucina & Ile & $\mathrm{I}$ \\
Prolina & Pro & $\mathrm{P}$ \\
Fenilalanina & Phe ou Fen & $\mathrm{F}$ \\
Serina & Ser & $\mathrm{S}$ \\
Treonina & Thr, The & $\mathrm{T}$ \\
Cisteina & Cys, Cis & $\mathrm{C}$ \\
Tirosina & Tyr, Tir & $\mathrm{Y}$ \\
Asparagina & Asn & $\mathrm{N}$ \\
Glutamina & Gln & $\mathrm{Q}$ \\
Aspartato ou Ácido aspártico & Asp & $\mathrm{D}$ \\
Glutamato ou Ácido glutâmico & Glu & $\mathrm{E}$ \\
Arginina & Arg & $\mathrm{R}$ \\
Lisina & Lys, Lis & $\mathrm{K}$ \\
Histidina & His & $\mathrm{H}$ \\
Triptofano & Trp, Tri & $\mathrm{W}$ \\
Metionina & Met & $\mathrm{M}$ \\
\hline
\end{tabular}

Fonte: Lemos e Casanova (2000)

\subsubsection{Filogenia e Padrões}

Os estudos desenvolvidos no âmbito da biologia celular e molecular podem explicar uma série de fatores que se propagam no decorrer das gerações de seres vivos.

A filogenia e a análise de padrões são vertentes de estudos que buscam identificar, respectivamente, o caminho de um processo evolucionário e as características da evolução que predominaram com o passar do tempo [Gould 1985].

Tanto a filogenia, quanto a descoberta de padrões, tornaram-se tarefas muito custosas, atualmente, especialmente devido às grandes massas de dados geradas, relativas aos 
diversos organismos. O uso de computação para auxiliar na realização dessas duas tarefas tornou-se imprescindível.

Diversas abordagens algorítmicas foram desenvolvidas no decorrer dos anos, com uma ampla diversidade de aplicações. No entanto, a filogenia e a descoberta de padrões receberam uma atenção especial, com a utilização de técnicas de alinhamento de sequências [Brazma et al. 1998, Gouy, Guindon e Gascuel 2010].

\section{$2.2 \quad$ Alinhamento de Sequências}

Conforme descrito anteriormente, para a realização de inferências sobre processos filogenéticos e o reconhecimento de padrões, o uso de técnicas de alinhamento de sequências é largamente difundido [Needleman e Wunsch 1970]. A partir dos alinhamentos de sequências facilita-se a identificação de regiões conservadas e de regiões que sofreram mutação no processo evolutivo. Nas regiões conservadas, que são as que se repetem, realiza-se a análise de coincidências, e nas regiões de mutação, buscam-se as divergências. Em geral, os pontos encontrados a partir destas análise possuem alguma relevância.

Um alinhamento, simplificadamente, é uma estratégia de reposicionamento dos elementos componentes de um conjunto de sequências biológicas, para que se consiga encontrar o máximo de similaridades entre estas sequências. Quanto mais similaridades são encontradas, maior é a pontuação obtida pelo alinhamento. Cada coincidência entre as bases, pensando-se em DNA, e entre os aminoácidos, sob a ótica das proteínas, é chamada de match. Os espaços eventualmente inseridos no processo de alinhamento são denominados gaps.

A implementação desses algoritmos iniciou-se com o uso da programação dinâmica [Rouchka 2006]. Esta, trata-se de uma técnica de alinhamento exata, produzindo o melhor resultado final de um alinhamento possível. Duas vertentes dessa técnica são muito utilizadas, o algoritmo de Needleman-Wunsch [Needleman e Wunsch 1970], para alinhamentos globais, e o algoritmo de Smith-Waterman [Smith e Waterman 1981], para alinhamentos 
locais.

\subsubsection{Algoritmo de Needleman-Wunsch}

Os alinhamentos globais consideram em uma análise das sequências como um todo, independente se essas sequências sejam de nucleotídeos ou de aminoácidos, procurando por um máximo de similaridade entre elas. Com isso, o alinhamento global tenta identificar sequências muito parecidas, não se preocupando com pontos em particular. O algoritmo de Needleman-Wunsch [Needleman e Wunsch 1970], para alinhamento global de sequências, usa a estratégia de programação dinâmica para realizar a tarefa e trata-se de um dos algoritmos mais conhecidos para alinhamentos de pares de sequências. Este algoritmo garante a obtenção do resultado exato do alinhamento, ou seja, o melhor resultado, pelo fato de ser um algoritmo determinístico [Gusfield 1997]. Basicamente, ele realiza o alinhamento de um par de sequências, a partir da construção de uma matriz de valores, e posteriormente, faz uma escalada em caminho reverso nessa matriz (backtracking), para obter o melhor alinhamento.

Primeiramente, o algoritmo deve construir a matriz de valores. Conforme apresenta-se na figura 4 [Cristino], é necessário começar pelo preenchimento das células da linha 0 e coluna 0 , em que são utilizados os valores de gap como base. Nesse exemplo, considera-se o gap com valor -4 , o acerto (match) com valor +5 e o erro (mismatch) com valor igual a -3. Quanto menor o valor, mais penalizada é aquela característica. As duas sequências adotadas para o exemplo são: Seq 1: GAATTCAGTTA e Seq 2: GGATCGA.

O preenchimento da primeira célula, linha 0 e da coluna 0 , dá-se pela seguinte regra:

$$
\begin{aligned}
& S_{0, j}=g a p * j \\
& S_{i, 0}=g a p * i
\end{aligned}
$$

A partir desses primeiros itens preenchidos, as demais células da matriz são preenchidas, conforme apresenta-se graficamente na figura 5 [Cristino] e obedecendo a regra, a seguir: 
Figura 4: Início da construção da matriz de valores para o algoritmo de NeedlemanWunsch.
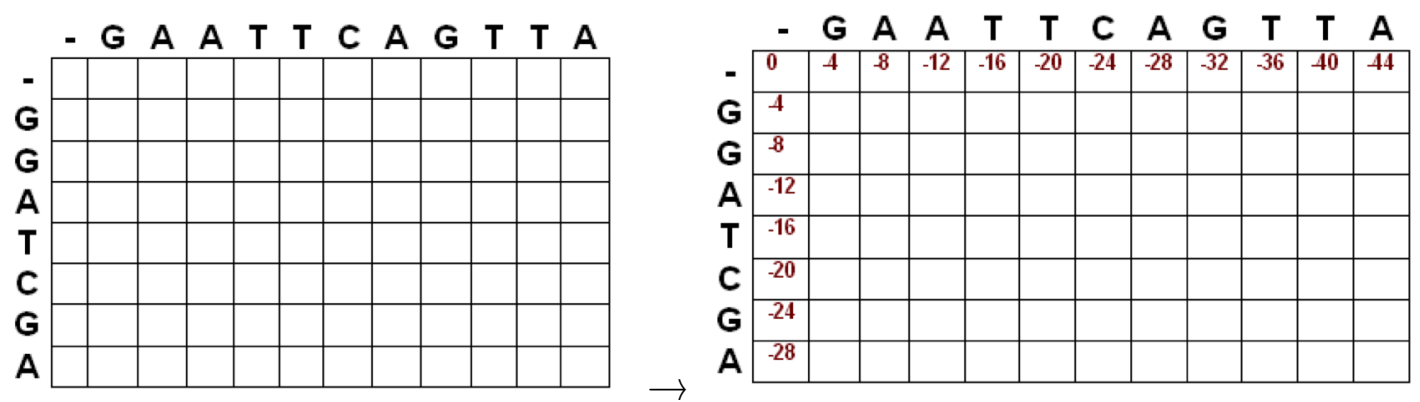

Fonte: Cristino (2012)

$$
S_{i, j}=\operatorname{MAX}\left\{\begin{array}{l}
S_{i-1, j-1}+\text { match } / \text { mismatch } \\
S_{i, j-1}+\text { gap } \\
S_{i-1, j}+\text { gap }
\end{array}\right.
$$

Figura 5: Processo de construção da matriz de valores para o algoritmo de NeedlemanWunsch.
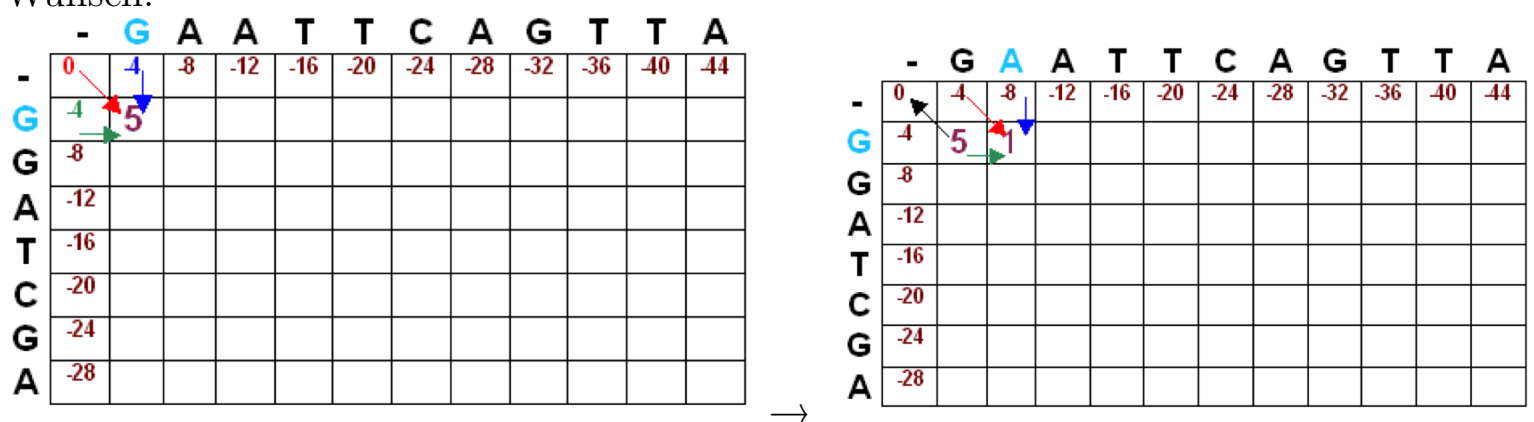

Fonte: Cristino (2012)

Na figura 6 [Cristino], apresenta-se, à esquerda, a matriz de valores totalmente preenchida a partir das regras anteriormente descritas e, à direita, a execução do mecanismo de backtracking, que parte do elemento de maior valor, no canto inferior direito da matriz, e continua o percurso ascendente, escolhendo entre o maior valor em linha, coluna ou diagonal. Além disso, logo abaixo dessa matriz à direita, encontra-se o alinhamento ótimo obtido. 
Figura 6: A matriz de valores finalizada para o algoritmo de Needleman-Wunsch, à esquerda, e a realização do backtracking, com o alinhamento final, à direita.
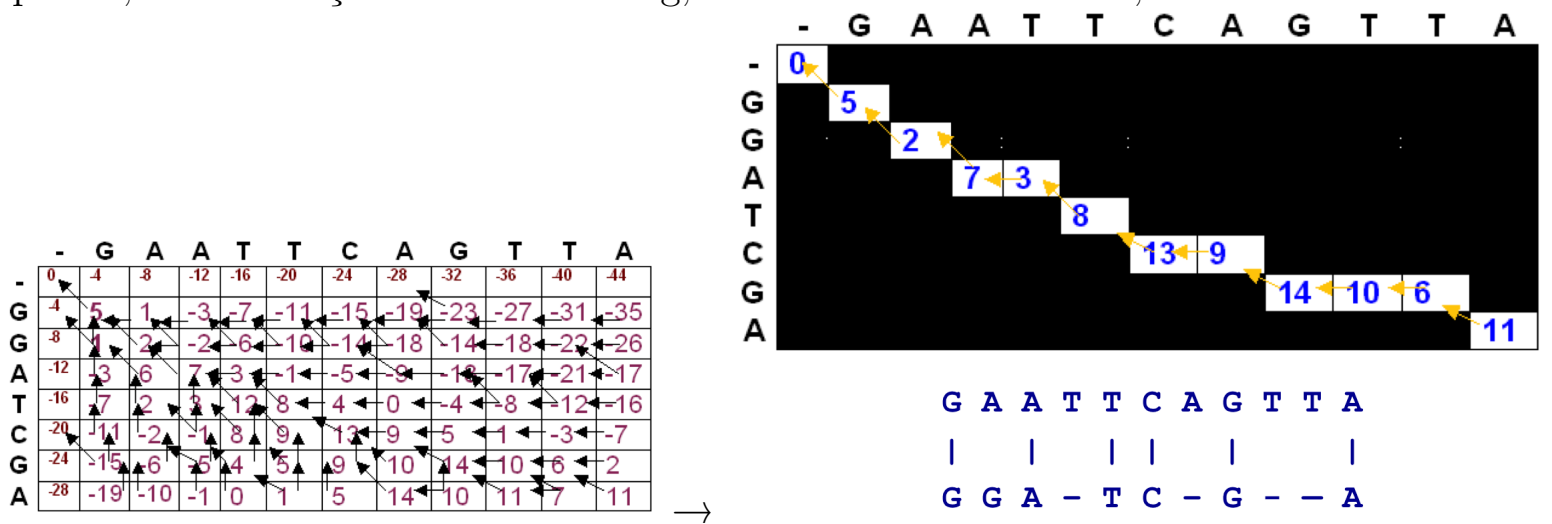

Fonte: Cristino (2012)

\subsubsection{Algoritmo de Smith-Waterman}

O alinhamento local, contrariamente ao alinhamento global, preocupa-se em encontrar pontos específicos de similaridade dentro das sequências. Esses pontos podem representar características que, eventualmente, serão úteis para as análises feitas pelos biólogos. Por exemplo, em um genoma de um vírus, se os pesquisadores tiverem conhecimento de uma região em particular que corresponda à sua capacidade de mutação, eles podem tentar desenvolver um determinado inibidor para esse vírus. A partir do momento em que essas regiões possuem algum sentido biológico de fato, elas passam a ser classificadas como hot spots (pontos quentes).

Para o alinhamento local, um dos algoritmos mais utilizados e que também garante a obtenção do resultado exato, é o de Smith-Waterman [Smith e Waterman 1981]. Este algoritmo é baseado no algoritmo de Needleman-Wunsch [Needleman e Wunsch 1970], portanto, adotando, também, o uso de programação dinâmica. A principal diferença é que as células da matriz de valores, com pontuação negativa, têm seus valores definidos como zero, para tornar os alinhamentos locais mais visíveis. O cálculo dos valores da matriz obedece a seguinte regra: 


$$
\mathrm{H}_{i, j}=\operatorname{MAX}\left\{\begin{array}{l}
\mathrm{H}_{i-1, j-1}+\text { match/mismatch } \\
\mathrm{H}_{i, j-1}+\mathrm{gap} \\
\mathrm{H}_{i-1, j}+\mathrm{gap} \\
0
\end{array}\right.
$$

Considerando os mesmos valores de gap, match e mismatch, $-4,+5$ e -3 , respectivamente, apresenta-se, na figura 7[Cristino], a construção da matriz de valores:

Figura 7: Processo de construção da matriz de valores para o algoritmo Smith-Waterman.
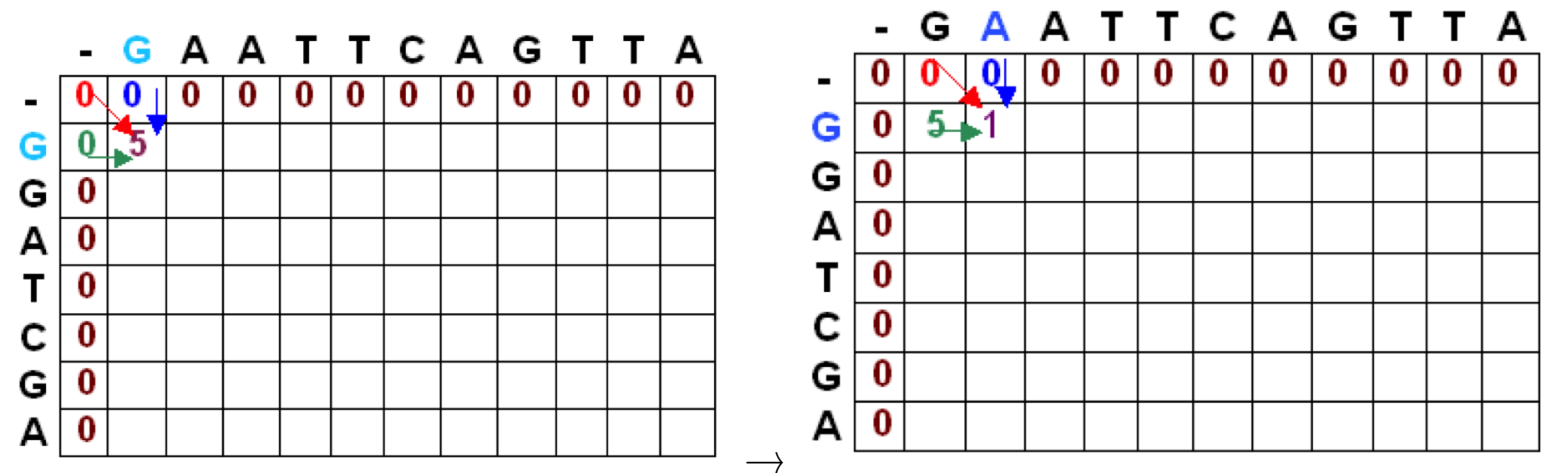

Fonte: Cristino (2012)

O backtracking inicia-se na célula da matriz de pontuação mais alta e continua até que uma célula com pontuação zero seja encontrada, gerando o alinhamento com maior pontuação local. Na figura 8 [Cristino], apresenta-se a matriz para o algoritmo SmithWaterman construída com todos os seus valores, bem como a realização do backtracking. Vale notar a não existência de valores negativos.

Finalmente, na figura 9[Smith e Waterman 1981], apresenta-se os dois alinhamentos locais ótimos obtidos com a execução do algoritmo Smith-Waterman, para o mesmo par de sequências utilizado no algoritmo de alinhamento global, Seq 1: GAATTCAGTTA e Seq 2: GGATCGA: 
Figura 8: A matriz de valores finalizada para o algoritmo Smith-Waterman, à esquerda, e a realização do backtracking, à direita.
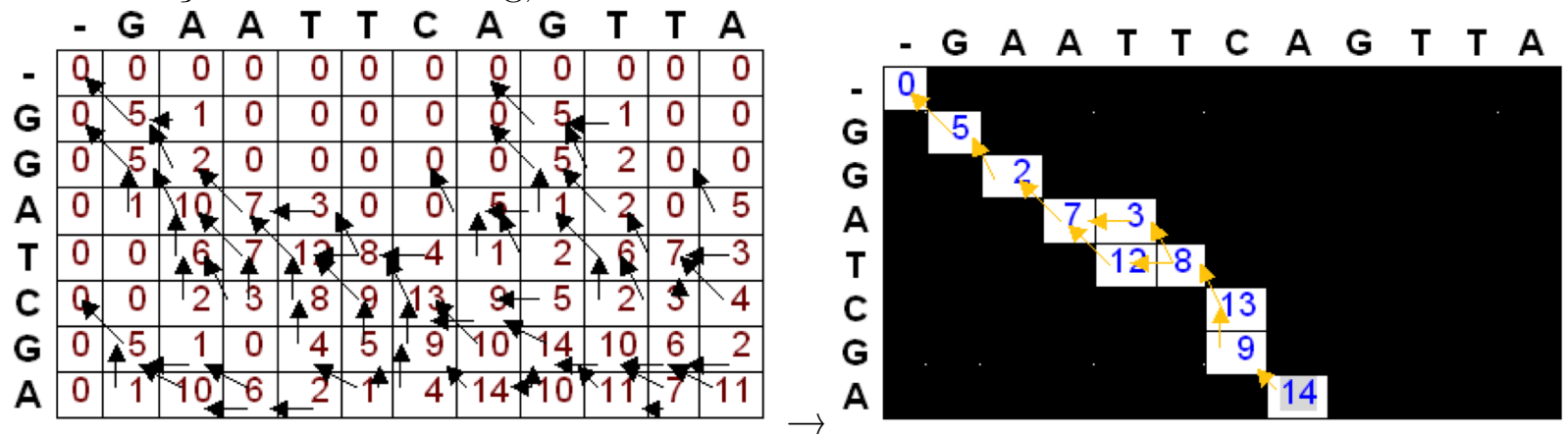

Fonte: Cristino (2012)

Figura 9: Alinhamentos locais ótimos.

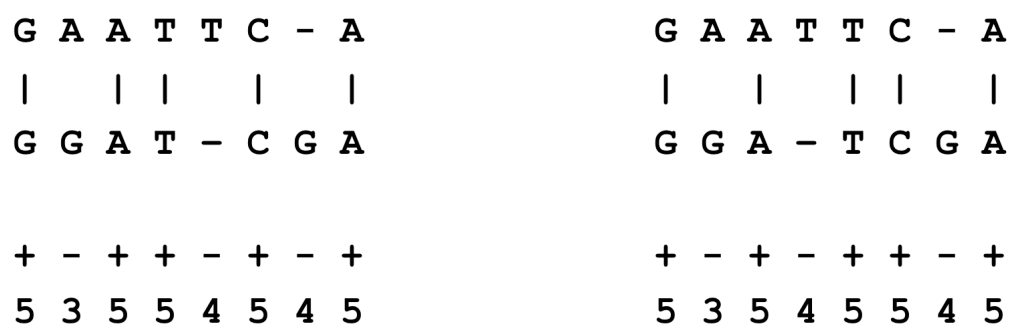

Fonte: Smith and Waterman (1981) 


\subsubsection{Análise de Sequências em Bases de Dados}

Com o crescimento avassalador do número de sequências armazenadas nas bases de dados, especialmente as bases on-line, procurou-se algumas alternativas em relação aos algoritmos de programação dinâmica [Doolittle 1990, Murty e Kabadi 1987].

Os algoritmos de programação dinâmica comportam-se adequadamente para a execução com conjuntos de no máximo duas sequências [Needleman e Wunsch 1970]. Depois desse limite, a complexidade computacional do algoritmo, que é $\mathrm{O}\left(\mathrm{n}^{2}\right)$, torna a sua execução inviável, excluindo-se a possibilidade da utilização de métodos exatos.

A partir da impossibilidade do uso de métodos exatos, desenvolveram-se alguns métodos heurísticos. Dentre os mais utilizados, estão o FAST [Lipman e Pearson 1985, Pearson e Lipman 1988], o BLAST [Altschul et al. 1990], e o BLAT [Kent 2002].

O FAST pode operar tanto com sequências de nucleotídeos, quanto aminoácidos, com a intenção de encontrar grupos de trechos que se repetem (motifs) entre as sequências analisadas. O FAST possui diversas variantes, como o FASTN, para a operação específica com nucleotídeos, o FASTP, para a operação com proteínas e o LFASTA, para encontrar alinhamentos locais [Lipman e Pearson 1985, Pearson e Lipman 1988].

Um outro método largamente utilizado é o BLAST. Este foi desenvolvido para detectar conjuntos de baixa similaridade entre as sequências. O BLAST também possui variantes, como o BLASTN, para operar apenas com nucleotídeos e o BLASTP para utilização apenas com sequências de aminoácidos [Altschul et al. 1990].

Por fim, o BLAT é utilizado para realizar alinhamentos de mRNA e DNA e para o cruzamento de espécies de proteínas em vertebrados. Trata-se de uma ferramenta eficiente para proceder estas operações, pois o seu método de análise parte de uma estrutura de indexação baseada na não sobreposição dos K-mers nos genomas, o que facilita a identificação de regiões homólogas nas sequências consultadas [Kent 2002]. 


\subsubsection{Alinhamento Múltiplo Progressivo}

Com a limitação dos algoritmos de programação dinâmica empreendida por sua grande complexidade computacional, desenvolver uma alternativa a esta abordagem tornou-se uma necessidade [Mehlhorn 1984]. Com isso, surgiram os algoritmos de alinhamento múltiplo de sequências, cuja ideia é a possibilidade de se trabalhar com mais de duas sequências simultaneamente.

Ao se utilizar um algoritmo de alinhamento múltiplo de sequências, passa-se de uma abordagem exata, até então presente nos algoritmos de programação dinâmica, para uma abordagem heurística. Nesta abordagem, introduzem-se fatores probabilísticos para a produção dos resultados em tempo hábil.

Existem diversas variantes dos algoritmos de alinhamento múltiplo. No entanto, entre as mais utilizadas, a abordagem de alinhamento múltiplo progressivo se destaca. Os bons resultados obtidos com esta abordagem, tornaram-na muito interessante, especialmente sob o ponto de vista de sempre existir um resultado para qualquer entrada que seja [Feng e Doolittle 1987].

Os algoritmos de alinhamento múltiplo progressivos são divididos em três fases bem definidas [Nei e Saito 1987, Wallace, Blackshields e Higgins 2005]:

1. Alinhamento par-a-ar e construção da matriz de pontuação: nesta fase, executa-se o alinhamento par-a-par de todas as sequências pertencentes ao conjunto. As pontuações obtidas nesses alinhamentos são inseridas em uma matriz.

2. Construção da árvore filogenética (guia): depois de obtidas as pontuações na fase anterior, essas pontuações são alocadas em uma estrutura de dados do tipo árvore, de modo que pares com pontuações mais próximas fiquem mais próximos na árvore.

3. Alinhamento múltiplo propriamente dito: considerando-se os pares de sequências que estão mais próximos na árvore filogenética, existe um realinhamento das 
sequências. Cada nova sequências inserida é realinhada com o grupo de sequências anteriormente alinhado.

No entanto, os algoritmos de alinhamento múltiplo, mesmo os progressivos, começaram a sofrer com o aumento do número de sequências a serem avaliadas e, para isso, associaram-se a técnicas de computação de alto desempenho para auxiliá-los

\subsection{Computação de Alto Desempenho}

A computação de alto desempenho enquadra-se como uma estratégia auxiliar aos algoritmos de alinhamento múltiplo de sequência, de forma que estes consigam operar com conjuntos de sequências cada vez maiores [Mehlhorn 1984, Zomaya, Ercal e Olariu 2001].

Basicamente, para se obter ganhos de desempenho na execução dos algoritmos de alinhamento múltiplo, procura-se paralelizar, sempre que possível, trechos computacionalmente custosos que os compõem. Analisando-se o algoritmo de alinhamento múltiplo progressivo, citado anteriormente, a sua primeira fase, que á construção da matriz de pontuação, é muito custosa computacionalmente. Portanto, esta é uma fase potencial para a paralelização, especialmente porque realiza tarefas de forma independente.

Claro que a paralelização deve contribuir, primeiramente, para a evolução do desempenho do algoritmo, em termos de tempo de execução. No entanto, não é aceitável que, com a evolução de desempenho, a qualidade final dos resultados seja degradada. Portanto, este é um cuidado frequente que deve acontecer [Zomaya, Ercal e Olariu 2001]. Isto recai em um problema, em que nem todos os trechos podem ser paralelizados com garantias de qualidade.

Em Bioinformática, existem dois ambientes amplamente utilizados para execuções desses algoritmos paralelos de alinhamento múltiplo, que são os clusters e as grades computacionais [Buyya 1999, Chai, Gao e Panda 2007, Tan e Strazdins 2002]. Nas seções 2.3.1 e 2.3.2 a seguir, descrevem-se esses dois ambientes. Vale ressaltar que ambos os ambientes 
também são utilizados para outros tipos de aplicações que demandam grande capacidade de processamento, como simulações meteorológicas, prospecção petrolífera, física de altas energias, desenho de drogas, entre outras, e não apenas Bioinformática.

\subsubsection{Clusters Computacionais}

Em um ambiente do tipo cluster, a alocação de recursos é efetuada por domínio administrativo centralizado, sendo desnecessária a segurança do processo e do recurso, caso a rede de interconexão (intracluster) seja desacoplada da rede de acesso externo. Além disso, este tipo de ambiente pode se beneficiar de protocolos de comunicação mais eficientes entre suas unidades de processamento, pois como a rede de interconexão pertence ao mesmo domínio administrativo, o recurso é controlado [Buyya 1999].

Uma abordagem com um cluster possui alta escalabilidade, pois tarefas de inclusão ou exclusão de nós escravos não exigem que sejam feitas modificações no ambiente. As inserções ou remoções podem ser realizadas de forma isolada, partindo do nó mestre, por meio da execução de algum comando específico do software escolhido. No entanto, um fator limitante, em uma abordagem com clusters, pode ser o número de nós, que, em geral, não é tão grande [Buyya 1999].

\subsubsection{Grades Computacionais}

As soluções computacionais de alto desempenho utilizando clusters de computadores possuem um papel importante dentro dos diversos campos em que elas podem ser aplicadas. No entanto, uma série de entraves de ordem técnico-financeira acabam, muitas vezes, inviabilizando a expansão desses conjuntos.

Em relação ao ponto de vista financeiro, a rápida obsolescência do hardware presente nesses clusters torna as substituições, as atualizações, ou até mesmo a compra de mais equipamentos do mesmo tipo, muito caras, quando ainda se encontram dispositivos equivalentes. Com isso, a ideia de homogeneidade, que, em geral, dentro do ambiente 
de cluster é utilizada como um princípio interessante, pois garante a mesma capacidade de trabalho para cada nó, é esquecida, tornando esse ambiente heterogêneo e ineficaz, dependendo do tipo de tarefa a ser executada. No que tange o ponto de vista técnico, o crescimento constante da complexidade e dimensão dos problemas a serem resolvidos computacionalmente e a possibilidade da exploração de diversos recursos computacionais ociosos, em diversos conjuntos de computadores interligados em rede, colaboraram para que o desenvolvimento e a utilização de ambientes de grades computacionais recebessem uma atenção especial.

Uma grade computacional é uma infraestrutura de hardware e software, que provê um acesso seguro, consistente, pervasivo e pouco custoso, a sistemas computacionais de grande capacidade [Foster e Kesselman 1998]. Naturalmente, é um ambiente heterogêneo, que permite que equipamentos de diferentes tipos, configurações e até com diferentes sistemas operacionais, sejam capazes de interagir para realizar uma carga de processamento em comum [Fox e Gannon 2001, Skillicorn 2002].

A questão da infraestrutura para a grade computacional relaciona-se a prover uma larga escala de recursos compartilhados, como ciclos de computação, dados [Skillicorn 2002]. Esse compartilhamento depende da infraestrutura, principalmente dos mecanismos de interconexão, do monitoramento e controle dos resultados [Karonis, Toonen e Foster 2003].

Além de uma boa infraestrutura, a realização das operações em um ambiente com garantias de serviço é o primeiro ponto de fundamental importância. Os usuários desses grandes sistemas computacionais almejam um sistema que lhes garanta bons níveis de desempenho para os diversos componentes que constituem a grade computacional. As características de desempenho que interessam podem variar de aplicação para aplicação e são, por exemplo, largura de banda de rede de comunicação, a latência na transferência dos dados, o poder computacional, os serviços de software oferecidos, a confiabilidade, entre outros [Foster et al. 1998]. Estes itens podem colaborar para obtenção de um bom desempenho em uma grade computacional [Goux et al. 2001]. 
Com essa garantia de serviço assumida, a consistência dos serviços desponta como o segundo ponto de fundamental importância, principalmente, através de serviços padronizados, interfaces de acesso padronizadas e operações que também obedeçam padrões. Dentro de ambientes altamente heterogêneos, como são as grades computacionais, essa padronização apresenta-se como um grande desafio, pois para realizá-la, provavelmente, as características do alto desempenho são comprometidas [Buyya 1999, Foster e Kesselman 1998] e sem os padrões, o desenvolvimento de aplicações, o acesso e uso pervasivo são impraticáveis [Hingne et al. 2003] .

O acesso pervasivo, que é também um ponto fundamental a ser considerado na concepção de uma grade computacional, permite que se possa contar com serviços sempre disponíveis, independente do ambiente em que eles sejam executados. É importante deixar claro que a pervasividade não garante que os recursos poderão ser acessados a partir de qualquer lugar. Para que isso aconteça, é necessário que se tenha um ambiente de grade computacional para suportá-los [Foster e Kesselman 1998, Hingne et al. 2003].

Uma característica ainda não citada, porém que pode ser inferida a partir das características apresentadas, é a alta dispersão geográfica evidenciada nos ambientes de grade. Essa característica relaciona-se à escala que uma grade pode alcançar, partindo desde escalas locais, até o nível global, em que existem diversos serviços agregados e que se encontram em diversas partes do planeta [Cirne e Santos-Neto 2005, Skillicorn 2002]. Um fator importante acerca desse ponto é a realização de uma análise bem elaborada sobre os problemas de latência intrínsecos às aplicações que possuem os seus recursos separados por grandes distâncias geográficas. Isso, muitas vezes, dependendo da condição na qual as redes de interconexão se encontram e do tipo de atraso suportado pela aplicação, inviabiliza a utilização de ambientes grade [Czajkowski, Foster e Kesselman 1999, Foster e Karonis 1998].

Todas as características citadas anteriormente, quando combinadas, tornam importante o papel que os ambientes de grade exercem, criando-se uma variante para o uso da computação em aplicações que necessitam de muito poder computacional. Com 
isso, o desenvolvimento de ferramentas computacionais, para auxiliar em diversas tarefas do mundo real, passou a ser amplamente disseminado nas mais diversas áreas [Caminero, Carrión e Caminero 2006, Foster, Kesselman e Tuecke 2001].

\subsubsection{Interface de Passagem de Mensagem}

Quando se faz uso de sistemas computacionais paralelos e distribuídos, é quase que automática a ideia de que os elementos que compõem estes sistemas vão, em algum momento, comunicar-se.

Sabe-se que, em nível de hardware, há a necessidade de um suporte de uma rede de computadores. No entanto, quando se pensa em nível de software, que nesse caso é representado pela aplicação que executa sobre um sistema operacional, é necessário o uso de bibliotecas de comunicação.

Uma das bibliotecas mais utilizadas, especialmente pelo seu excelente desempenho nos processos de comunicação, é a biblioteca de Interface de Passagem de Mensagem, também chamada de MPI (Message Passing Interface) [Pacheco 1997]. A gama de funções que o MPI oferece permitiu que muitas tarefas, que até então eram inviáveis de serem paralelizadas, sem um mecanismo de comunicação eficiente, pudessem ser concretizadas. Em geral, tanto ambientes de clusters, como grades, possuem suporte para esta biblioteca.

\subsection{Computação de Alto Desempenho em Bioinfor- mática}

Conforme apresentado nas seções anteriores, o uso de sistemas computacionais de alto desempenho para a solução de problemas, nas mais diversas áreas de aplicação, tem se difundido amplamente, especialmente devido ao aumento da complexidade dos problemas a serem resolvidos e à expansão acentuada da quantidade de informações a serem processadas. Todas essas tarefas são requeridas em períodos cada vez mais curtos de tempo e com a necessidade de uma precisão cada vez maior dos resultados, o que exige mais 
recursos computacionais para esse refinamento.

Dentre as áreas que exploram o uso de grades computacionais para solucionar os seus diversos problemas, pode-se citar, notadamente: Energia [Lee e Chen 2002], Física de Partículas [Segal 2000], Telecomunicações [Baker, Buyya e Laforenza 2002] e, finalmente, Bioinformática [Psomopoulos e Mitkas 2010], cuja abordagem, no presente trabalho, encontra-se centrada, principalmente, no que se relaciona ao desenvolvimento de estratégias para alinhamentos múltiplos de biossequências.

Os mais diversos problemas existentes, dentro da Bioinformática, enquadram-se perfeitamente com as necessidades de se possuir alto poder de processamento para tratar uma infinidade de combinações, com a finalidade de se realizar as análises de conjuntos de biossequências e as inferências relativas a eles. O uso de clusters homogêneos e dedicados, para o processamento de dados em Bioinformática, mostrou-se como uma abordagem interessante, atendendo, inicialmente, às necessidades, com um bom custo/desempenho para a época em que foram concebidos [Sun et al. 2007].

Com o passar dos anos, houve a evolução das estratégias para desenvolvimento de processamento paralelo e distribuído, além do aproveitamento de recursos ociosos. Dessa forma, melhorias e otimizações na construção de sistemas dedicados, como os clusters para o processamento dessas informações biológicas, foram necessárias, principalmente devido à quantidade de dados que cresceu de maneira bastante acentuada. O processamento de uma massa de dados com tamanho razoável, com a possibilidade de se realizar algumas inferências sobre esses dados pós-processados, demandou um investimento cada vez mais alto para a construção de clusters sempre mais poderosos [Krieger e Vriend 2002]. Tenta-se agregar a esses clusters, quando possível, a ideia de mecanismos colaborativos, aproveitando-se de diversos recursos computacionais disponíveis e/ou subutilizados nos centros de pesquisas e universidades. Esta é uma abordagem bastante interessante e que sofreu um grande crescimento e difusão nos últimos anos [Andrade et al. 2006, Krieger e Vriend 2002, Stockinger et al. 2006]. 
Em computação científica, a computação de alto desempenho, em geral, é aplicada em três contextos bem definidos de demandas computacionais: computação distribuída de tarefas, computação de alta vazão e computação intensiva de dados. A Bioinformática, como uma área pertencente à computação científica, enquadra-se na classe de demandas para computação intensiva de dados. Na classe de problemas de dados intensivos, as áreas de armazenamento de dados, de processamento de dados e de análise de dados não estão sempre no mesmo local. Na solução de problemas deste tipo, o primeiro fator de complicação e, talvez, o mais caótico, é a geração de uma alta demanda de tráfego de dados, o que consome um tempo elevado para a realização dessas operações, mesmo utilizando um computador de alto desempenho. Dessa maneira, a implementação de mecanismos de comunicação eficientes é capaz de tratar desses problemas com os dados, de maneira bastante eficiente, com a oferta de alta demanda de recursos úteis, adequados às necessidades dos dados [Zhu et al. 2006].

O objetivo principal das aplicações em Bioinformática, no que tange à escolha e ao uso de ambientes computacionais de alto desempenho, é a possibilidade de agrupar sistemas de computação de larga escala e dispositivos de armazenamento de alta capacidade, com a finalidade de prover serviços com características de supercomputação. Estas aplicações, em Bioinformática, são aperfeiçoadas com novas funcionalidades a cada nova geração de problemas, os quais aumentam em um ritmo bastante acelerado. Assim, força-se uma melhoria na qualidade dos serviços e da utilização dos recursos oferecidos pelo sistemas computacionais de alto desempenho, principalmente no que se relaciona ao balanceamento de carga, que é um dos fatores mais importantes, quando o ambiente está em operação.

O processamento das aplicações em Bioinformática requer o uso de muitos recursos e, consequentemente, um gerenciamento que proporcione as suas integrações, garantindo que não haverá falta de oferecimento de tais recursos. A ausência da construção de uma infraestrutura de gerenciamento de recursos, no próprio local em que eles se encontram disponíveis, torna a solução dos problemas de Bioinformática praticamente intratáveis, devido à sua escala. Portanto, dois fatores importantes a se considerar no momento do 
desenvolvimento de uma solução em sistema computacionais de alto desempenho, especialmente no que tange ao gerenciamento da infraestutura, estão relacionados à escalabilidade e a extensibilidade.

O aumento vertiginoso do interesse e dos financiamentos em pesquisas na área de Genética e diversas outras áreas afins, fez com que uma atenção especial passasse a ser direcionada para as abordagens desenvolvidas para essas áreas . Esse crescimento constante passou a inserir novos desafios nesta área de pesquisa e, um dos maiores desafios, senão o maior, é a garantia do equilíbrio entre o aumento exponencial da quantidade de dados gerados pelas pesquisas em laboratório e a capacidade de processamento de dados existente para atender a essa demanda. O desenvolvimento de novas estratégias algorítmicas para analisar os dados genômicos passa por evoluções diariamente, com o intuito de se adequar às novas infraestruturas de software e hardware oferecidas.

\subsection{Otimizações de Algoritmos em Bioinformática}

Todo processo de otimização, independente da área na qual é aplicado, tem por objetivo melhorar a eficiência de determinadas tarefas que são realizadas [Coello 1999]. Nem sempre é viável a aplicação de um processo de otimização, visto que, às vezes, os pontos em potencial encontram-se com seus níveis de otimização máximos.

O desenvolvimento de um processo de otimização depende de alguma técnica que possa ser aplicada e que se encaixe de maneira adequada ao problema. Assim, é válido que antes se estude a dimensão do problema a ser otimizado e qual técnica se adequa melhor àquela determinada solução.

Em Bioinformática, a utilização de técnicas de otimização é uma operação bastante recorrente, visto que com o crescimento avassalador da quantidade de informações disponíveis em repositórios de dados, avaliar essa grande massa de informações tornou-se uma tarefa complexa. Em especial, do ponto de vista dos alinhamentos de sequências, a ascensão vertiginosa do número de sequências armazenadas e a necessidade de uma análise 
sobre elas, forçou o desenvolvimento de técnicas de otimização acopladas aos tradicionais algoritmos de alinhamento.

Estratégias como BFO (Bacteria Foraging Optimization)[Passino 2012], busca tabu [Riaz, Wang e Li 2004], simulated annealing [Kim, Pramanik e Chung 1994] e colônias de formigas [Moss e Johnson 2003] são algumas das possíveis heurísticas a serem utilizadas em Bioinformática. Estas se destacam por proverem boas soluções aos problemas de Bioinformática em que são submetidas e são apresentadas com um pouco mais de detalhes nas seções 2.5.1, 2.5.2, 2.5.3 e 2.5.4.

Todas estas estratégias anteriormente citadas são classificadas como heurísticas. Uma heurística é uma abordagem probabilística, que tem por objetivo auxiliar na evolução dos resultados obtidos por diversos métodos [Gallo e Pallottino 1988]. A tomada de decisão sobre qual heurística é a ideal de se utilizar, em um determinado problema, é o ponto chave em relação à garantia da obtenção de bons resultados finais, além de oferecer a possibilidade de ajustes, quando necessários [Dorigo, Caro e Gambardella 1999].

A aplicação de heurísticas para resolver problemas de Bioinformática tem recebido uma atenção especial nos últimos anos. No entanto, alguns problemas em Bioinformática possuem muitas particularidades, tornando a escolha da heurística ideal um desafio [Katoh e Standley 2013]. Dois pontos principais são geralmente considerados, em Bioinformática, para a aplicação de heurísticas: o primeiro deles é a otimização que uma heurística pode oferecer no contexto de busca de caminhos mínimos, e o segundo, é a possibilidade de maximização da pontuação de alinhamentos produzidos, tanto para alinhamentos locais, quanto para alinhamentos globais.

\subsubsection{Bacteria Foraging Optimization - BFO}

A otimização por forrageamento de bactérias (Bacteria Foraging Optimization - BFO) trata-se de um algoritmo de otimização numérico, baseado em população, que toma por guia o comportamento da bactéria Escherichia coli. O comportamento de seleção natural 
das bactérias elimina os organismos com estratégias ruins de forrageamento e privilegia os que obtêm estratégias de sucesso [Passino 2010]. Em geral, aplica-se as técnicas de BFO em problemas que requerem uma solução ótima, usando métodos de localização, captura e ingestão de alimentos, que no aspecto computacional pode ser traduzido para a localização de recursos.

A teoria de forrageamento é baseada na premissa de que a busca dos animais para conseguir alimentos e nutrientes é feita de tal maneira, que o objetivo é maximizar a quantidade de energia $E$ de entrada por unidade de tempo $T$ durante o processo de forragem. Em outras palavras, eles se comportam de modo a encontrar, capturar e consumir alimentos contendo o máximo de calorias, enquanto gastam o mínimo de tempo possível nesta tarefa. Dessa maneira, os organismos tentam maximizar a função $(E / T)$. O entendimento de muitos conceitos ecológicos, como adaptação, fluxo energético e competição, dependem da habilidade de compreender quais alimentos os animais selecionam e o porquê da seleção desses alimentos em específico [Passino 2010].

Para a maioria dos organismos (bactérias, animais, etc) os alimentos e os nutrientes são distribuídos através de caminhos. O forrageamento permite a descoberta de onde se encontram esses caminhos [Passino 2012]. Uma decisão deve ser tomada: entrar em um determinado caminho ou procurar um novo caminho que possa conter alimentos e nutrientes de melhor qualidade, em relação aos caminhos existentes. No caso da execução de forrageamento em grupo, um fator importante para aumentar a probabilidade de se encontrar nutrientes é utilizar a comunicação entre os participantes.

No contexto do uso de otimização em Bioinformática, pode-se citar aplicações como as de análises de sequências de proteínas, que estão dispostas em diversos repositórios de dados e requerem o gerenciamento de múltiplos recursos, para a realização de pesquisas exaustivas nessas bases, como pode ser visto em Vivekanandan e Ramyachitrab [Vivekanandana e Ramyachitrab 2012]. Essas buscas podem ser facilitadas, reduzindose os seus tempos de execução, quando implementadas em um ambiente computacional 
distribuído. Vivekanandan e Ramyachitrab [Vivekanandana e Ramyachitrab 2012] apresentaram um trabalho, em que a estratégia BFO é utilizada para encontrar proteínas similares nas bases de dados. A técnica foi utilizada especificamente para reduzir o tempo que um recurso leva para executar uma requisição do usuário. Ilustrativamente, é como se as bactérias mantivessem registrados os caminhos para os processadores que estão ociosos ou o tempo de realização das tarefas pelos processadores, para então alocar as próximas tarefas para os processadores mais adequados, promovendo um balanço de carga muito eficiente.

Por fim, uma outra aplicação de BFO em Bioinformática, é no auxílio à descoberta de motifs em conjuntos de biossequências, como pode ser visto em Shao e Chen [Shao e Chen 2009]. Os motifs podem ser a indicação de pontos relevantes nas biossequências e, portanto, encontrá-los de forma eficiente é algo desejável.

\subsubsection{Busca Tabu}

O problema de busca tabu trata-se de uma heurística de otimização, que prima pelo uso de características importadas das áreas de otimização linear e técnicas de inteligências artificial. Muito se desenvolveu sobre este método, especialmente para executá-lo em um ambiente computacional.

Diversas aplicações que possuem pontos críticos para tomada de decisão, em que processos complexos de busca por soluções são a única saída, enquadram-se como abordagens ideais para a heurística de busca tabu [Glover e Laguna 1997].

Existem diversos trabalhos em Bioinformática que se utilizam de busca tabu para otimizar as suas operações. Dentre as abordagens mais clássicas dessa heurística em Bioinformática, encontra-se a sua utilização para otimizar problemas de alinhamento global de sequênicas, quando existem restrições a serem obedecidas [Riaz, Wang e Li 2004]. Além disso, a busca tabu pode ser utilizada no pós-processamento das sequências alinhadas, refinando os processo de descoberta de padrões em biossequências [Riaz, Yi e Li 2005]. 


\subsubsection{Simulated Annealing}

Dentre diversas heurísticas existentes, o Simulated Annealing pode ser classificado como um dos métodos mais custosos computacionalmente. No entanto, apesar de ser um método custoso computacionalmente por se basear no Método de Monte Carlo, a sua utilização é quase sempre vista de maneira positiva, pois o custo computacional é compensado pela qualidade dos resultados produzidos por esta heurística [Kalos 2007, Kirkpatrick, Gelatt e Vecchi 1983].

A ideia que norteia a heurística de Simulated Annealing, é que a partir de conjunto de estados $X=\left\{x_{1}, \ldots, x_{n}\right\}$ e uma função custo $C: X \rightarrow R$, procura-se um estado ótimo $x_{\text {opt }}$. As diversas iterações para encontrar um estado ótimo baseiam-se nas seguintes regras, as quais levam em consideração o fator de decaimento da temperatura $T$ que controla a probabilidade de aceitar um novo estado $x_{\text {new }}$ :

1. Se $\Delta \mathrm{E} \leq 0$, aceita um novo estado $x_{\text {new }}$ com $\Delta \mathrm{E}$ sendo a variação de energia.

2. Se $\Delta E>0$, aceita um novo estado $x_{\text {new }}$ com probabilidade $P(\Delta E)=e^{-\Delta E / T}$, onde $T$ é a temperatura e $\Delta \mathrm{E}=\mathrm{C}\left(\mathrm{x}_{\text {new }}\right)-\mathrm{C}\left(\mathrm{x}_{\text {current }}\right)$ é a diferença de custo.

Apesar do grande custo computacional, em alguns casos, para a execução das aplicações em Bioinformática que utilizam soluções baseadas em Simulated Annealing, esse método, quando bem modelado e aplicado, apresenta soluções com excelente relevância em termos biológicos. A implementação dessas soluções em ambientes computacionais de alto desempenho, com grande capacidade de processamento, torna o uso dessa estratégia bastante viável, excluindo-se a preocupação com os problemas de vazão descritos anteriormente [Mareuil et al. 2011, Zhu et al. 2011].

Por fim, pode-se aplicar o Simulated Annealing para auxiliar na realização de alinhamentos de sequência. Correa et al. [Correa et al. 2012] propuseram uma abordagem que utiliza pesos para classificar quais os melhores resíduos a serem alinhados, através de uma rede neural. No entanto, para auferir um bom conjunto de pesos a serem utilizados, o 
Simulated Annealing é uma boa estratégia. Para melhorar o seu desempenho, a estratégia de Simulated Annealing, para este caso, foi paralelizada.

\subsubsection{Colônia de Formigas}

A última heurística a ser elencada no presente trabalho é a de colônia de formigas (Ant Colony). Dentro das suas atribuições possíveis, a heurística de colônia de formigas é bastante eficiente nos processos de busca de caminho mínimo [Dorigo e Blum 2005, Dorigo e Gambardella 1997].

A implementação da heurística de colônia de formigas destaca-se pela sua baixa complexidade computacional, tornando muito eficientes os processos que a utilizam. Além disso, a sua modelagem matemática, faz com que os seus resultados também sejam bastante precisos, a exemplo do simulated annealing [Papadimitriou e Steiglitz 1982].

Como esta heurística se baseia no comportamento real de formigas, é classificada como uma heurística bioinspirada [Ho et al. 2005]. A sua operação fundamenta-se no movimento realizado pelas formigas na busca de alimentos. A busca aleatória inicialmente realizada pelas formigas e a consequente demarcação das trilhas com feromônio, faz com que todas as formigas da colônia, com o passar do tempo, direcionem-se para o caminho mais curto [Moss e Johnson 2003].

Do ponto de vista de modelagem e posterior implementação computacional, deve-se levar em consideração que, primeiramente as soluções candidatas utilizam-se de um modelo de distribuição de probabilidades parametrizado, em que as probabilidades são os reforços de feromônio e, em segundo lugar, deve-se utilizar as soluções obtidas para atualizar os valores probabilísticos (feromônio), em um processo de retroalimentação de soluções, cuja solução atual é considerada como entrada para a próxima solução [Blum e Roli 2003].

As aplicações de colônia de formigas em Bioinformática podem ser variadas, partindo da utilização desta heurística para otimizar processos de alinhamento múltiplo de sequências, com a aceleração da busca por motifs e até, eventualmente, atuar de ma- 
neira concomitante com algoritmos de programação dinâmica em determinadas estratégias [Moss e Johnson 2003].

Finalmente, é possível ainda aplicar a técnica de colônia de formigas, para auxiliar na predição de estruturas tridimensionais de proteínas. A técnica de otimização pode dar suporte na geração do modelo de backbone, que é a fase inicial para predição de estruturas de proteínas, através da construção paralela de matrizes de feromônio [Qiang et al. 2013]. 


\section{Ferramentas de Alinhamento Múltiplo de Sequências}

Neste capítulo são apresentadas algumas ferramentas bem conhecidas e amplamente utilizadas para a realização de alinhamento múltiplo de sequências. Cada uma das ferramentas possui suas características particulares, cujas funcionalidades as tornam úteis.

\subsection{Aplicações de Computação de Alto Desempenho em Bioinformática}

Existe uma extensa gama de aplicações de Bioinformática que podem ser tratadas e, consequentemente, alcançarem um melhor desempenho em termos de execução, armazenamento e comunicação, quando executadas em ambientes computacionais de alto desempenho. Essas aplicações tendem a apresentar uma evolução muito significativa em diversos quesitos inerentes aos problemas tratados por elas, principalmente devido à alta disponibilidade, confiabilidade e eficiência dos recursos computacionais [Bader. et al. 2005, Milne et al. 2009].

Psomopoulos e Mitkas [Psomopoulos e Mitkas 2010] apresentam uma abordagem teórica, com uma metodologia unificada para o direcionamento de todo o rol de recursos de um sistema computacional distribuído para a solução de problemas bastante específicos em Bioinformática. Esses problemas, em geral, possuem muitas restrições para a sua execução, com uma vasta dependência de dados. Além disso, mostra-se um protótipo de uma ferramenta que implementa esses processos de especificação e auxilia pesquisadores 
na avaliação das necessidades computacionais de uma determinada tarefa e na otimização da alocação dos recursos disponíveis.

Uma outra vertente abordada é o uso das grades computacionais para análise de sequências, especificamente na busca por similaridades. Carvalho et al. [Carvalho et al. 2005] propuseram o desenvolvimento de uma plataforma denominada Squid, que faz uso de grades computacionais para a execução de operações utilizando o algoritmo BLAST, para pesquisas em bases de dados genômicas. No entanto, a ferramenta é capaz de se adaptar a outras aplicações de Bioinformática relacionadas à computação intensiva e repetitiva de dados, com bastante flexibilidade.

Existem ainda outras abordagens que também desenvolveram uma plataforma genérica para execução de aplicações de Bioinformática em grades computacionais. Por exemplo, pode-se citar a abordagem apresentada por Andrade et al. [Andrade et al. 2006], corroborando a ideia de multi-plataforma e comparando sua execução com as realizadas em ambientes de clusters dedicados e máquinas sequenciais, como pode ser visto também em Parke et al. [Parke et al. 2013]. Além disso, vislumbrando-se que os potenciais usuários dessas ferramentas computacionais não tenham conhecimentos avançados em computação, existem propostas que auxiliam a submissão dos dados e em seu tratamento, como o proposto por Rius et al. [Rius et al. 2011].

Do ponto de visto da dimensão dos problemas de Bioinformática a serem executados em ambientes computacionais de alto desempenho, pode-se concluir da abordagem proposta por Stockinger et al. [Stockinger et al. 2006] que, para se obter o melhor desempenho desses ambientes e utilizar eficientemente os seus recursos, quanto maior a magnitude do conjunto de sequências a serem analisada, melhores serão os resultados de tempo de execução e, consequentemente, de speedup. Com uma abordagem baseada em Cadeias de Markov Ocultas (HMM), Stockinger et al. [Stockinger et al. 2006] criaram um serviço que particiona automaticamente os conjuntos de dados de entrada e cria um mapa de como distribuir paralelamente a carga de trabalho. 
As análises em Biologia Molecular demandam grande poder computacional para completar os seus resultados, principalmente na predição de estruturas moleculares, que, em geral, são bastante complexas. Com isso, os sistemas computacionais de alto desempenho assumem um papel importante para realizar o tratamento dessas informações, como proposto por Sadasivam e Baktavatchalam [Sadasivam e Baktavatchalam 2010]. Nesta mesma vertente, Mareuil et al. [Mareuil et al. 2011] fazem uso de computação de alto desempenho para realizar os cálculos necessários nos estudos conformacionais de proteínas, sob os dados obtidos através de ressonância magnética nuclear.

Finalmente, os alinhamentos múltiplos de sequências e as técnicas de reconhecimento de padrões são, também, duas vertentes em Bioinformática que necessitam de grande poder computacional. Ambas as vertentes são estratégias algorítmicas que, em muitos casos, para serem implementadas de maneira a obterem bons resultados finais, agregam grande complexidade computacional [Montañola et al. 2013]. Assim, a utilização de sistemas computacionais de alto desempenho para realizar essas tarefas é um recurso que pode tornar essa execução viável [Borovska, Gancheva e Ko 2013, Church et al. 2011].

Nas seções 3.2, 3.3, 3.4 , 3.5, 3.6 e 3.8, a seguir, são apresentadas algumas ferramentas para alinhamento de sequências em Bioinformática, além de uma análise comparativa entre elas, com relação à ferramenta proposta no presente trabalho.

\subsection{Clustal Omega}

Dentre as várias ferramentas pertencentes à família Clustal de soluções, a Clustal Omega é a mais recente delas [Sievers e Higgins 2014]. Esta ferramenta opera tanto com conjuntos de sequências de aminoácidos, quanto de nucleotídeos, o que a torna uma ferramenta de abordagem genérica para a realização de alinhamento múltiplo de sequências. A Clustal Omega utiliza a classe de algoritmos progressivos, devido aos bons resultados que este tipo de algoritmo oferece.

Uma evolução apresentada por esta ferramenta é a sua capacidade de trabalhar 
com conjuntos de sequências muito maiores do que as outras ferramentas de cunho sequencial, ou seja, que não executam em ambiente de computação de alto desempenho [Sievers et al. 2011]. Além disso, mesmo com a operação com grandes conjuntos de sequências, esta ferramenta tenta prezar pela qualidade de seus alinhamentos finais.

O destaque desta ferramenta, do ponto de vista de eficiência computacional, é a utilização do algoritmo $m B E D$ para calcular a sua árvore guia, ou filogenética. Este algoritmo é muito eficiente e a sua otimização é desenvolvida para a execução em computadores sequenciais [Sievers e Higgins 2014].

Do ponto de vista de alinhamentos finais, a utilização do método HHalign, baseado nos modelos de markov ocultos (HMM) para a fase do alinhamento múltiplo, é o fator que a diferencia em termos de melhora de qualidade.

Um elemento importante a ser ressaltado da Clustal Omega é que ela permite que os usuários reutilizem alinhamentos produzidos, para evitar recálculos. Além disso, esta ferramenta permite que o usuário especifique o perfil do HMM, que é derivado de um alinhamento de sequências que são homólogas ao conjunto de entrada [Sievers et al. 2011].

\subsection{Dialign}

O Dialign [Morgenstern et al. 1998] trata-se de uma ferramenta que realiza tanto alinhamento par-a-par, ou seja exato, quanto alinhamento múltiplo, ou seja estocástico. O Dialign difere-se de outras ferramentas de alinhamento de sequência, pois não realiza comparação entre resíduos isolados e tampouco utiliza-se de penalidades com espaços (gaps). Esta ferramenta constrói alinhamentos através da comparação entre segmentos inteiros de sequências, o que privilegia a busca por similaridades locais e não globais [Morgenstern et al. 1998].

Na ferramenta Dialign, é possível realizar tanto o alinhamento de sequências de nucleotídeos, quanto de aminoácidos. No entanto, como o Dialign é uma ferramenta que 
privilegia os resultados de alinhamentos locais, a sua aplicação oferece bons resultados na análise de motifs que são conservados em famílias de proteínas.

O nome da ferramenta advém da forma como o seu algoritmo executa, através do alinhamento diagonal das sequências conforme pode ser visto na figura 10 [Morgenstern et al. 1998].

Figura 10: Exemplo de cálculo diagonal do Dialign.

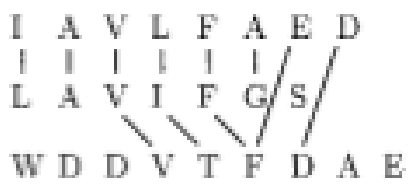

Fonte: Morgenstern et al. (1998)

Os pares de segmentos formam diagonais que são comparadas para formar uma matriz de pontos. As diagonais formadas podem ser de tamanhos diversos e o que se almeja é um conjunto de diagonais com algum critério de consistência. Esta consistência é necessária para que não ocorram duplicações de elementos a serem pontuados e atribuições de crossover entre os resíduos, o que pode ocasionar uma degradação do resultado final. Através de uma função probabilística de pesos, atribuem-se pesos a cada diagonal possível de ser formada e tenta-se estabelecer uma coleção consistente de diagonais, maximizando-se a soma dos pesos.

Sabe-se que, embora o Dialign produza resultados finais com boa significância biológica, esta ferramenta não apresenta um bom desempenho em termos de tempo de execução. Assim, de forma a melhorar um pouco o seu desempenho, houve a proposta de uma versão paralela do Dialign, em que as sequências alinhadas pela estratégia para-par são distribuídas entre as unidades de processamento [Schmollinger et al. 2004]. No entanto, é uma abordagem que não ganhou amplo destaque. 


\subsection{Saga}

$\mathrm{Na}$ vertente das ferramentas estocásticas com algoritmos evolutivos, encontra-se a Saga [Notredame e Higgins 1996]. Nesta ferramenta, implementou-se uma abordagem para a realização de alinhamento múltiplo de sequências utilizando-se algoritmos genéticos como base.

O método contempla a evolução de uma população de alinhamentos, tomando como referência durante a sua execução regras evolucionárias e, gradualmente, a cada nova iteração, mensura-se a qualidade dos alinhamentos produzidos através de uma função objetivo.

Um mecanismo interessante da ferramenta Saga é o controle automático estabelecido para escalonar a utilização dos seus 22 operadores de alinhamento. Este controle condiciona a aplicação de recombinação e mutação entre as gerações de soluções [Notredame e Higgins 1996].

A utilização, pelo Saga, da função objetivo de soma de pares ponderados (Weighted Sum of Pairs - WSP), destaca-se por produzir resultados com boa qualidade e precisão, especialmente quando comparados com alinhamentos de referência de estruturas terciárias de proteínas. No entanto, devido à utilização de um método altamente iterativo, esta ferramenta também esbarra no problema relacionado à questão do seu desempenho em termos de tempo de execução. Isto, em muitos casos, torna inviável a sua execução para grandes conjuntos de sequências.

\subsection{MAFFT}

Com uma proposta inovadora, a ferramenta MAFFT [Katoh e Standley 2013] destacou-se no seu surgimento, promovendo o alinhamento múltiplo de sequências através do uso da trasformada rápida de Fourier (FFT). Trata-se de uma abordagem praticamente única, porém bem sucedida, do uso de transformada de Fourier para resolver alinhamento 
múltiplo de sequências.

Enalteceu-se a MAFFT devido à redução de tempo de processamento alcançada, quando comparado com outras abordagens sequenciais para alinhamentos múltiplos. Mesmo com a redução no tempo de processamento, é possível obter, com a MAFFT, bons resultados em termos de significância biológica dos alinhamentos finais.

A ideia da MAFFT é dividida, basicamente, em duas partes: a primeira está relacionada à identificação rápida de regiões homólogas através da FFT e, a segunda, contempla o desenvolvimento de um método mais eficiente para calcular pontuações dos alinhamentos. Com esta segunda parte, reduz-se o tempo global de processamento e melhora-se a confiabilidade do alinhamento, com conjuntos de sequências de mesmo tamanho. No entanto, a MAFFT não atua com muita eficiência para conjuntos de sequências pouco relacionadas e com muitos trechos de inserções [Katoh e Standley 2013].

Em relação à estratégia algorítmica utilizada, duas heurísticas diferentes foram implementadas sobre a FFT. A primeira estratégia baseia-se em uma abordagem progressiva para normalizar uma matriz de pontuação e reduzir o tempo de processamento em seu cálculo. A segunda, trata-se de um método iterativo para refinar a pontuação final do alinhamento, através da subdivisão em grupos, das sequências alinhadas.

A MAFFT, assim como outras ferramentas, necessitou de evoluções para se adequar a operação com conjuntos de sequências cada vez maiores, tanto de nucleotídeos, quanto de proteínas. Para melhorar o seu desempenho, implementou-se uma estratégia com threads, para execução em computadores pessoais com processadores de múltiplos núcleos [Katoh e Toh 2010]. No entanto, da mesma forma que a maioria das ferramentas de alinhamento de sequências, o uso dessa estratégia acaba por não explorar a capacidade de processamento de sistemas computacionais de alto desempenho. 


\subsection{ClustalW-MPI}

O ClustalW-MPI [Li 2003], implementado para a execução em sistemas computacionais paralelos e distribuídos, é uma variante do amplamente conhecido e consagrado ClustalW. Este trata-se de uma ferramenta muito bem sucedida para alinhamento múltiplo de sequências e que utiliza um algoritmo progressivo como base.

Na implementação do ClustalW-MPI, procurou-se paralelizar a primeira fase do alinhamento, cuja granularidade grossa permite tal estratégia, através de uma alocação independente de tarefas nos processadores. Utilizou-se de uma abordagem denominada rajada de tamanho fixo (fixed-size chunking - FSC), cuja ideia é enviar lotes de tarefas de tamanho fixo para serem alocadas nos processadores. Com isso, também foi possível minimizar os custos de comunicação na rede [Li 2003].

Uma outra melhoria desenvolvida nesta ferramenta relaciona-se à última fase do alinhamento progressivo. Dependendo da topologia da árvore filogenética (guia), é possível realizar alguns alinhamentos dos perfis em paralelo. No entanto, isso pode degradar a qualidade dos alinhamentos finais se não for bem gerenciado [Li 2003].

É importante salientar que, diferentemente da maioria das outras ferramentas, a ClustalW-MPI pode ser executada em um sistema computacional de alto desempenho, como um cluster ou uma grade.

\subsection{Alinhamento múltiplo paralelo e otimização atra- vés de colônia de formigas}

Uma outra abordagem interessante, desenvolvida para alinhamento múltiplo de sequências, foi proposta por Zafalon [Zafalon 2009]. Nesta abordagem, realiza-se a paralelização do algoritmo de alinhamento múltiplo progressivo, na fase de construção da matriz de pontuação, que é a primeira fase do algoritmo, e a utilização de uma heurística bioinspirada, que é a de colônia de formigas, para a realização da fase de alinhamento 
múltiplo, que é a terceira fase do algoritmo. Esta implementação foi desenvolvida para a execução em clusters.

No processo de paralelização da primeira fase, distribui-se os pares de sequências entre os nós componentes do cluster e um algoritmo de estimativa de pontuação é executado para o cálculo dessas pontuações. Com isso, reduziu-se o tempo de processamento desta fase, contribuindo-se para o decréscimo global do tempo de processamento da ferramenta, visto que a primeira fase é a mais crítica da abordagem progressiva.

Além disso, implementou-se a heurística de otimização bioinspirada de colônia de formigas para a realização da fase de alinhamento múltiplo. Nesta fase, almejou-se a adequação na forma de pontuar da função objetivo, permitindo que a qualidade dos resultados finais do alinhamentos fosse melhorada.

Com as duas proposições implementadas nesta abordagem, permitiu-se que a ferramenta apresentasse tanto ganhos de desempenho, quanto de qualidade.

\subsection{Análise Comparativa}

Para finalizar este capítulo, em que são apresentadas algumas das mais utilizadas ferramentas de alinhamento múltiplo de sequências, é relevante realizar uma análise comparativa entre as ferramentas aqui apresentadas e a ferramenta proposta no presente trabalho.

Pode-se perceber que todas as ferramentas apresentam pontos de qualidade e pontos de desqualificação. No entanto, também nota-se que praticamente todas as ferramentas não abstraem para uma abordagem híbrida, com múltiplas estratégias, como é o caso da ferramenta proposta no presente projeto. Percebe-se ainda que existem tentativas de se aplicar variações de estratégias implementadas dentro da ferramenta, como é o caso das ferramentas da família Clustal ou da MAFFT, porém não a inserção de novas estratégias.

Além disso, um ponto importante a ser ressaltado, relaciona-se ao desenvolvimento 
de abordagens que consigam trabalhar com grandes conjuntos de sequências, visto que esses conjuntos são uma tendência nas grandes bases de dados genômicas. As ferramentas, em geral, possuem limitação de desempenho para operar com esses conjuntos, exceto se sua abordagem possa ser executada em ambientes computacionais de alto desempenho, como é o caso da ClustalW-MPI, da abordagem proposta por Zafalon [Zafalon 2009] e da abordagem proposta no presente trabalho. Vale ressaltar, que a abordagem proposta por Zafalon [Zafalon 2009] não oferece um mecanismo de particionamento paralelo, o que a torna menos eficiente que a abordagem proposta no presente trabalho, para a operação com grandes conjuntos de sequências.

O direcionamento do tipo de alinhamento a ser produzido, se local ou global, também é outro ponto que deixa as ferramentas razoavelmente incompletas. Em geral, projeta-se a ferramenta para atender uma demanda específica, visto que a generalização é uma tarefa um pouco mais árdua. A proposta da ferramenta do presente trabalho diferencia-se por oferecer uma abordagem tanto para alinhamentos globais, quanto para locais.

Finalmente, sob a ótica da qualidade dos alinhamentos finais produzidos, especialmente com relação à significância biológica, as ferramentas muitas vezes restringem o seu escopo de operação para uma abordagem não genérica, de modo a evitar a necessidade de ajustes ou por não terem encontrado a heurística correta para tratar essa questão. A ferramenta proposta no presente trabalho adequa-se a esta necessidade, com uma aplicação de um método iterativo paralelo, cuja entrada advém do resultado da execução de um método otimizado de busca de caminho, sem a necessidade de outras informações adicionais. 


\section{Alinhamento Múltiplo de Sequências Aplicando Estratégias Híbridas $e$ Paralelismo}

Neste capítulo, apresenta-se a otimização de algoritmos de alinhamento múltiplo de sequências, utilizando-se estratégias híbridas, para sistemas paralelos e distribuídos.

\subsection{Considerações Iniciais}

As seções a seguir apresentam as descrições dos algoritmos de alinhamento múltiplo paralelos concebidos para a execução em ambientes computacionais de alto desempenho. Com a implementação da proposta, aqui apresentada, reduziu-se ainda mais o tempo de processamento dos conjuntos de biossequências e pode-se trabalhar com um número cada vez maior delas, possibilitando análises mais complexas, com mais organismos. Trabalhar com conjuntos cada vez maiores de sequências alinha-se à tendência mundial de pesquisa na área de estudos genômicos, em que o número de organismos com os seus genomas sequenciados e a quantidade de dados gerada tornam inviáveis as realizações de quaisquer análises sem o tratamento de grandes massas de dados. É importante ressaltar, que os conjuntos de sequências não sofrem acréscimos apenas nas quantidades de sequências, mas também no comprimento de cada uma das sequências. 


\subsection{Descrição da Proposta}

A ideia principal da proposta desenvolvida no presente trabalho relaciona-se à produção de uma ferramenta de alinhamento múltiplo de sequências. No entanto, com a complexidade para a realização das tarefas de alinhamento múltiplo de sequências, algumas estratégias foram acopladas à ferramenta, de modo a otimizar tanto o seu tempo de execução, quanto a qualidade de seus alinhamentos finais produzidos. O algoritmo utilizado como base para a ferramenta é o algoritmo múltiplo progressivo, cujas três fases, construção da matriz de pontuação, construção da árvore filogenética e alinhamento múltiplo propriamente dito, passaram por processos de otimização.

A primeira estratégia é a paralelização da construção da matriz de pontuação, primeira fase do algoritmo progressivo. Nesta fase, paraleliza-se a execução dos alinhamentos par-apar, além de promover o particionamento desses pares de sequências paralelizados, quando os seus respectivos comprimentos forem maiores do que o tamanho médio das sequências componentes de um conjunto.

Como uma segunda estratégia, aplica-se um algoritmo de otimização baseado na heurística bioinspirada de colônia de formigas, para a segunda fase do algoritmo progressivo, que é a geração da árvore filogenética. A forma como o algoritmo de colônia de formigas foi projetado para a realização de buscas de caminho mínimo o torna mais eficiente do que outros algoritmos utilizados para esta fase. Foram realizados testes que mostram esta eficiência e estão apresentados na seção 5

Finalmente, a terceira estratégia baseia-se na heurística iterativa paralelizada de simulated annealing, para refinar os resultados obtidos na terceira fase do algoritmo progessivo. Nesta fase, realiza-se o alinhamento múltiplo propriamente dito, em que as sequências são reajustadas para a produção do alinhamento final. 


\subsection{Construção da Matriz de Pontuação}

Dentro da construção de algoritmos de alinhamentos múltiplos de sequência, especialmente na classe dos algoritmos progressivos, o desenvolvimento de técnicas de particionamento para a realização de algumas de suas fases, quando possível, é de grande interesse, especialmente quando se relaciona à possibilidade de redução de tempo de processamento.

No desenvolvimento do presente trabalho, fez-se uso de um algoritmo de alinhamento múltiplo progressivo, que, dentro da classe alinhamentos múltiplos, apresentase como um dos mais eficientes e amplamente utilizado [Angiuoli e Salzberg 1994, Edgar e Batzoglou 2006, Thompson, Higgins e Gibson 1994]. Dessa forma, primeiramente, realizou-se a paralelização dos alinhamentos par-a-par, em que os pares de sequência podem ser distribuídos entre as unidades de processamento. No entanto, quando esses pares de sequências possuem um grande comprimento, opta-se por promover um particionamento da operação da primeira fase desse algoritmo, em que os pares são subdivididos em trechos menores, para que se possa reduzir a sua complexidade e, consequentemente, o tempo de processamento para os alinhamentos par-a-par. Assim, possibilitou-se explorar toda a capacidade de processamento dos ambientes computacionais de alto desempenho e, dessa forma, trabalhar com conjuntos cada vez maiores de sequências. Vale ressaltar que a entrada dos pares de sequência acontece de forma serial, para, posteriormente, realizar-se a paralelização.

Nesses sistemas computacionais de alto desempenho, é possível explorar a capacidade de vários nós que o constituem, sejam esses nós contendo um único processador, com vários núcleos ou não, ou clusters, os quais podem ser compostos por diversos servidores e esses servidores podem oferecer, ou não, vários núcleos.

\subsubsection{Método de Particionamento}

Em princípio, realiza-se a distribuição dos pares de sequência entre os nós de processamento. Dessa maneira, consegue-se utilizar todos os nós disponíveis para processamento 
no ambiente de alto desempenho que for executado, desde que haja um ambiente de passagem de mensagem, como parte fundamental. Esta verificação é apresentada na figura 11 através de um diagrama de fluxos e descrita de maneira algorítmica como pode ser verificado no Algoritmo 1.

Figura 11: Fluxograma do algoritmo para distribuir pares de sequências às unidades de processamento.
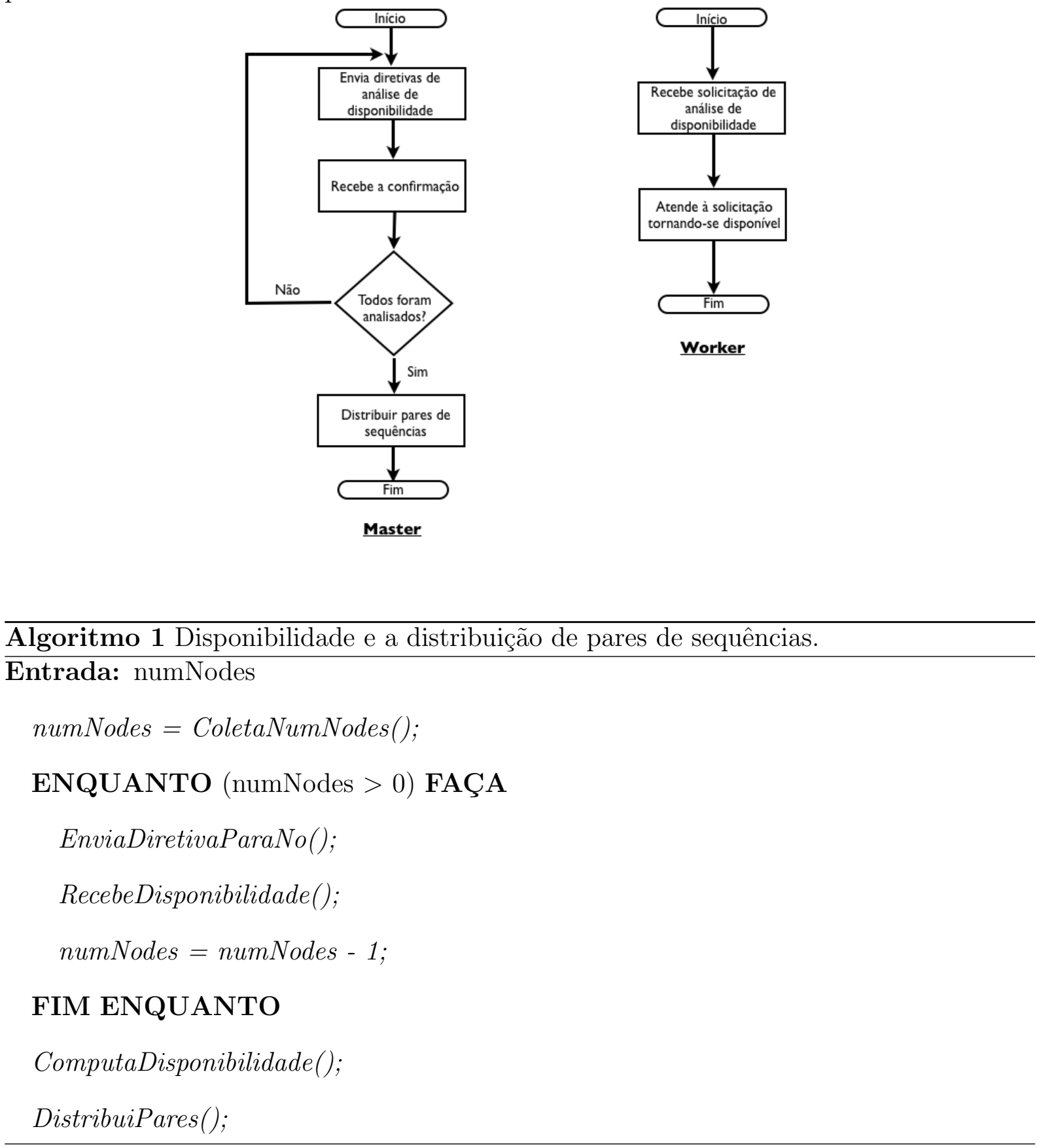

Muitas vezes, o tamanho (comprimento) das sequências existentes, a serem alinhadas 
pelo algoritmo de alinhamento global par-a-par, é muito grande. Por exemplo, no contexto de pirossequenciamento [Huse et al. 2007], os resultados obtidos geram milhões de sequências, e estas sequências obtidas são, em vários casos, cadeias na ordem de milhares de pares de base. Dessa forma, durante a execução do alinhamento par-a-par, o par de sequências do alinhamento pode ser particionado em pedaços menores, realizando operações de subalinhamentos par-a-par sobre esses pedaços e, posteriormente, concatenando o resultado final, para compor a pontuação do alinhamento global. Com isso, possibilita-se a redução do tempo de processamento para esta operação e explora-se, com maior eficiência, a quantidade de recursos disponíveis no sistemas computacionais de alto desempenho. Na figura 12, apresenta-se um diagrama de fluxo para o algoritmo de gerenciamento do particionamento desenvolvido e, em seguida, a sua descrição algorítmica (Algoritmo 2).

Figura 12: Fluxograma do algoritmo de construção da matriz de pontuação.

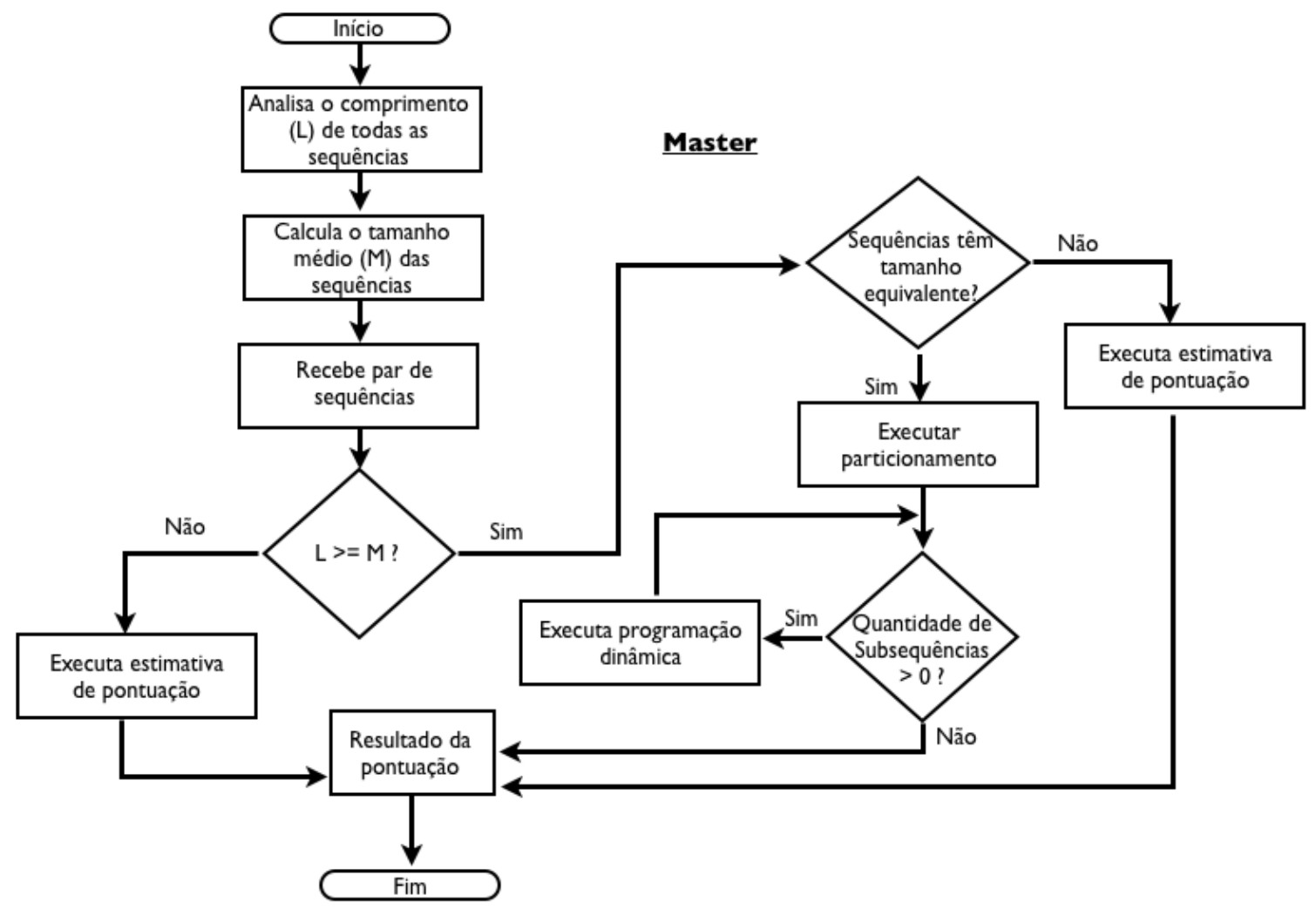

Através do esquema de gerenciamento apresentado no fluxograma da figura 12 e descrito no algoritmo 2 realizam-se verificações quanto ao tamanho das sequências e as suas características, com a ideia de selecionar se o par de sequências a ser tratado é suficien- 


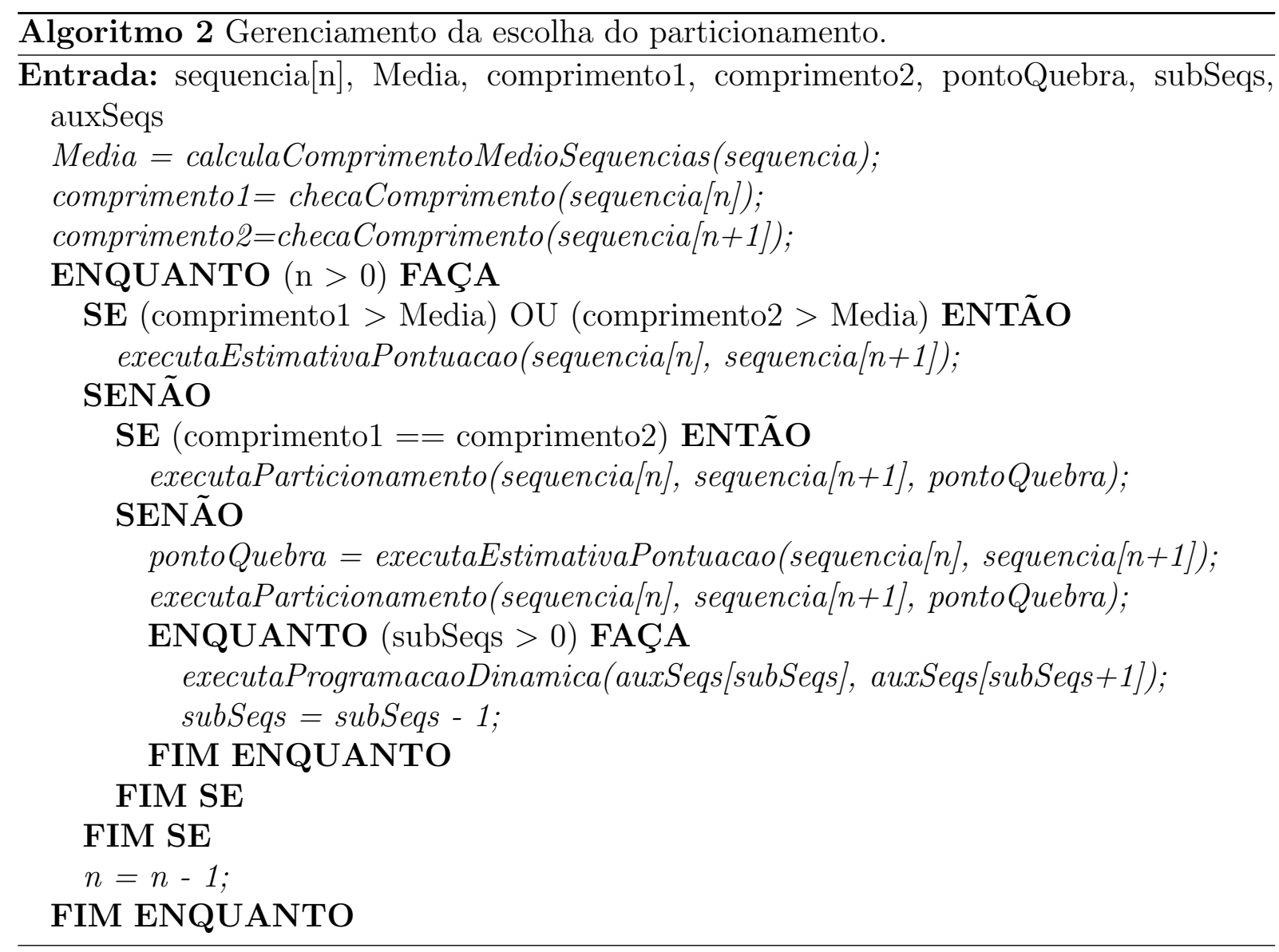

temente grande para se utilizar a técnica de particionamento proposta, ou se fará uso do algoritmo de estimativa de pontuações, o qual é apresentado na seção 4.3.2. A tomada de decisão para se utilizar o particionamento, ou não, está relacionada a saber se o comprimento das sequências, que compõem o par, é maior ou igual ao tamanho médio das sequências da amostra a ser analisada. Caso haja a necessidade de particionamento, o algoritmo de gerenciamento deve validar, tomando como base a relação de equivalência entre os comprimentos das sequências, os chamados pontos de quebra. Serão consideradas sequências de comprimentos equivalentes as que possuem o mesmo comprimento, o que pode ser bem definido nos sequenciadores automáticos, através de delimitações nos tamanhos das sequências. Portanto, escolhidos os possíveis pontos de particionamento, os trechos do par de sequência são direcionados, para as unidades de processamento, para serem alinhados.

Com relação à quantidade dos pontos de quebra, este fator está ligado à quanti- 
dade de unidades de processamento disponíveis. No entanto, devido às diferentes configurações de arquiteturas dos sistemas computacionais de alto desempenho, se esta quantidade for demasiadamente grande, o processo de quebra torna-se muito fracionado [Jackson et al. 2010, Schmidt 2011]. O fracionamento extremo, em geral, é um fator que contribui para melhora no desempenho, porém, nem sempre para a qualidade do alinhamento final. Dessa forma, a partir de estudos conduzidos e de levantamentos na literatura, percebeu-se que uma boa medida é um número de partes, que serão distribuídas às unidades de processamento, menor ou igual a $1 \%$ do comprimento do par de sequências a ser analisado [Liu e Schmidt 2014, Plyusnin e Holm 2005, Roshan 2014, Yang et al. 2011].

De modo a ilustrar a ideia, considere, como exemplo, um par de sequências com 100 pares de base (bp), demonstrado de forma compacta, conforme disposto a seguir:

\section{$\mathrm{S} 1=$ ACTTACCGAAGTCACAGT(...)CCATAACAGGTCAGCGTCGTAAAC \\ S2 = AGTTGTCCCTATCGATAA(...)GTGATGTGCCGATAACTAGATGATCG}

Considerando P a quantidade de partições e L o comprimento da sequência, tem-se:

$$
\begin{gathered}
P=L * 0.01 \\
P=100 * 0.01 \\
P=1
\end{gathered}
$$

Portanto, com $\mathrm{P}=1$ tem-se uma partição, ou seja, o par de sequências é dividido em duas partes iguais (duas divisões). Assim, considerando D o número de divisões, tem que:

$$
\mathrm{D}=\mathrm{P}+1
$$

No caso do exemplo anterior, D é igual a 2. 
Nos casos em que $\mathrm{P}<1$, adota-se que não haverá particionamento e o par de sequências é alocado por inteiro na unidade de processamento. O algoritmo 3 descreve o funcionamento do mecanismo de particionamento e distribuição. Sabendo-se que NP é o número de unidades de processamento, em quaisquer condições, seja para $\mathrm{P} \geq \mathrm{NP}$ ou $\mathrm{P} \leq \mathrm{NP}$, o algoritmo 3 procede a alocação ordenada, sempre no intuito de maximizar a distribuição das partições.

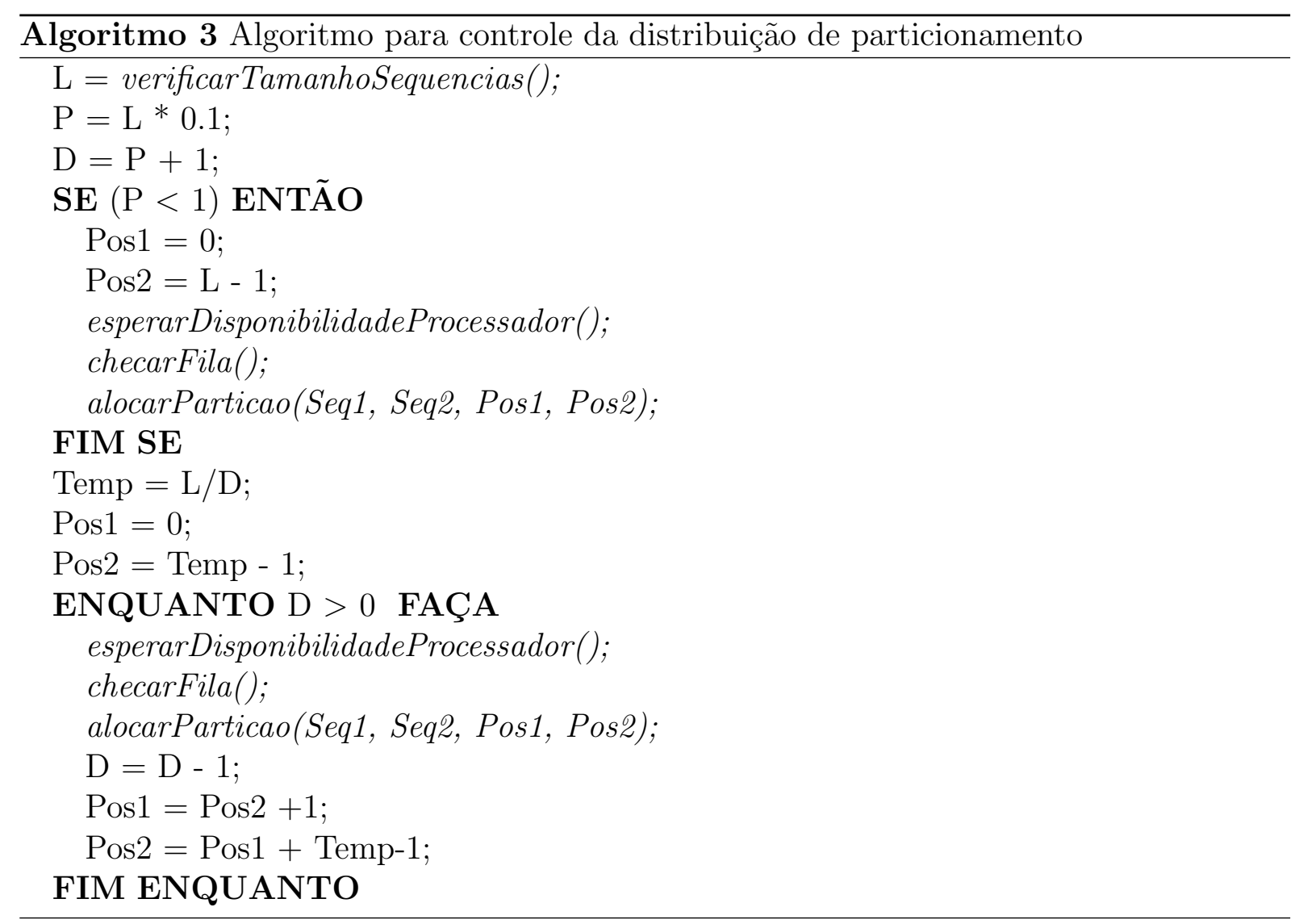

A recomposição da pontuação obtida nos subalinhamentos realizados durante o particionamento, para utilização na matriz de pontuação, é feita com a junção das pontuações, através de um cálculo do valor médio das pontuações obtidas nos subalinhamentos. É importante salientar que o particionamento deve ser considerado quando se adota o contexto de sequências de tamanho equivalente, conforme citado anteriormente, garantindo que esse procedimento tenha significado biológico no final. O grau de equivalência, ou seja, as sequências possuírem o mesmo tamanho, é o ponto chave para o sucesso dessa abordagem. A manutenção do sentido biológico ocorre pois, devido ao longo comprimento 
das sequências, mesmo com as quebras realizadas em diversos pontos das sequências, as pequenas diferenças produzidas nas regiões, com a readequação de alguns resíduos (nucleotídeos ou aminoácidos) nos diferentes blocos particionados, não ocasionam alterações relevantes nos resultados. Assim, a soma da pontuação final é computada da seguinte forma:

$$
S_{i j}=\left(\sum_{t=0}^{t=p} s_{t}\right) /(p+1),
$$

considerando $S_{i j}$ a pontuação (Score) final a ser inserida na matriz de pontuação e $s_{t}$ a pontuação parcial a ser computada em cada partição para ser utilizada na composição da média das pontuações.

Com o algoritmo de gerenciamento do particionamento apresentado anteriormente, faz-se necessário demonstrar o funcionamento do mecanismo de particionamento propriamente dito. Mostra-se, na figura 13, a ilustração do funcionamento desse mecanismo.

Considerou-se, na figura 13, a representação do particionamento em um pequeno trecho de um par de sequências. Conforme discutido anteriormente, levando-se em conta que haja a necessidade de particionamento, ele poderá ocorrer com sequências de tamanhos equivalentes. Se as sequências forem de tamanho equivalente, haverá a necessidade de uma escolha dinâmica, para saber em quantos trechos elas serão particionadas, procurando ocupar o máximo de unidades de processamento disponíveis, almejando o ganho máximo de desempenho na estratégia de alinhamento.

Como pode ser visto na figura 13, escolheu-se realizar o particionamento do par de sequências de tal forma que cada trecho conta com 10 nucleotídeos, ou seja, cada bloco de 10 nucleotídeos direcionados para serem processados por algum núcleo (ou unidade). Para facilitar a ilustração, apresentou-se apenas um trecho dos pares de sequência e omitiu-se a quantidade de trechos particionados.

Essa divisão dos subalinhamentos, de maneira especial nos nós de sistemas compu- 
Figura 13: Ilustração do mecanismo de particionamento das sequências a serem alinhadas.

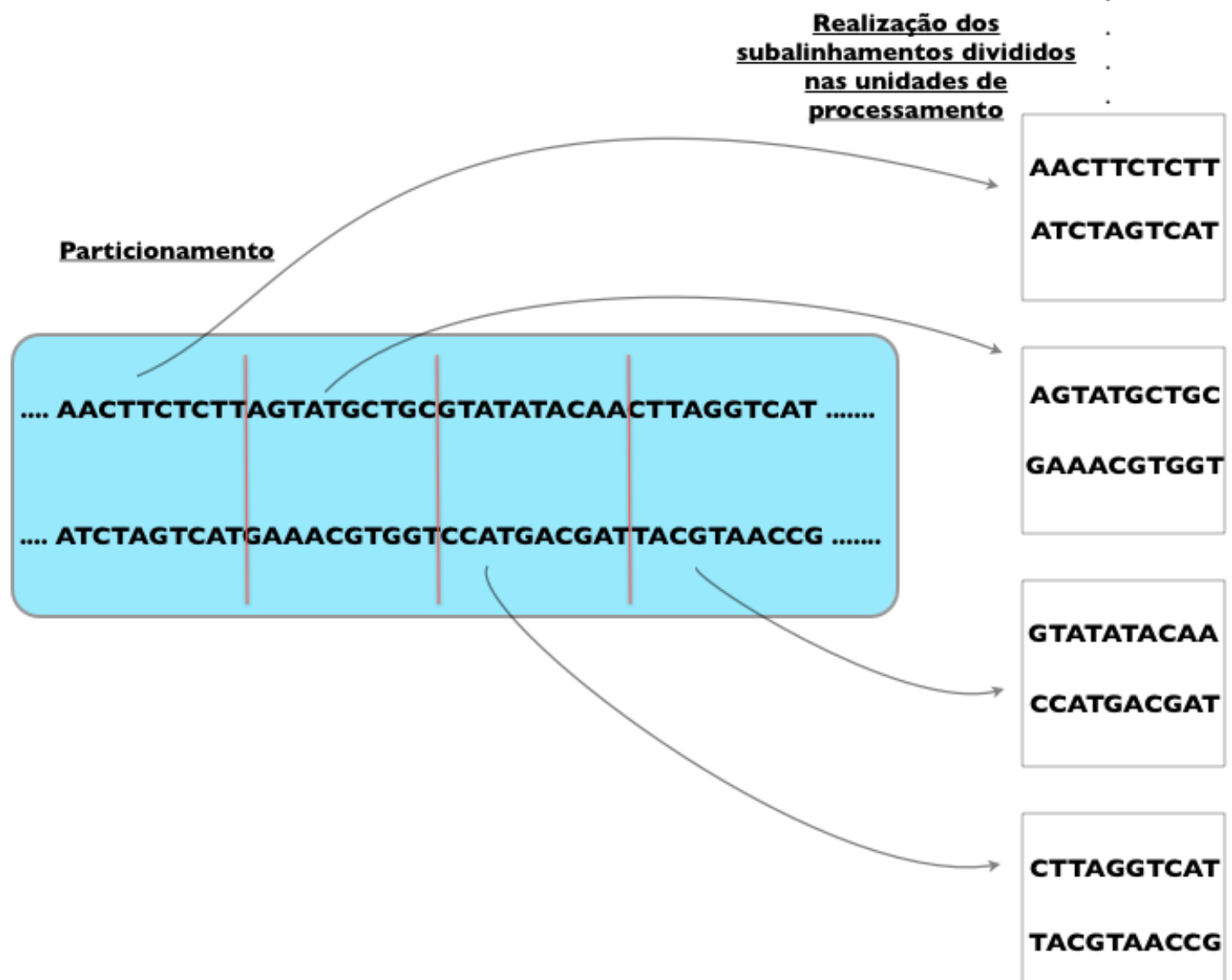


tacionais de alto desempenho que apresentem unidades de processamento com múltiplos núcleos, explora a ampla velocidade dos barramentos locais, sem a necessidade de realizar comunicação na rede para essas pequenas quantidades de dados.

Como um ponto importante a ser reforçado, o procedimento de particionamento direto é válido apenas para pares de sequência que tenham tamanhos iguais. Com isso, é possível garantir que os resultados finais não sejam comprometidos no âmbito biológico, visto que com o uso de algoritmos de alinhamento múltiplos progressivos, sempre haverá um resultado final. No entanto, há a necessidade de assegurar que ele apresente um bom grau de significância biológica.

No entanto, quando não houver a viabilidade de particionamento, será efetuado o alinhamento utilizando-se da técnica de estimativa de pontuações. Dessa forma, temse um conjunto híbrido de estratégias para tratar a fase das construção da matriz de pontuação, podendo a abordagem ser selecionada dinamicamente, durante a sua execução. A ideia do uso de conjuntos híbridos de estratégias, em ambientes computacionais de alto desempenho, apresenta-se como de grande valia na tentativa de obtenção do desempenho máximo de um sistema de computação, além de bons resultados em termos de qualidade final [Díaz et al. 2014, Keller et al. 2011, Pierri, Parisi e Porcelli 2010, Sun et al. 2012, Tommaso et al. 2014].

Ao que se sabe, através de pesquisas extensivas na literatura específica da área, este tipo de particionamento proposto para o presente trabalho, o tratamento das sequências e seu gerenciamento, no contexto do ambiente de sistemas computacionais de alto desempenho, não encontra abordagem similar, na pesquisa realizada. Além disso, a possibilidade da união dessas estratégias com técnicas de otimização, que é melhor explicitada nas seções seguintes, permitindo que múltiplas estratégias operem em conjunto, em alguns casos de forma até concomitante, também não foi encontrada na literatura. 


\subsubsection{Estimativa de Pontuação}

Conforme apresentado anteriormente, na seção 4.3.1, quando as sequências não possuem tamanhos equivalentes, o método de estimativa de pontuações é adotado. Este mecanismo não é mais eficiente do que o mecanismo de particionamento, pois realiza uma quantidade maior de comparações. Porém, para sequências de tamanhos não equivalentes, em que o particionamento não é uma estratégia viável, o método de estimativas de pontuações é adequado, pois é mais eficiente do que a programação dinâmica, cuja utilização é comum nesses casos.

Nessa estratégia, o cálculo da pontuação passa a ocorrer na forma de estágios separados, e aplica-se uma técnica baseada em algoritmos de estimativas de pontuação a cada estágio [Chen et al. 2006].

Do ponto de vista de complexidade computacional, ao não se executar a estratégia de particionamento, devido à não equivalência dos tamanhos das sequências, o algoritmo de estimativas de pontuação é uma estratégia apropriada. A sua complexidade, para duas sequências $\mathrm{X}$ e Y de tamanhos $m$ e $n$, é da ordem de $O(m+n)$. Isto pode ser entendido como um ganho bastante siginificativo em relação à complexidade de ordem $O\left(n^{2}\right)$ da alternativa a ser utilizada por algoritmo de programação dinâmica.

Basicamente, este algoritmo de estimativas de pontuação possui quatro estágios de execução, considerando o sentido de leitura dos pares de sequência, que são: SuperiorEsquerda, Superior-Direita, Inferior-Esquerda, Inferior-Direita. Considera-se a melhor pontuação obtida entre os quatro estágios para ser inserida na matriz de pontuação.

De forma a melhorar o desempenho dessa fase, considerou-se a abordagem desenvolvida por Zafalon [Zafalon 2009], porém com uma modificação na forma de submissão dos processos às unidades de processamento, para utilizar a grande quantidade de recursos disponíveis nos sistemas computacionais de alto desempenho.

Este algoritmo pode ser executado em qualquer quantidade de unidades de processa- 
mento, visto que a distribuição dos estágios é feita em uma fila ordenada. Quatro estágios de pares de sequências são distribuídos às unidades de processamento e, havendo mais unidades disponíveis, os estágios dos próximos pares de sequências na fila também são distribuídos, até que as unidades estejam todas ocupadas. Este procedimento é repetido até que todos os pares de sequência cumpram seus estágios. No algoritmo 4 pode ser visto este mecanismo de controle:

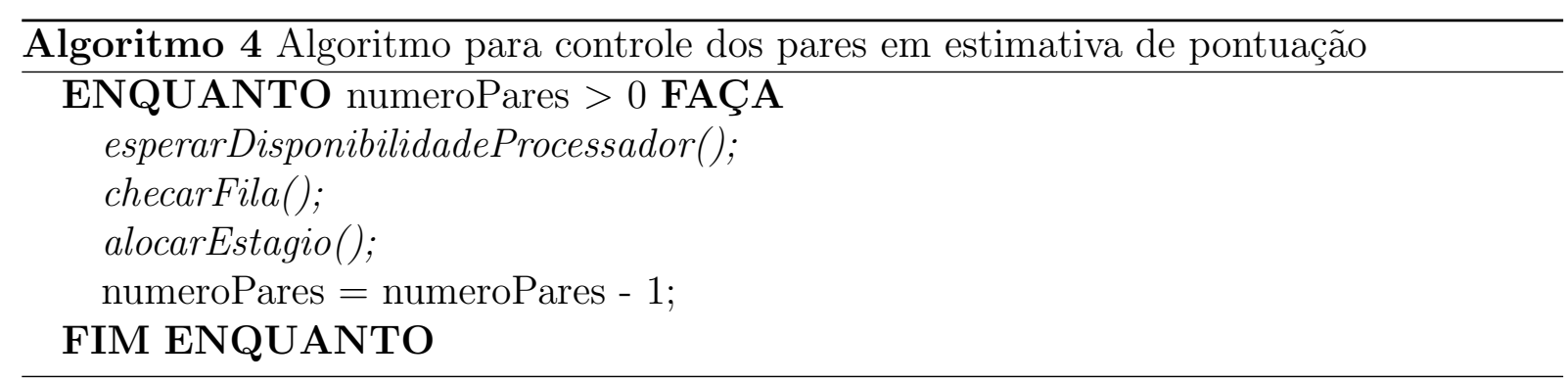

A paralelização dos estágios pode ser vista na figura 14. De modo a entender o funcionamento do algoritmo em cada nó, considere a execução Superior-Esquerda (nó 2). O primeiro caracter mais à esquerda, na sequência superior é marcado (base), neste caso é o caracter $A$. A seguir, são executadas comparações, da esquerda para a direita, deste caracter inicial, com os caracteres da sequência inferior, também começando pelo lado esquerdo. Na medida em que nenhum caracter igual for encontrado, avança-se para o caracter imediatamente à direita do caracter inicial, que neste caso é o $C$, repetindose novamente o processo de comparação, desde o primeiro caracter mais à esquerda da sequência inferior. Quando uma coincidência é encontrada, como é caso com o quarto caracter, da esquerda para a direita, da sequência inferior, marca-se este caracter. Agora, a busca se inicia, tomando como base o caracter $T$, o quinto da esquerda para direita, na sequência inferior e este começa a comparação, com o caracter imediatamente à direita, do antigo caracter base da sequência superior, que neste caso é o $C$. Assim, repete-se essa operação, sucessivamente até o final de uma das sequências. 
Figura 14: Ilustração do particionamento da estimativa de pontos.

Nó 1

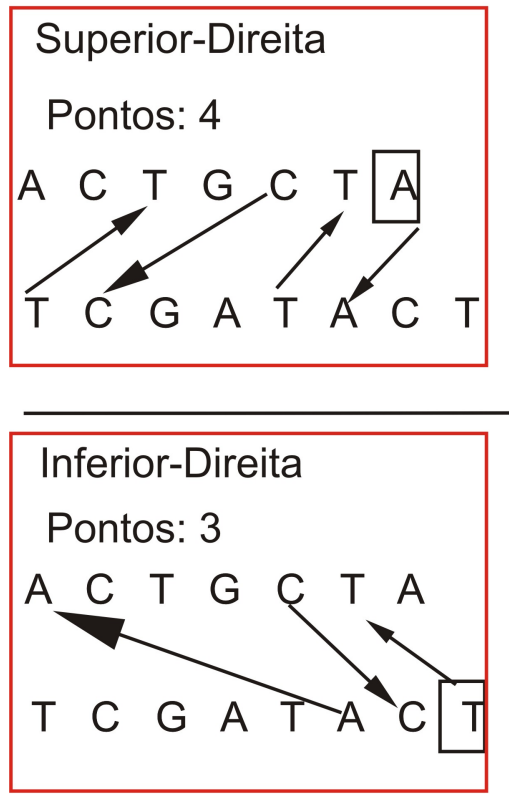

Nó 3
Nó 2

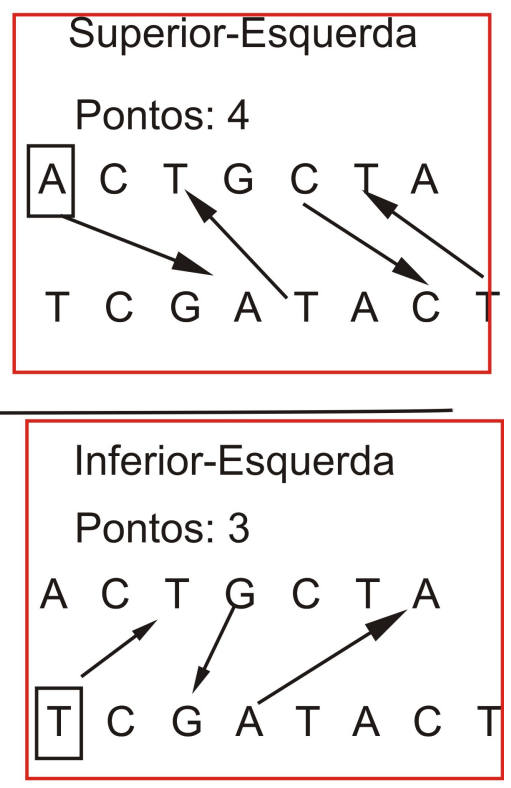

Nó 4

Fonte: Zafalon (2009)

\subsection{Aplicação de Técnicas de Otimização}

O uso de técnicas de otimização, em quaisquer processos em que elas sejam viáveis, apresenta-se, frequentemente, como uma alternativa para melhorar o desempenho de determinadas estratégias e, muitas vezes, melhorar a sua qualidade em termos dos resultados finais obtidos [Chen e Montgomery 2011, DiMaio et al. 2011]. Conforme descrito na seção 2.5, a utilização de técnicas de otimização, em problemas de Bioinformática, mostra-se como uma alternativa bastante viável e com uma demanda crescente no desenvolvimento de aplicações, principalmente devido ao uso corrente de abordagens puramente estocásticas [Rani e Reddy 2012].

No desenvolvimento do presente trabalho, em que o interesse é o estudo e o desenvolvimento de algoritmos paralelos de alinhamento múltiplo de sequências otimizados, para a execução em ambientes de computacionais de alto desempenho, várias estratégias de otimização podem ser empregadas. Estas estratégias podem ser utilizadas não apenas 
para se tentar reduzir ainda mais o tempo de processamento das sequências, possibilitando trabalhar com um número cada vez maior delas, com análises mais complexas e com mais organismos, mas também para tornar os resultados mais precisos e, em muitos casos, com mais qualidade. Dessa forma, o aumento de desempenho das ferramentas e o ganho de qualidade nos resultados finais, dois fatores que em diversos casos são inversamente proporcionais, acabam se aliando quando técnicas de otimização são escolhidas e classificadas corretamente para o escopo do problema destinado [Sun et al. 2012].

As otimizações, através dos algoritmos e estratégias escolhidos, foram aplicadas para melhorar a eficiência do processo de construção da árvore filogenética e para o refinamento da fase de alinhamento múltiplo, e, consequentemente, a qualidade dos resultados finais [Chen et al. 2012, Kim, Pramanik e Chung 1994, Perretto e Lopes 2005, Zomaya 2006]. Além disso, será possível traçar uma comparação bem definida com outras estratégias disponíveis atualmente na literatura, com o objetivo de corroborar a ideia de escolha bem definida dos processos de otimização.

Duas técnicas de otimização foram escolhidas para a aplicação no presente trabalho: uma é a técnica de Ant Colony (Colônia de Formigas) [Dinh et al. 2010], para a construção da árvore filogenética e outra é a de Simulated Annealing [Correa et al. 2012], para a fase de alinhamento múltiplo. A escolha dessas duas técnicas deu-se, principalmente, pela sua ampla aplicação em diversos problemas, especialmente em Bioinformática.

\subsubsection{Construção da Árvore Filogenética}

A técnica de Colônia de Formigas trata-se de uma heurística bioinspirada, que se adequou bastante bem a problemas de Bioinformática.

Basicamente, o uso da técnica de Colônia de Formiga, quando aplicada em problemas de Bioinformática, faz uso de dois parâmetros para que as formigas artificiais possam selecionar os próximos passos (caminhos), durante a execução do algoritmo, que são a distância entre as informações e a intensidade do feromônio. Essa proximidade das in- 
formações, com uma intensidade maior do feromônio, está relacionada aos conceitos de similaridade entre as sequências, ou seja, quanto mais próximas e com feromônio mais intenso, mais similares são essas sequências, tornando, dessa forma, a técnica aplicável em processos de alinhamentos múltiplos de sequências.

No entanto, a estratégia de Colônia de Formigas adotada no desenvolvimento do presente trabalho, classificada como OPACO (On the Intensity of Pheromone Ant Colony Optimization), teve como princípio a retirada do cálculo da distância entre as informações, utilizando, para selecionar o melhor caminho, apenas do fator de intensidade do feromônio [Li et al. 2010, Zhou et al. 2010]. Essa abordagem foi aplicada na construção da árvore filogenética, de modo a gerá-la de maneira mais precisa, além da possibilidade de reduzir a complexidade de tempo e espaço desta parte do algoritmo. Esse tipo de aplicação não foi encontrada na literatura, na revisão bibliográfica realizada. A árvore filogenética, segunda fase do algoritmo de alinhamento múltiplo progressivo, é construída a partir das pontuações obtidas na primeira fase e serve como guia para a terceira fase, que é a de alinhamento múltiplo, a partir das relações de homologia que através dela são encontradas.

Para a seleção do melhor caminho através apenas do uso da intensidade do feromônio, necessita-se do uso de uma estratégia de atualização dinâmica desse feromônio. Para a atualização da intensidade do feromônio, utiliza-se a informação de distância entre os pontos que as formigas percorrerão, visto que em distâncias mais curtas, menos feromônio evaporará e, em distâncias mais longas, ocorrerá o contrário. Assim, descrevem-se, formalmente e matematicamente, os cinco passos do algoritmo OPACO implementado:

Passo 1: inicializar os valores dos parâmetros, como $\alpha$ (peso do feromônio), $\rho$ (parâmetro de decaimento do feromônio), Q (constante positiva do modelo), m (a quantidade de formigas artificiais) e o valor da intensidade do feromônio $\tau_{\mathfrak{i j}}(0)=\tau_{0}$, em que $i$ e j são, respectivamente, os estados de partida e de chegada. Supõe-se que o valor da intensidade do feromônio em cada trecho (distância) do caminho é o mesmo, porém como os comprimentos dos trechos são diferentes, tem-se: $\tau_{0}=\mathrm{Q} / \alpha_{i j}$. 
Passo 2: verifica se uma formiga artificial possui o caminho para todos os demais trechos, ou pontos. Caso a formiga não possua, ela continuará procurando até conseguir encontrar o próximo passo. A regra de transição que o algoritmo utilizará é dada pela equação 4.1, em que se calcula a probabilidade de que uma formiga artificial $z$ qualquer, em um ponto $i$, escolha se movimentar para um ponto $j$, desde que esse ponto $\mathfrak{j}$ pertença aos possíveis pontos disponíveis, em um instante de tempo $t$ qualquer:

$$
P_{i j}^{z}(t)=\frac{\tau_{i j}(t)}{\sum_{j \in \text { possiveis }} \tau_{i j}(t)}
$$

Passo 3: dado que cada formiga artificial tenha alcançado o seu destino predeterminado, ou seja, seguindo o reforço da trilha de feromônio, há a necessidade de atualização dinâmica da intensidade do seu feromônio, conforme descrito pelas equações 4.2 e 4.3, além do recálculo da pontuação, dada pela equação 4.4, que é necessária para a atualização da intensidade do feromônio:

$$
\begin{gathered}
\tau_{i j}(t+1)=(1-\rho) \times \tau_{i j}+\Delta \tau_{i j} \\
\Delta \tau_{i j}=\sum_{z=1}^{m} \Delta \tau_{i j}^{z} \\
\Delta \tau_{i j}^{z}= \begin{cases}\frac{Q \times \eta_{i j} \times\left(\text { potuacao }^{z}+\text { potuacao_Max }\right)}{2}, & \text { se a formiga z passou pelo } \\
0, \text { caso contrário } & \end{cases}
\end{gathered}
$$

$\eta$ trata-se da informação heurística a ser ajustada pelo modelo, durante os testes. Com a atualização dinâmica do feromônio, garante-se um comportamento mais próximo da realidade por parte do algoritmo bioinspirado.

Passo 4: assim que todas as formigas terminaram os seus trajetos, todos os feromônios 
são atualizados novamente, através da equação 4.2 e uma nova rodada de iterações é iniciada.

Passo 5: se o algoritmo encontrar todas as condições necessárias para a parada, então a solução ótima é apresentada e a operação fica encerrada. Caso contrário, um laço de repetição indica o retorno para o passo 2, com o objetivo da realização de novas iterações.

A definição dos parâmetros é algo importante para inicializar a execução do algoritmo. A partir de estudos levantados na literatura, pode-se auferir faixas de valores dos parâmetros, para acelerar o processo de convergência do grafo conexo que é a árvore guia. Assim, alguns parâmetros foram testados e serão apresentados na seção 5, para auxiliar na análise comparativa dos resultados. Para a construção da árvore filogenética, $\alpha$ equivale ao peso da aresta, ou seja, quanto maior o peso, com maior frequência essa aresta é acessada. O parâmetro $\rho$ relaciona-se à frequência de acesso em um determinado ramo, ou seja, o decaimento da intensidade e, por fim, Q representa uma constante que vai balancear o modelo, de modo que a distribuição das formigas pelos ramos seja feita de maneira progressiva, para que elas possam evoluir para as trilhas mais reforçadas e nunca para as menos reforçadas.

No passo 2, inicia-se o processo de varredura nos ramos da árvore, para que o posicionamento dos elementos retirados da matriz de pontuação seja feito de forma correta, ou seja, elementos com pontuação mais similar, sejam alocados de maneira mais próxima nos ramos da árvore. A partir da equação 4.1, os ramos ij da árvore são construídos.

A partir do momento que o ramo é alocado, uma atualização na árvore é realizada, baseando-se no reforço dado à trilha. Assim, esta operação é realizada, se um determinado caminho foi percorrido com mais frequência, a partir da equação 4.4, conforme passo 3.

Quando a busca alcança as folhas, realiza-se uma atualização global da árvore, de forma a balanceá-la, com a atualização de todos os pesos das arestas do grafo, com a nova configuação, a partir da equação 4.2. Quando todos os elementos foram inseridos 
na árvore, ou seja, todos os valores de pontuação dos alinhamentos, o algoritmo termina com a solução ótima.

Sob o aspecto de implementação, a estratégia é descrita no algoritmo 5:

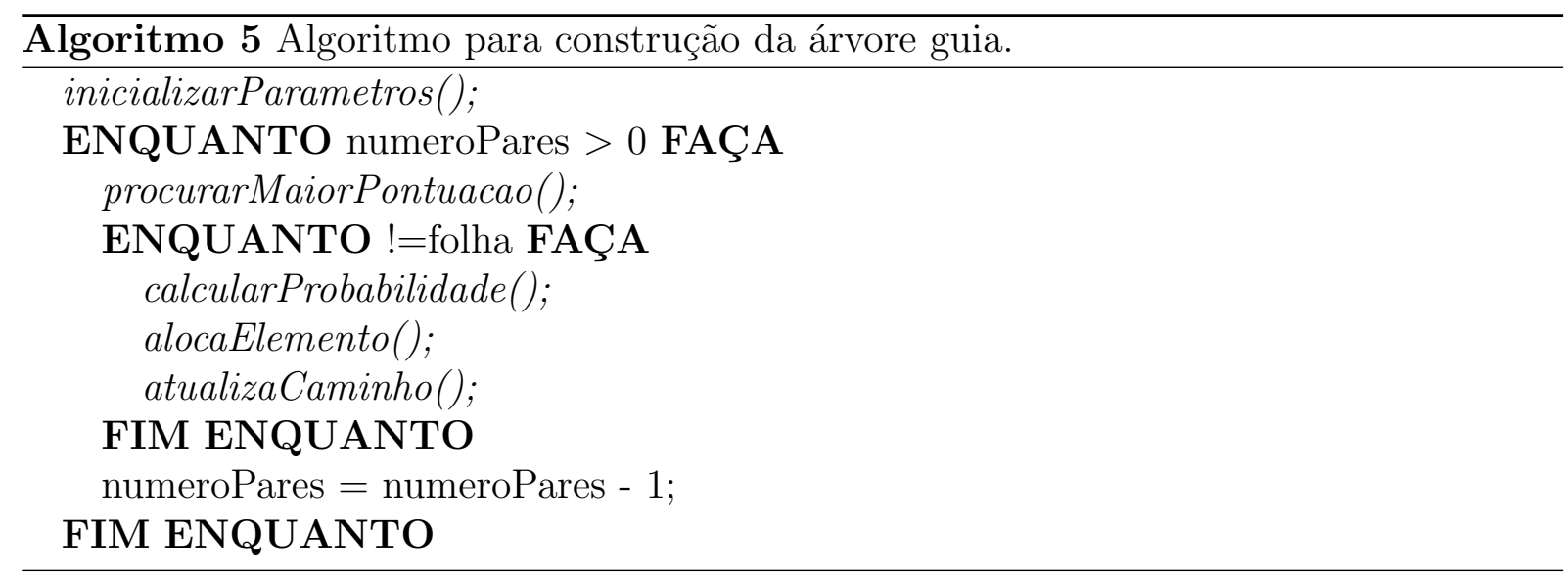

O uso da técnica anteriormente descrita, após a sua execução, é a construção de uma estrutura de árvore semelhante ao que é apresentado na figura 15.

Figura 15: Ilustração da árvore filogenética.

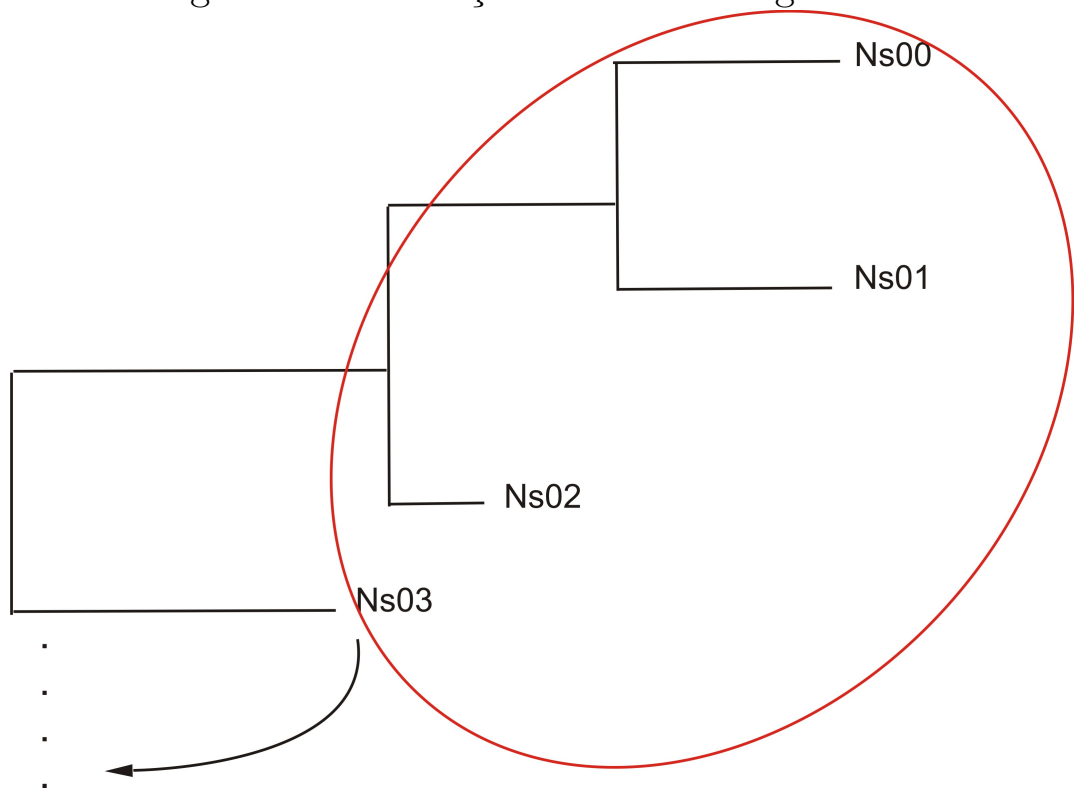

Fonte: Zafalon (2009) 


\subsubsection{Alinhamento Múltiplo Propriamente Dito}

Assim como o algoritmo de Colônia de Formigas, o algoritmo de Simulated Annealing se adaptou de maneira bastante interessante para realizar processos de otimização em problemas de Bioinformática.

O uso do algoritmo de Simulated Annealing relaciona-se, além de sua aplicação em diversos processos de otimização possíveis de serem realizados com ele, com a grande capacidade dessa técnica de promover o refinamento de soluções que se encontram em um bom estado de otimalidade. Dessa forma, é possível aumentar o grau de precisão da solução obtida, através da realização de diversas iterações, pois quanto mais iterações, mais rigorosa se torna a precisão da solução final. No contexto da Bioinformática, trata-se de um processo de grande interesse, pois pode tornar a solução final de um alinhamento mais refinada, trazendo uma significância biológica maior para essa solução. Isto é muito relevante para as análises que podem ser sucedidas, a partir desses alinhamentos produzidos [Ishikawa et al. 1993, Kim, Pramanik e Chung 1994].

Para entrar em consonância com a ideia proposta no presente trabalho, o algoritmo de Simulated Annealing foi aplicado em conjunto com os demais algoritmos apresentados anteriormente, corroborando o princípio de múltiplas estratégias de otimização em um ambiente de computacional de alto desempenho, com o o refinamento das soluções apresentadas pelos outros algoritmos. Além disso, como o algoritmo de Simulated Annealing trata-se de um processo altamente iterativo, demandando um grande tempo de processamento quando executado em ambientes sequenciais, a estratégia de paralelizá-lo, em um ambiente computacional paralelo e distribuído, com abundância de recursos, encaixase perfeitamente nesta proposta. Assim, proveu-se um elevado ganho de desempenho e tornou-se a sua utilização factível e de grande interesse, devido aos resultados finais de alta qualidade.

Conforme aprensentado na seção 2.5.3, o objetivo do algoritmo de Simulated Annealing é uma abordagem para a obtenção de estados mínimos globais de funções. Essa 
minimização tenta estabelecer, após diversas iterações, um estado mínimo ótimo. Esse estado, contextualizado para Bioinformática, enquadra-se como o refinamento da solução de um alinhamento mínimo global ótimo, ou seja, a função objetivo tenta minimizar os erros finais gerados nos alinhamentos, principalmente devido à inserção de gaps e à ocorrência de mismatches.

O funcionamento do algoritmo conta com os seguintes passos:

Passo 1: Considere $X$ um espaço de soluções e $E$ a função objetivo a ser minimizada, com $E: X \rightarrow R$, em que $R$ é um conjunto a ser definido.

Passo 2: Com uma solução inicial $\chi_{0}$, arbitrária, gerada de maneira aleatória, com $x_{0} \in X$, o algoritmo gera, iterativamente, uma sequência de soluções $\left\{x_{n}\right\}_{n=0,1,2,3, \ldots . N}$, tomando as seguintes regras:

1. Modificar a solução corrente $x_{n}$ de maneira aleatória, de modo a prover uma nova solução candidata $x_{n}^{\prime}$.

2. Calcular as mudanças sofridas na função objetivo a ser minimizada, através de sua variação: $\Delta E=E\left(x_{n}^{\prime}\right)-E\left(x_{n}\right)$.

3. Tomando como base o cálculo anterior:

- quando $\Delta \mathrm{E} \leq 0$, a solução candidata a ser aceita é: $x_{n+1}=x_{n}^{\prime}$.

- quando $\Delta \mathrm{E}>0$, aceita-se a solução candidata que apresente a probabilidade $p=\exp \left(-\Delta E / T_{n}\right)$, em que $T_{n}>0$ é um parâmetro de controle, que é a temperatura.

É importante ressaltar que esse decaimento dos valores de temperatura $\left\{T_{n}\right\}_{\mathfrak{n}=0,1,2,3 \ldots}$ trata-se do chamado escalonamento de resfriamento e a adequação correta do seu funcionamento é ponto fundamental para a obtenção de bons resultados, com influência direta no desempenho do algoritmo de Simulated Annealing. A temperatura (T) é o parâmetro que controla a distribuição das soluções $\chi_{n}$ do problema, segundo a distribuição probabilística 
de Boltzmann, que é uma distribuição que atua para convergir para um valor mínimo, conforme o decaimento da temperatura acontece [Torrie e Valleau 1974]. Portanto, tomando por base que o escalonamento de temperatura é fundamental, são apresentados, na fase de testes, alguns resultados obtidos com a implementação feita para os alinhamentos múltiplos de sequências. Os ajustes para bons resultados foram, em geral, alcançados a partir de execuções exaustivas, inicialmente, a partir do método de tentativa e erro, baseando-se em parâmetros comumente utilizados na literatura.

Na abordagem proposta para o uso do algoritmo de Simulated Annealing, para o presente trabalho, a ideia foi tratar paralelamente o refinamento das soluções, com a utilização de diferentes valores de temperaturas e as iterações para os cálculos de novos estados divididos entre as diversas unidades de processamento, possibilitando um aumento significativo da vazão do algoritmo.

Inicialmente, utilizou-se uma regra para o escalonamento das temperaturas, executada nas diversas unidades de processamento existentes, de modo que cada uma dessas temperaturas puderam ser utilizadas no recálculo da variação de energia, no processo de resfriamento (annealing). Quanto mais recálculos realizados, mais precisa é a solução final. A equação 4.5 apresenta a regra de escalonamento de temperatura:

$$
\mathrm{T}_{\mathrm{n}}=\alpha^{(\mathrm{n} / \mathrm{K})} \times \mathrm{T}_{0}
$$

com $\mathrm{n}=1,2,3, \ldots, \mathrm{N} ; 0<\alpha<1 ; \mathrm{K}>>1$, sendo $\mathrm{T}_{0}, \mathrm{~T}_{\mathrm{N}}$ e $\mathrm{K}$, parâmetros a serem escolhidos [Kirkpatrick, Gelatt e Vecchi 1983].

Cada unidade de processamento participante, a partir da sua temperatura calculada localmente, ou seja, uma solução inicial constante, passa à realização do seu processo de resfriamento. Depois de $k$ passos do resfriamento realizados, com k a ser definido, as unidades de processamento são agrupadas par-a-par, para trocarem as soluções. Essa troca é calculada por uma regra probabilística, entre as duas soluções, mostrada na equação 4.6: 


$$
p\left(T, E, T^{\prime}, E^{\prime}\right)=\left\{\begin{array}{l}
1, \text { se } \Delta T \times \Delta E<0 \\
\exp \left(-\frac{\Delta T \times \Delta E}{T \times T^{\prime}}\right), \text { caso contrário }
\end{array}\right.
$$

em que E, T, E’ e T', são, respectivamente, as energias e temperaturas de cada elemento do par, com $\Delta \mathrm{T}=\mathrm{T}^{\prime}-\mathrm{T}$ e $\Delta \mathrm{E}=\mathrm{E}^{\prime}-\mathrm{E}$.

A troca de soluções entre as unidades de processamento com diferentes temperaturas é basicamente a mudança de temperatura entre elas, com o objetivo de buscar a menor temperatura. Dessa forma, o cálculo da probabilidade indicará quais unidades realizarão troca, privilegiando aquelas com menor temperatura, pois a probabilidade resultante será maior.

Para os alinhamentos múltiplos obtidos, a função de energia (E) a ser calculada é computada a partir das somas das pontuações de alinhamento de todas as sequências do alinhamento múltiplo. Para obtenção de bons resultados, esta função $E$ deve ter o seu valor diminuindo a cada passo do resfriamento, ou seja, convergindo para um rearranjo ideal para o alinhamento. A temperatura T é reduzida a cada nova iteração, quando mais coincidências acontecem entre as sequências rearranjadas, ou seja, convergindo para que sequências mais semelhantes sejam alocadas mais próximas.

Nas figuras 16 e 17 pode ser verificada uma ilustração da condução do alinhamento múltiplo, conforme ocorre nas unidades de processamento. A ideia sobre o seu funcionamento está relacionada com a necessidade de encontrar coincidências entre as sequências. Para ilustrar, considerou-se $N$ sequências, variando-se de $A_{0}, \ldots, A_{N-1}$. Compara-se $A_{0}[0]$, com o primeiro caracter de todas as sequências do conjunto $A_{1}, \ldots, A_{N-1}$. Assim, realiza-se o mesmo procedimento para $A_{i}$, sendo $i=1,2, \ldots, n$-1, e seleciona-se um caracter $A_{i}[j]$. Utilizando-se de combinação de probabilidades determinadas pela pontuação de comparações feitas com a posição $A_{0}[0]$, dos desvios calculados entre a sua localização com relação à posição $A_{0}[0]$ e da variação de energia $(\Delta E)$ entre $A_{i}[j]$ e $A_{0}[0]$, produz-se o rearranjo das sequências, visto que o objetivo é o alinhamento final. Eventualmente, 
pode-se proceder a inserção de espaços (gaps), como forma de reajuste das sequências. Este passo é repetido para $A_{0}[1], A_{0}[2]$, até $A_{0}\left[\left|A_{0}\right|-1\right]$.

A cada nova iteração, novas sequências são inseridas para serem comparadas com o conjunto alinhado existente, baseando-se na proximidade de sua localização na árvore guia, ou seja, quanto mais próxima das sequências anteriormente alinhadas, mais breve essa sequência será alinhada.

Figura 16: Ilustração da execução do alinhamento múltiplo em um primeiro passo.

[0] [1] [2] [3] [4] [5] [6] [7] [8] [9] [10] .....

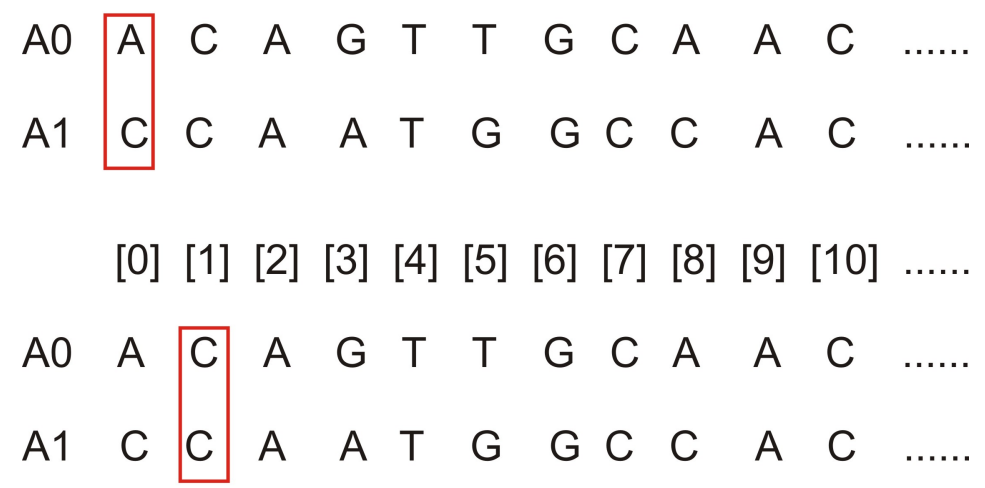

[0] [1] [2] [3] [4] [5] [6] [7] [8] [9] [10] .....

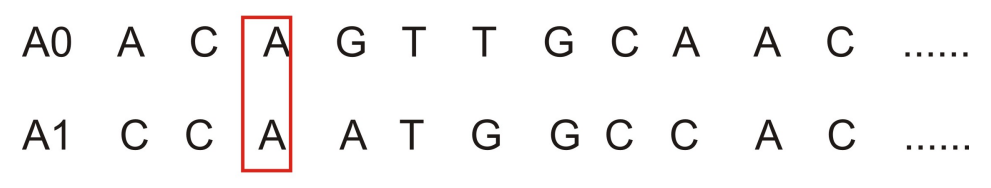

[0] [1] [2] [3] [4] [5] [6] [7] [8] [9] [10]

\begin{tabular}{llll|llllllll}
$A 0$ & $A$ & $C$ & $A$ & $G$ & $T$ & $T$ & $G$ & $C$ & $A$ & $A$ & $C$ \\
$A 1$ & $C$ & $C$ & $A$ & $A$ & $T$ & $G$ & $G$ & $C$ & $C$ & $A$ & $C$
\end{tabular}

Fonte: Zafalon (2009)

Sob o ponto de vista de implementação, a estratégia é descrita, a seguir, no algoritmo 6:

Manteve-se, no algoritmo 6, a mesma nomenclatura dos elementos apresentada na descrição da estratégia. Vale ressaltar que a geração de novos estados $X_{i}$ relaciona-se a 
Figura 17: Ilustração da execução do alinhamento múltiplo em um segundo passo.

[0] [1] [2] [3] [4] [5] [6] [7] [8] [9] [10] .....

$\begin{array}{llllllllllllll}A 0 & A & C & A & G & T & T & G & C & A & A & C & \ldots . . . \\ A & \text { A } & C & C & A & A & T & G & G & C & C & A & C & \ldots . . \\ A & A & C & G & G & T & C & C & C & G & A & G & \ldots . .\end{array}$

[0] [1] [2] [3] [4] [5] [6] [7] [8] [9] [10] ......

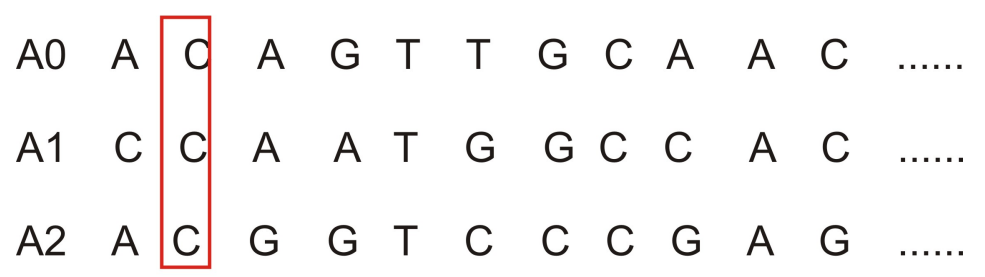

[0] [1] [2] [3] [4] [5] [6] [7] [8] [9] [10] .....

\begin{tabular}{lll|llllllllll}
$A 0$ & $A$ & $C$ & $A$ & $G$ & $T$ & $T$ & $G$ & $C$ & $A$ & $A$ & $C$ & $\ldots . .$. \\
$A 1$ & $C$ & $C$ & $A$ & $A$ & $T$ & $G$ & $G$ & $C$ & $C$ & $A$ & $C$ & $\ldots .$. \\
$A 2$ & $A$ & $C$ & $G$ & $G$ & $T$ & $C$ & $C$ & $C$ & $G$ & $A$ & $G$ & $\ldots .$.
\end{tabular}

Fonte: Zafalon (2009)

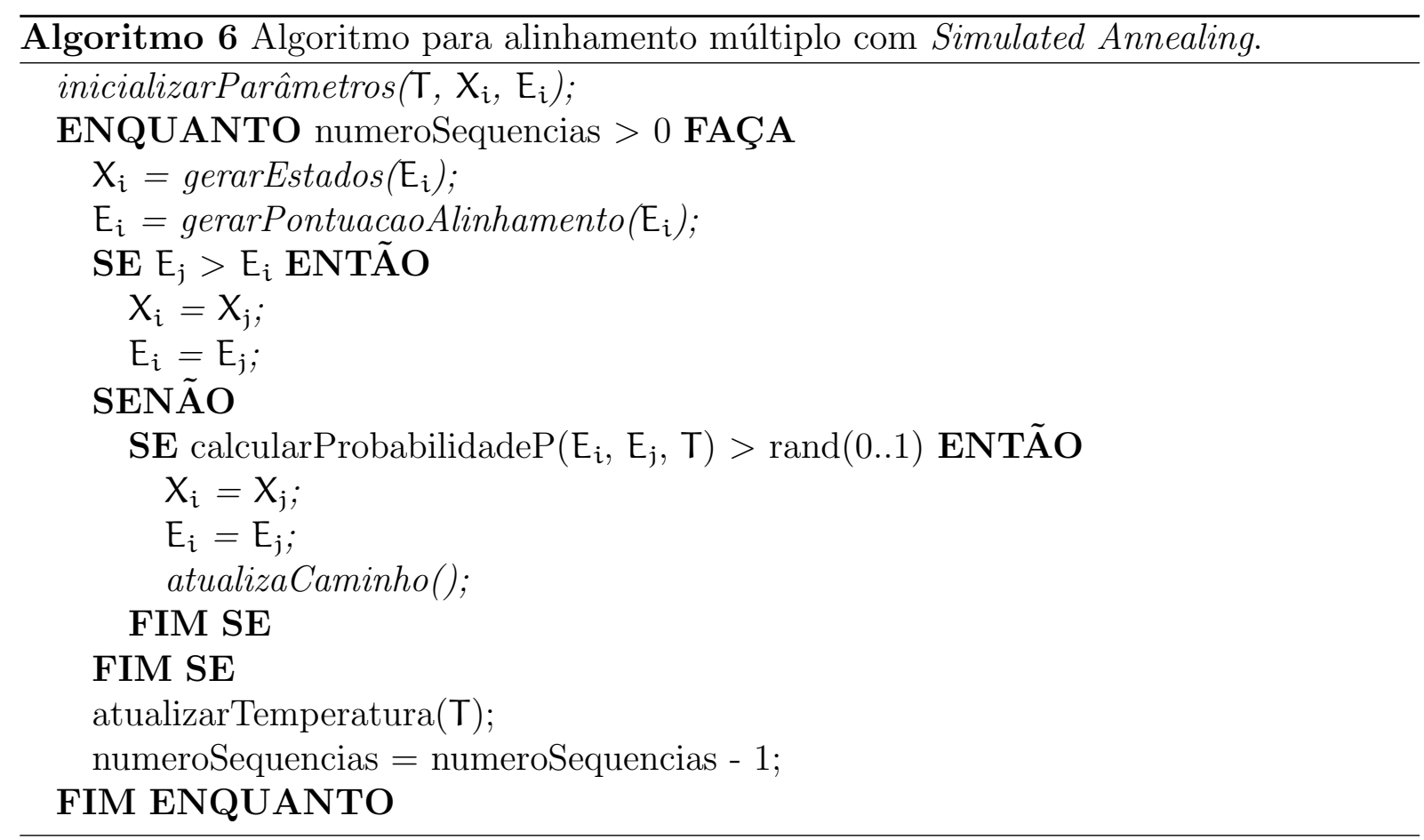


uma nova possibilidade de alinhamento, ou seja, após um rearranjo, uma nova solução é obtida, o que é parte de uma estratégia de refinamento de soluções.

Os resultados obtidos a partir das execuções que foram realizadas são apresentados no capítulo 5, além de análises que ajudam a corroborar o ganho de desempenho das inovações desenvolvidas e as suas qualidades. 


\section{Implementação, testes e análises}

No presente capítulo, são apresentadas a forma como a ferramenta foi implementa, as infraestruturas em que os testes de desempenho e qualidade foram conduzidos, bem como os resultados obtidos com as execuções e suas análises.

\subsection{Implementação}

Na implementação da ferramenta do presente trabalho, utilizou-se como base o código fonte desenvolvido por Zafalon [Zafalon 2009], apresentado na seção 3.7. Como a abordagem adotada no trabalho de Zafalon [Zafalon 2009] também se baseia no algoritmo de alinhamento múltiplo progressivo, a migração de código tornou-se viável para a implementação da ferramenta do presente trabalho.

Inicialmente, implementou-se a nova estratégia para a realização do cálculo da matriz de pontuações, utilizando a paralelização e o particionamento paralelo dos pares de sequências.

Posteriormente, desenvolveu-se um novo método de construção da árvore filogenética, através da heurística bioinspirada de colônia de formigas, o que possibilitou a construção dessa estrutura de maneira mais eficiente e com mais qualidade.

Finalmente, na última fase, implementou-se um novo método de alinhamento múltiplo, utilizando-se a heurística de otimização de simulated annealing paralela. Com isso, foi possível refinar os resultados produzidos nesta fase, além de garantir um bom desempenho 
em termos de tempo de execução.

A combinação dos três novos métodos integrados possibilitou que o desenvolvimento de uma ferramenta que se utiliza de estratégias híbridas, totalmente nova, e que permitiu tanto o ganho de desempenho, quanto a melhora da qualidade dos alinhamento finais produzidos.

\subsection{Infraestrutura utilizada}

No contexto da infraestrutura provida para a concepção e execução dos testes do presente projeto, utilizou-se o GridUnesp do Núcleo de Computação Científica (NCC) ${ }^{1}$ da Unesp.

Esse ambiente foi escolhido devido à facilidade de acesso e à possibilidade de realização de testes diversos, sem muitos impedimentos técnicos. Um segundo motivo a ser elencado para esta escolha relaciona-se à possibilidade de validar os algoritmos e a sua capacidade de adaptação em um ambiente que pode variar o seu porte, melhorando as características de portabilidade desses algoritmos. Além disso, este ambiente oferece condições técnicas suficientes para a execução dos testes e instalação de bibliotecas de software, caso necessário. Na seção 5.2.1, descreve-se a infraestrutura do ambiente deste teste.

É importante salientar, conforme é descrito nas seções seguintes, que um teste inicial foi conduzido em uma máquina sequencial, que é um MacBook Pro, com processador Intel Core 2 Duo de 2,26Ghz, com 4GB de memória RAM, executando MAC OS X 10.6.8. Isto foi realizado, de modo a corroborar que a ferramenta desenvolvida apresentasse um comportamento coerente mesmo quando executada em um computador pessoal.

\subsubsection{GridUnesp}

O GridUnesp trata-se de um sistemas computacional com 386 servidores, 200 TB de capacidade de armazenamento e uma infraestrutura avançada de comunicação entre os

\footnotetext{
${ }^{1}$ http://www.unesp.br/grid
} 
seus clusters. O projeto foi concebido sob uma arquitetura hierárquica de duas camadas, que inclui um cluster central na cidade de São Paulo, e sete clusters secundários, sendo que seis deles estão nos campi da Unesp no interior do estado de São Paulo e um encontra-se na capital, junto ao cluster central.

O cluster central possui 2048 núcleos de processamento com arquitetura Intel Xeon quad-core, alcançando a capacidade máxima de processamento de 23.2 TFlops. Cada nó escravo possui dois processadores Intel Xeon quad-core modelo E5440, de $2.83 \mathrm{GHz}$, com 16 GB de memória e 73 GB de armazenamento. Os nós servidores principais contam com quatro processadores Intel Xeon quad-core modelo E7340, de $2.4 \mathrm{GHz}$, com $32 \mathrm{~GB}$ de memória e quatro discos de 146 GB de capacidade de armazenamento. O sistema de rede de área de armazenamento (SAN) conta com quatro canais de fibra óptica de 4 Gbps e 36 TB de capacidade de armazenamento. Além disso, o sistema conta, ainda, com 4 servidores de dados híbridos com quarenta e oito discos de 500 GB cada, totalizando 96 TB de capacidade de armazenamento. Os nós escravos e os nós servidores principais estão interconectados por uma rede Ethernet Gigabit para tráfego de dados TCP/IP e uma rede Fast Ethernet dedicada para gerenciamento. Os nós servidores estão interconectados por um switch Infiniband de alto desempenho, que trabalha com taxas de até 20 Gbps em canal duplo. Por fim, possui quatro servidores dedicados para o desenvolvimento e teste de aplicações, antes que elas sejam executadas no ambiente de grade. Apresenta-se na figura 18 as conectividades do cluster central da grade [Iope, Lemke e Winckler 2010].

Com relação aos clusters secundários, eles são compostos por dezesseis nós escravos e dois nós controladores, oferecendo 128 núcleos de processamento. Os nós escravos, pertencentes aos clusters secundários, são idênticos aos nós escravos do cluster central. Esse cluster secundário conta com uma SAN de 12 TB de capacidade. Para o tráfego TCP/IP regular, ele conta com um switch Gigabit Ethernet de 24 portas e para o controle fora de banda, com um switch Fast Ethernet dedicado, também de 24 portas. Todos os clusters secudários contam com dois nós principais para gerenciamento, que permitem que o monitoramento e controle sejam feitos de forma remota. Além disso, ele possui dois nós 
Figura 18: Cluster central do GridUnesp.

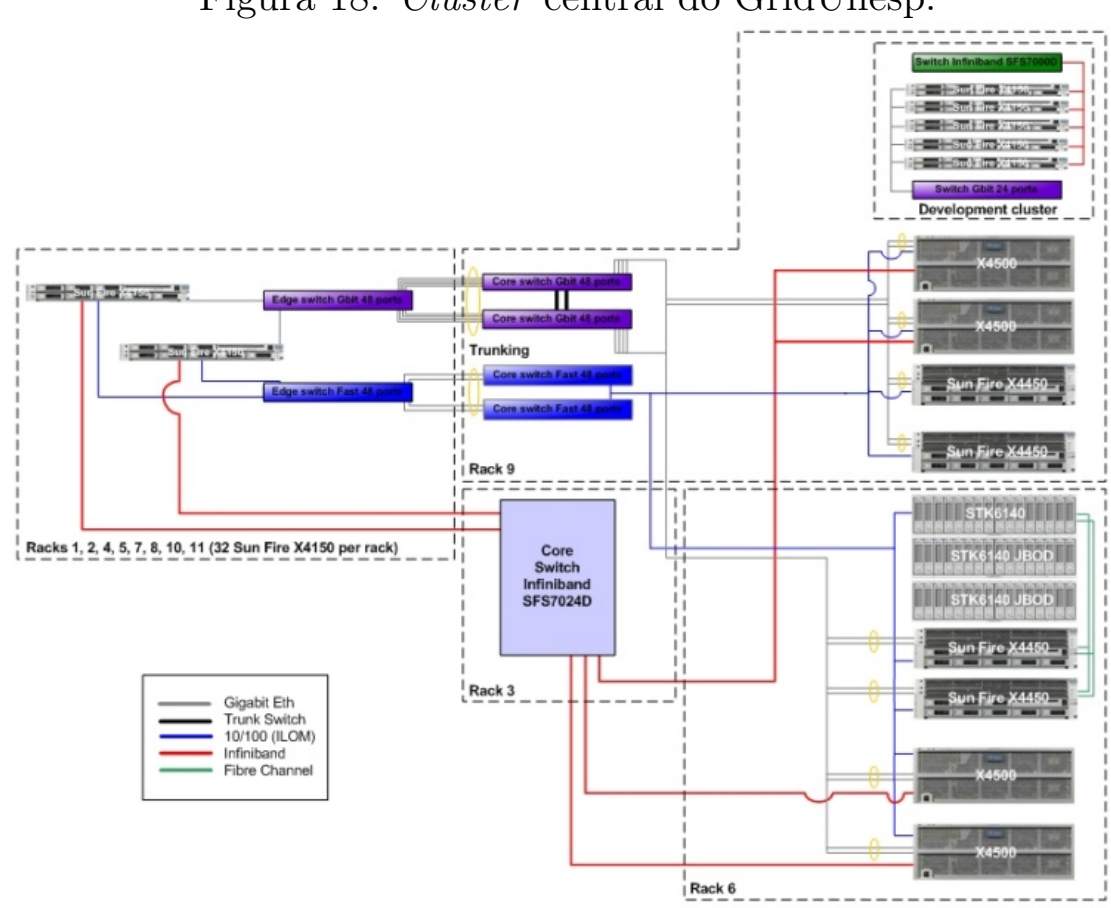

Fonte: Iope, Lemke e Winckler (2010)

servidores para desenvolvimento, com as mesmas características dos nós de desenvolvimento do cluster central [Iope, Lemke e Winckler 2010].

Geralmente, no suporte à comunicação de grades computacionais, utiliza-se à Internet como a rede principal. Porém, a Internet possui vários problemas com relação a atrasos que dificultam o uso eficiente e efetivo de recursos remotos e a manipulação de grandes massas de dados. Dessa maneira, o GridUnesp, aproveitando-se da infraestrutura provida pelo projeto KyaTera da FAPESP ${ }^{2}$, no Estado de São Paulo, pode ser composto sob uma infraestrutura de comunicação em canais de fibra óptica de 1 Gbps e 10 Gbps, permitindo que as informações entre os clusters possam ser trocadas com qualidade e alta velocidade, reduzindo os problemas de latência. Na figura 19, pode-se verificar a infraestrutura de comunicação do GridUnesp executando sobre os canais do projeto KyaTera, passando por diversas cidades, bem como a descrição da velocidade do canal, em cada uma delas [Iope, Lemke e Winckler 2010].

\footnotetext{
${ }^{2}$ http://www.kyatera.fapesp.br/
} 
Figura 19: Projeto KyaTera.

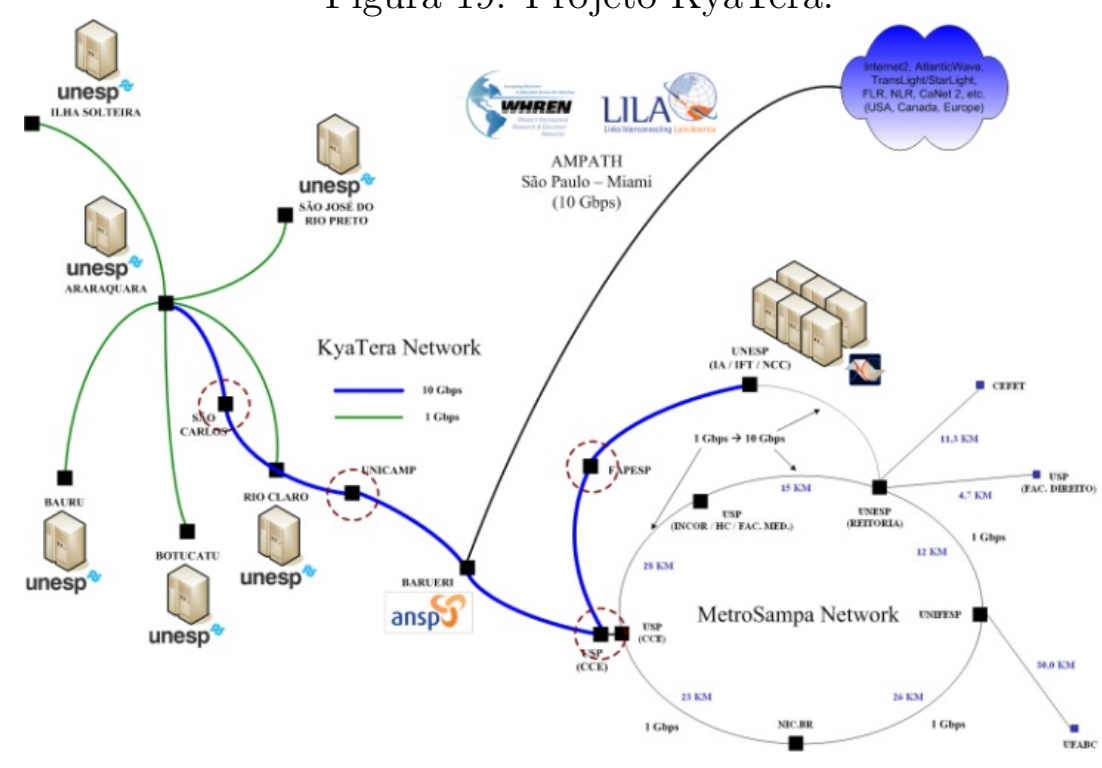

Fonte: Iope, Lemke e Winckler (2010)

Por fim, vale a pena apresentar a infraestrutura de software que se encontra operacional no GridUnesp. Utiliza-se um serviço de acesso a diretórios baseado em OpenLDAP 3 e todas as informações pertinentes aos usuários e seus respectivos hosts são armazenados em um repositório no cluster central, regularmente replicado para os repositórios dos clusters secundários. No que tange ao sistema operacional, todos os servidores executam CentOS ${ }^{4}$, com o escalonador Condor [Litzkow, Livny e Mutka 1998] ${ }^{5}$ com suporte para MPI [Pacheco 1997].

O GridUnesp utiliza o middleware OSG (Open Science Grid) ${ }^{6}$ para integrar os recursos e compartilhá-los. O middleware OSG compreende as camadas de software que vão da plataforma de hardware até a camada de aplicação, gerenciando um grande número de protocolos padrão e interfaces, através do seu complexo sistema de software centrado no Globus [Foster e Kesselman 1997] ${ }^{7}$ e no Condor.

\footnotetext{
${ }^{3}$ http://www.openldap.org/

${ }^{4}$ http://www.centos.org/

${ }^{5}$ http://research.cs.wisc.edu/condor/

${ }^{6}$ https://www.opensciencegrid.org/bin/view

${ }^{7}$ http://www.globus.org/
} 


\subsubsection{Ferramentas utilizadas}

Sob o ponto de vista de desenvolvimento, a ferramenta de alinhamento múltiplo proposta no presente projeto foi implementada em linguagem $\mathrm{C}$, utilizando-se para a comunicação a biblioteca MPICH2. A opção pela linguagem de programação e pela biblioteca de comunicação deve-se à robustez que ambas oferecem, além de serem amplamente utilizadas em aplicações em Bioinformática. Além disso, grande parte dos sistemas computacionais de alto desempenho oferecem suporte a esta linguagem de programação e à biblioteca de comunicação utilizadas.

O código foi compilado em gcc para todos os testes, com um detalhe para a compilação realizada no GridUnesp, em que o gcc possui fatores de otimização de instruções para processadores Intel.

As execuções no GridUnesp basearam-se na construção de um script para submissão, em que todos os parâmetros de trabalho são informados. No ambiente de teste sequencial, utilizou-se linhas de comando em um terminal para invocar a execução da ferramenta.

\subsubsection{Metodologia de testes}

Para a realização dos testes do presente trabalho, adotou-se a execução de dez vezes para cada caso de teste. Esta quantidade de vezes foi escolhida para que se obtivesse uma medida estatística confiável para a análise de dispersão dos resultados, tanto sob a vertente dos testes de desempenho, quanto dos testes de qualidade.

Nos testes de desempenho da ferramenta foi possível a obtenção de um valor médio dos tempos de execução, bem como os valores de desvio padrão destes tempos. Com isso, possibilitou-se uma avaliação mais precisa do comportamento da ferramenta em diferentes cenários.

Com relação aos testes de qualidade também extraiu-se um valor médio da significância biológica dos resultados finais obtidos, além dos valores máximos e mínimos absolutos, 
em cada caso de teste.

\subsection{Testes de desempenho}

Nesta seção, são apresentados os testes de desempenho realizados. Estes testes são importantes para corroborar a capacidade de redução de tempo de execução da ferramenta desenvolvida.

Apresentam-se testes de desempenho para as três fases, que são: a construção da matriz de pontuação (primeira fase), a construção da árvore filogenética (segunda fase) e realização do alinhamento múltiplo (terceira fase). Além disso, compara-se os resultados obtidos com outra ferramenta bastante conhecida e utilizada na área de Bioinformática, como será descrito nas seções a seguir.

\subsubsection{Matriz de pontuação}

Testes de desempenho foram realizados para avaliar os ganhos de desempenho promovidos pelas estratégias propostas.

Durante a execução desses testes, variou-se a quantidade de unidades de processamento participantes, a quantidade de sequências a serem analisadas e os tipos dessas sequências (nucleotídeos e proteínas). Todos estes fatores de variação propostos são importantes, pois são itens que, além de permitirem uma análise do panorama geral do desempenho, auxiliam, posteriormente, na análise da qualidade dos resultados, pois generalizou-se a solução para nucleotídeos e proteínas.

Em todos os gráficos para a aferição de desempenho, apresenta-se o número de unidades de processamento, no eixo das abscissas, e, o tempo, em segundos, no eixo das ordenadas.

Para comparar o desempenho da ferramenta no presente trabalho, utilizou-se uma 
ferramenta de alinhamento múltiplo bem conhecida, que é a ClustalW-MPI ${ }^{8}$ [Li 2003]. Trata-se de uma ferramenta que faz uso, também, de uma abordagem progressiva e sua paralelização acontece na primeira fase, que é a construção da matriz de pontuação. A sua escolha deu-se, pois a ClustalW-MPI é utilizada frequentemente em trabalhos na área de Bioinformática, para comparações com diversas novas abordagens propostas. Nos resultados que são apresentados a seguir, a ClustalW-MPI é denominada abordagem sem particionamento.

Conforme pode ser visto no gráfico da figura 20, um primeiro teste, de pequeno porte, foi conduzido com um conjunto de 4 sequências de aminoácidos, todas com tamanhos equivalentes, cada uma com 200 aminoácidos. Estas sequências foram retiradas da base de dados do SBI (Swiss Bioinformatics Institute) ${ }^{9}$. Este teste foi realizado, de modo a verificar se o funcionamento da nova proposta está correto, atendendo às necessidades de redução drástica de tempo de execução da primeira fase do algoritmo de alinhamento múltiplo progressivo, que é a fase de cálculo das pontuações para serem inseridas na matriz de pontuação. É importante salientar que este teste inicial foi conduzido em um computador pessoal, que contém 2 núcleos de processamento, processando com múltiplos processos, conforme descrito na seção 5.2.

Figura 20: Execução da construção da matriz de pontuação, com conjunto de 4 sequências de aminoácidos, com 200 aminoácidos cada.

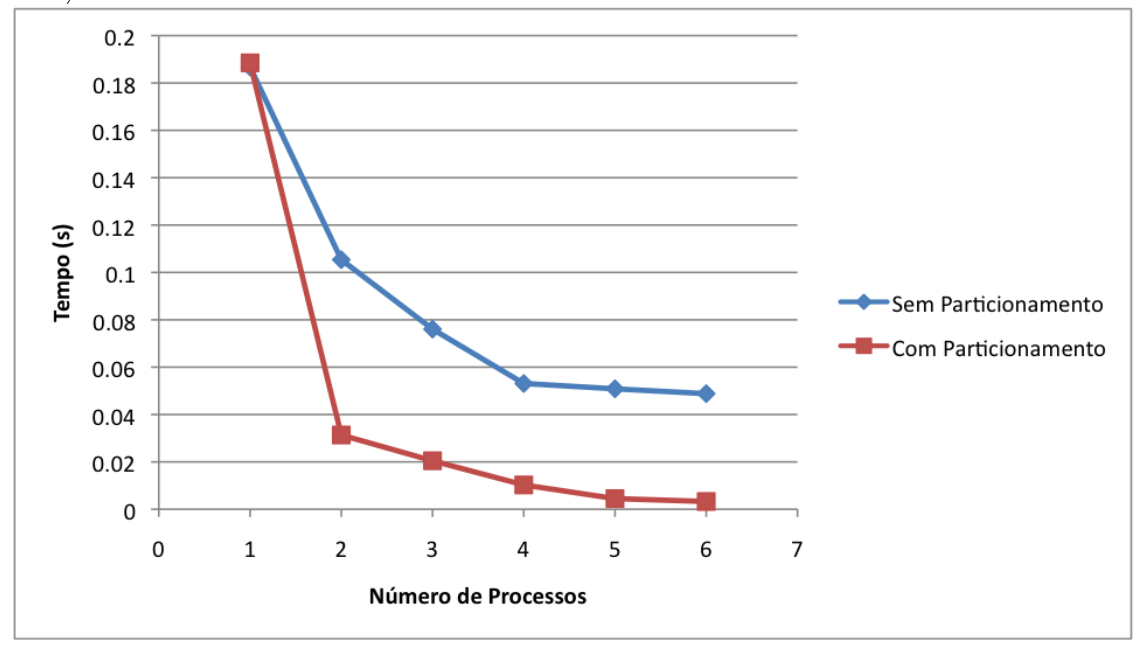

\footnotetext{
${ }^{8}$ http://www.bii.a-star.edu.sg/software/clustalw-mpi/

${ }^{9}$ http://www.expasy.org/
} 
Percebe-se, pelo gráfico da figura 20, que a redução de tempo começa a ficar significativa, a partir do momento que a estratégia de particionamento é acionada, com dois processos. Assim, a regra de quebra descrita na seção 4.3.1 subdivide as sequências, promovendo uma queda brusca no tempo de processamento. Analisando-se todos os casos do gráfico da figura 20, houve uma redução média do tempo de processamento da ordem de 74\%. O ganho de desempenho de um para dois processos, da versão com particionamento, foi da ordem de 6,01. Na ausência de uma versão sequencial, adotou-se a execução com um processo como sequencial, pois praticamente inexiste overhead de comunicação. Por fim, calculou-se o desvio padrão máximo do tempo de execução, que foi da ordem de 0,002.

Por se tratar de um problema NP-completo, pode-se explicar esta queda acentuada no tempo de processamento, pois, a partir de dois processos, além de uma redução no tempo de processamento promovida pela paralelização do alinhamento par-a-par, ocorre ainda o particionamento das sequências, reduzindo-se o comprimento do par a ser tratado. A redução do tamanho do par de sequências é ponto crítico para que o tempo do algoritmo de programação dinâmica seja reduzido, além do que, agrega-se a isso, a execução das partições também em paralelo.

Considerando agora a execução completa da ferramenta de alinhamento múltiplo, ou seja, de todas as três fases são executadas para o mesmo caso de teste, pode-se observar, pelo gráfico da figura 21, uma consequente redução global do tempo de execução. Analisando-se todas as execuções, houve uma redução global média da ordem de $16 \%$ do tempo de processamento.

Os próximos quatro testes apresentados foram todos realizados com conjuntos de sequências de nucleotídeos. Estes foram escolhidos devido aos grandes conjuntos de sequências que podem ser obtidos, tanto em número de sequências, quanto em comprimento dessas sequências. Retirou-se esses conjuntos da base de dados do NCBI (National Center for Biotechnology Information ${ }^{10}$. Para auferir o ganho promovido pela ferramenta proposta no presente trabalho, executou-se os testes dentro do GridUnesp, variando-se as

\footnotetext{
${ }^{10}$ http://www.ncbi.nlm.nih.gov/
} 
Figura 21: Execução de todas as fases da ferramenta de alinhamento, com conjunto de 4 sequências de aminoácidos, com 200 aminoácidos cada.

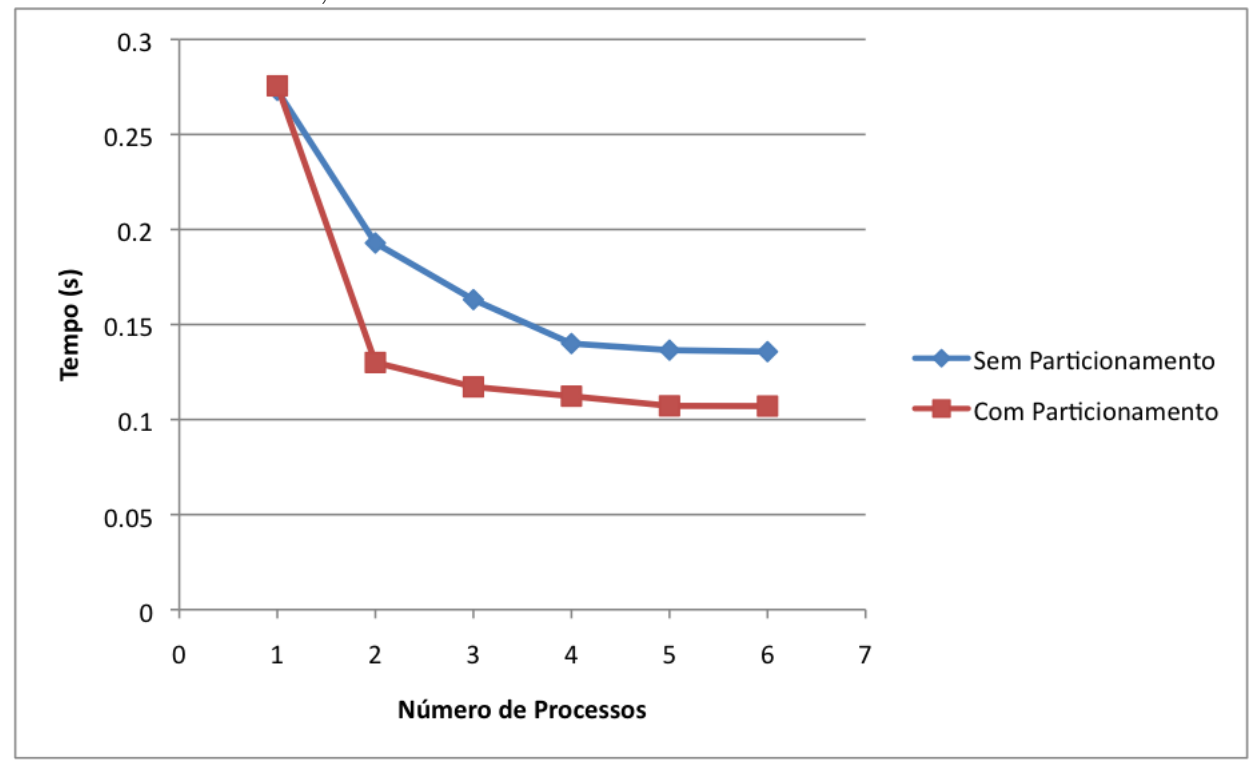

quantidades de unidades processamento, com 2, 4, 8, 16, 32, 64 e 128 processadores, de modo a verificar a escalabilidade da estratégia implementada na ferramenta.

O segundo teste foi conduzido com um conjunto de 400 sequências de nucleotídeos e cada sequência possuindo 500 pares de bases (comprimento). No gráfico da figura 22, apresenta-se o resultado da fase de construção da matriz de pontuação e percebese uma redução significativa no tempo de processamento, desde o primeiro caso, com 2 processadores. Além disso, é verificada uma queda acentuada no início devido à técnica de particionamento, o que se mantém com o aumento do número de processos, porém de uma maneira suavizada, reforçando a estabilidade do método. Em uma análise de todos os casos, houve uma redução média do tempo de processamento da ordem de $78 \%$. O ganho de desempenho de um para dois processos, da versão com particionamento, foi da ordem de 5,37. Novamente, na ausência de uma versão sequencial, adotou-se a execução com um processo como sequencial, reafirmando-se que, praticamente, inexiste overhead de comunicação. Por fim, calculou-se o desvio padrão máximo do tempo de execução, que foi da ordem de 2,24 .

Na execução completa da ferramenta, pode-se observar pelo gráfico da figura 23 que 
Figura 22: Execução da construção da matriz de pontuação, com um conjunto de 400 sequências de nucleotídeos, com 500 pares de bases cada.

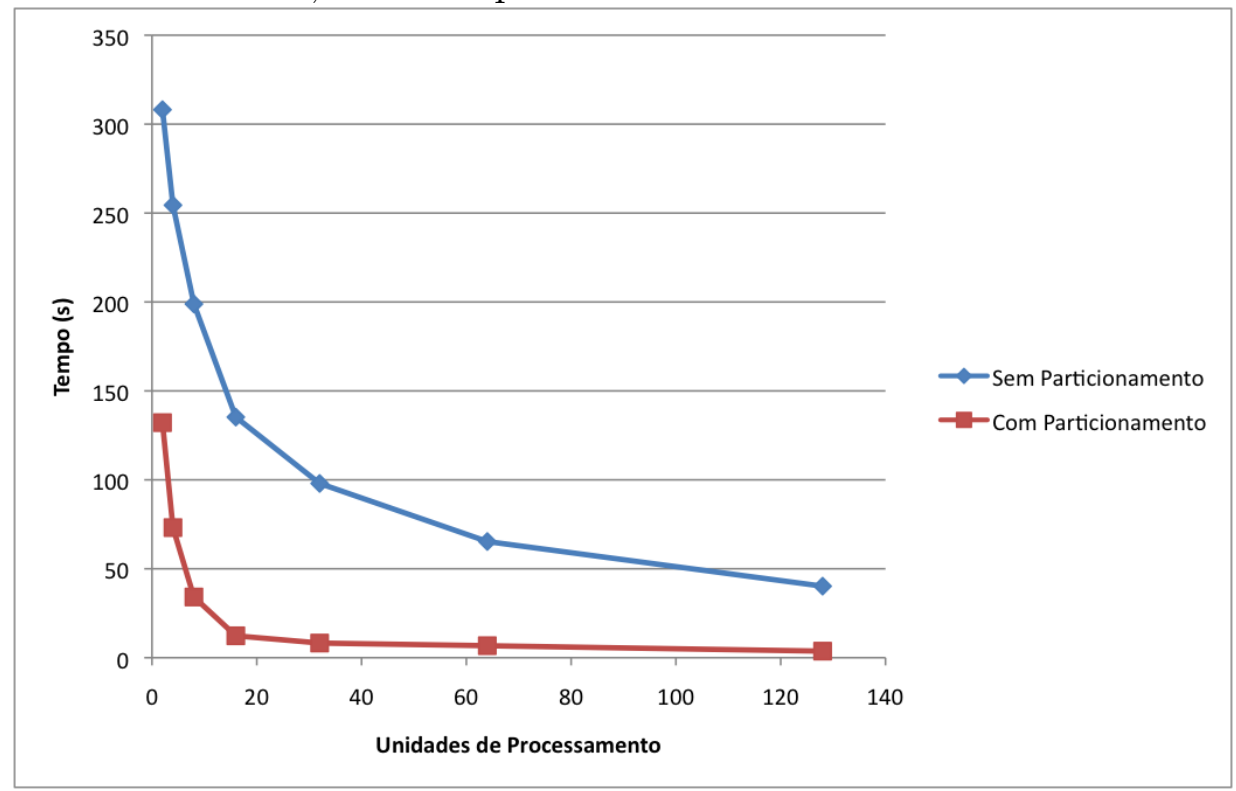

houve redução global do tempo de execução. Analisando-se todas as execuções, a redução global média foi da ordem de $65 \%$ do tempo de processamento, o que mostra uma boa melhora no desempenho. É importante ressaltar que, com a execução, na última fase, da heurística de Simulated Annealing paralela, o aumento do tempo comumente proporcionado por esta heurística é minimizado. Isso é válido pois, apesar de ser uma heurística computacionalmente custosa, os efeitos positivos que ela provoca na qualidade final dos alinhamento são vantajosos.

De modo a verificar a escalabilidade da estratégia implementada na primeira fase do algoritmo, o terceiro teste foi realizado com um conjunto de 3000 sequências de nucleotídeos, com cada sequência contendo 2000 pares de base (comprimento). Como pode ser observado no gráfico da figura 24, com o aumento do número de sequências e, também, do seu comprimento, a diferença entre os tempos obtidos pela abordagem particionada e pela abordagem não particionada aumenta significativamente. Com uma análise mais precisa, verifica-se que houve uma redução média do tempo de processamento da ordem de $83 \%$. A partir deste caso de teste, mostra-se inviável o cálculo do ganho de desempenho, pois a execução com apenas um processo assume proporções de tempo impraticáveis, devido 
Figura 23: Execução de todas as fases da ferramenta de alinhamento, com conjunto de 400 sequências de nucleotídeos, com 500 pares de bases cada.

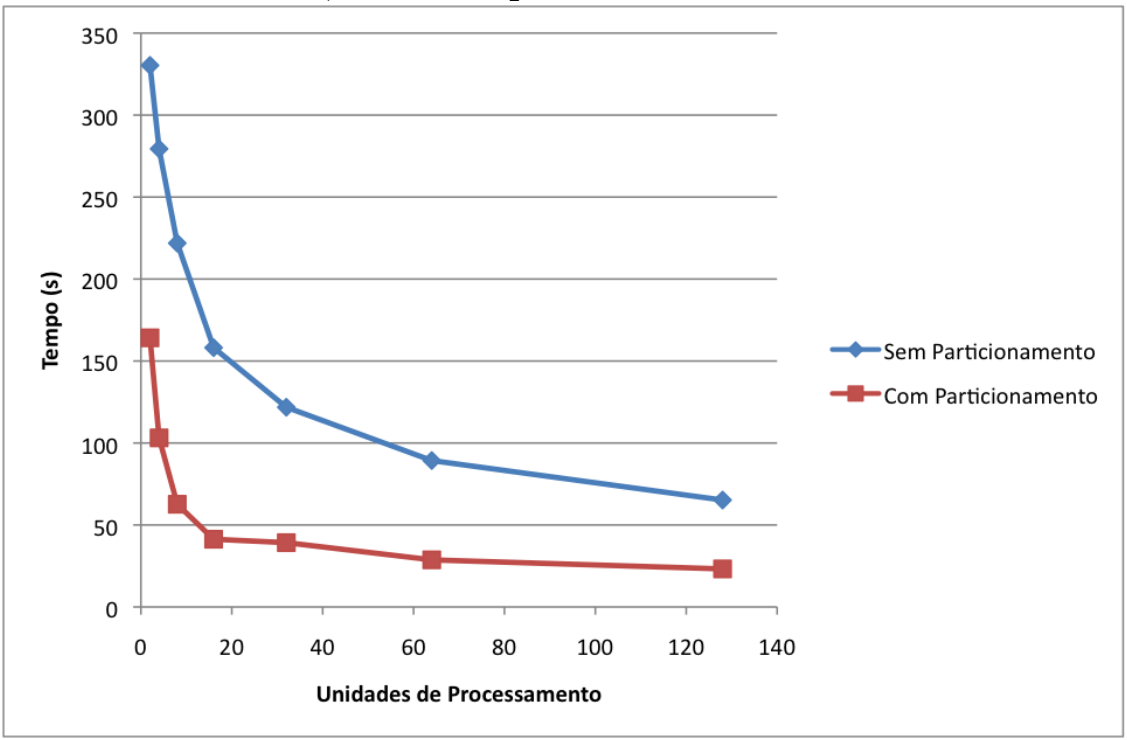

à classe NP da abordagem. Calculou-se o desvio padrão máximo do tempo de execução, que foi da ordem de 11,23.

Figura 24: Execução da construção da matriz de pontuação, com um conjunto de 3000 sequências de nucleotídeos, com 2000 pares de bases cada.

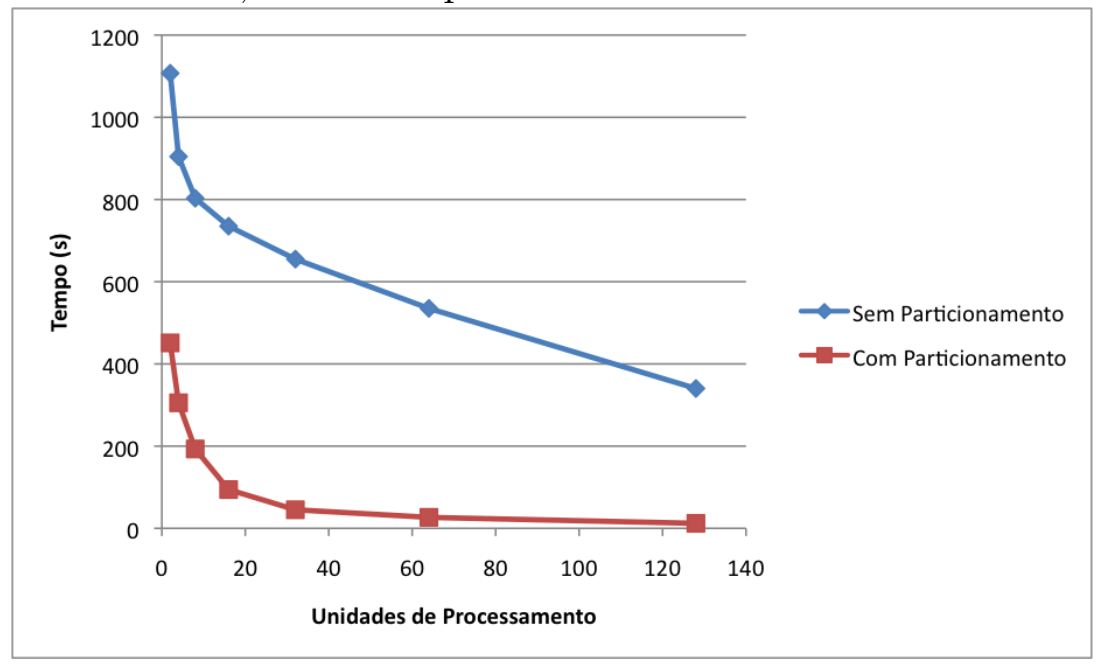

Para o mesmo terceiro teste anteriormente disposto, ao se executar a ferramenta por completo, obteve-se uma redução global média da ordem de $74 \%$. Isto mostra, conforme pode ser observado no gráfico da figura 25 , que a ferramenta se comporta adequadamente e com bons resultados, à medida que o tamanho do caso de teste aumenta. 
Figura 25: Execução de todas as fases da ferramenta de alinhamento, com conjunto de 3000 sequências de nucleotídeos, com 2000 pares de bases cada.

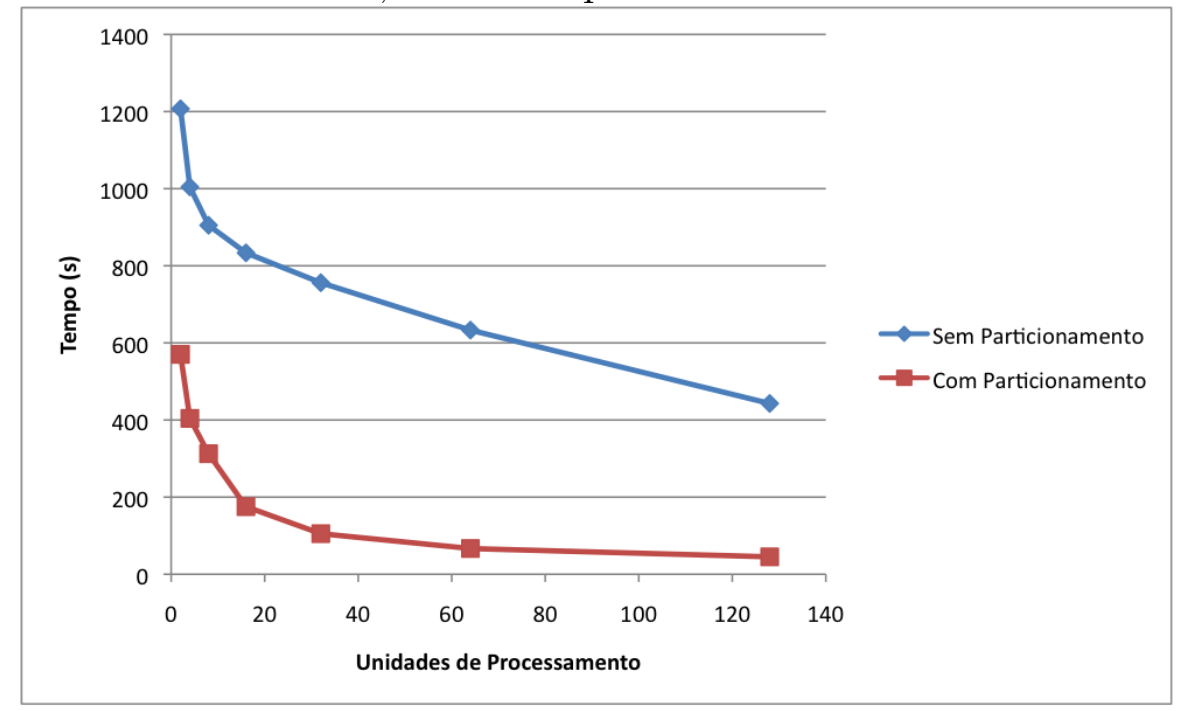

O próximo caso de teste utiliza-se de 6000 sequências de nucleotídeos, cada uma contendo 10000 pares de bases (comprimento). Neste quarto caso de teste, dobrou-se o número de sequências e quintuplicou-se o comprimento dessas sequências, em relação ao terceiro caso de teste. O resultado obtido, com a execução da primeira fase das ferramentas, pode ser conferido no gráfico da figura 26. Verifica-se que houve uma redução do tempo médio de processamento dessa fase, da abordagem com parcionamento, em relação à abordagem sem particionamento, de ordem de $80 \%$. Com isso, mantém-se a tendência de redução próxima às encontradas anteriormente. Calculou-se o desvio padrão máximo do tempo de execução, que foi da ordem de 46,14.

Com a mesma ótica dos testes anteriormente apresentados, executou-se a ferramenta por completo, com a obtenção de uma redução global média de $75 \%$. Isto pode ser verificado no gráfico apresentado na figura 27. Da mesma forma, mantém uma taxa de redução na mesma tendência das anteriores.

Um quinto e último teste foi conduzido, agora com um conjunto de 4000 sequências de nucleotídeos, com sequências de 300 a 6000 pares de bases (comprimento). Com este teste, verificou-se o comportamento da ferramenta também para tamanhos de sequências variados. No gráfico da figura 28 são apresentadas as curvas comparativas entre a abor- 
Figura 26: Execução da construção da matriz de pontuação, com um conjunto de 6000 sequências de nucleotídeos, com 10000 pares de bases cada.

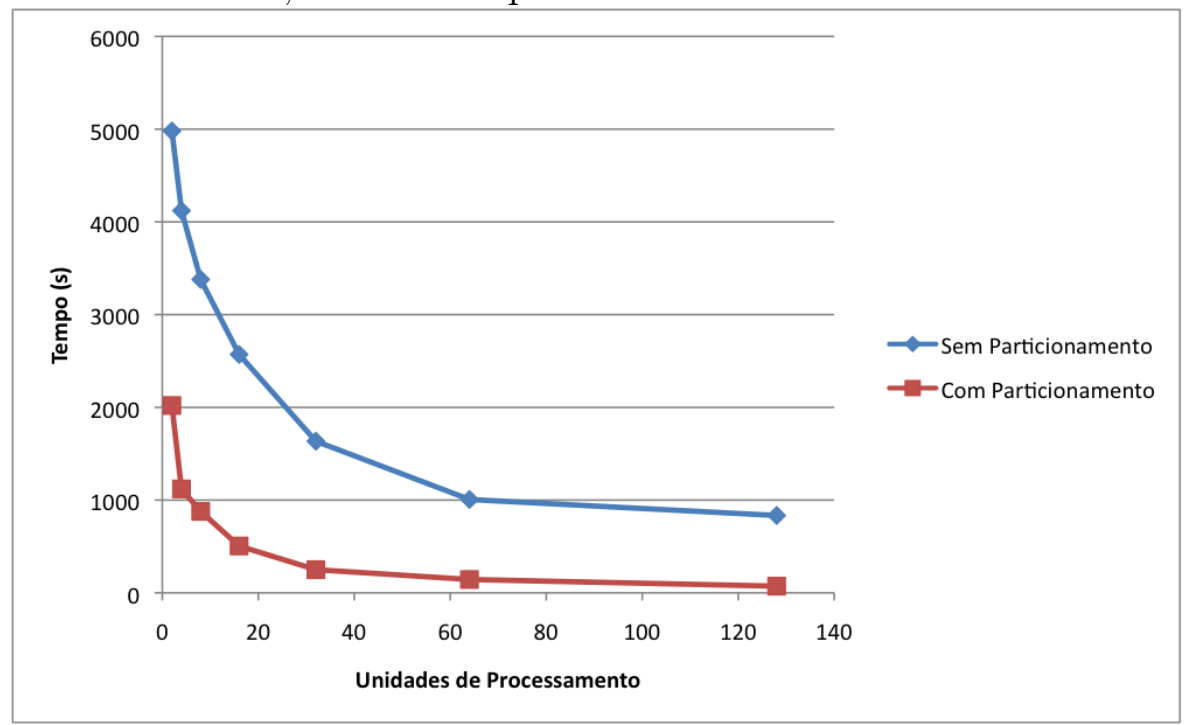

Figura 27: Execução de todas as fases da ferramenta de alinhamento, com conjunto de 6000 sequências de nucleotídeos, com 10000 pares de bases cada.

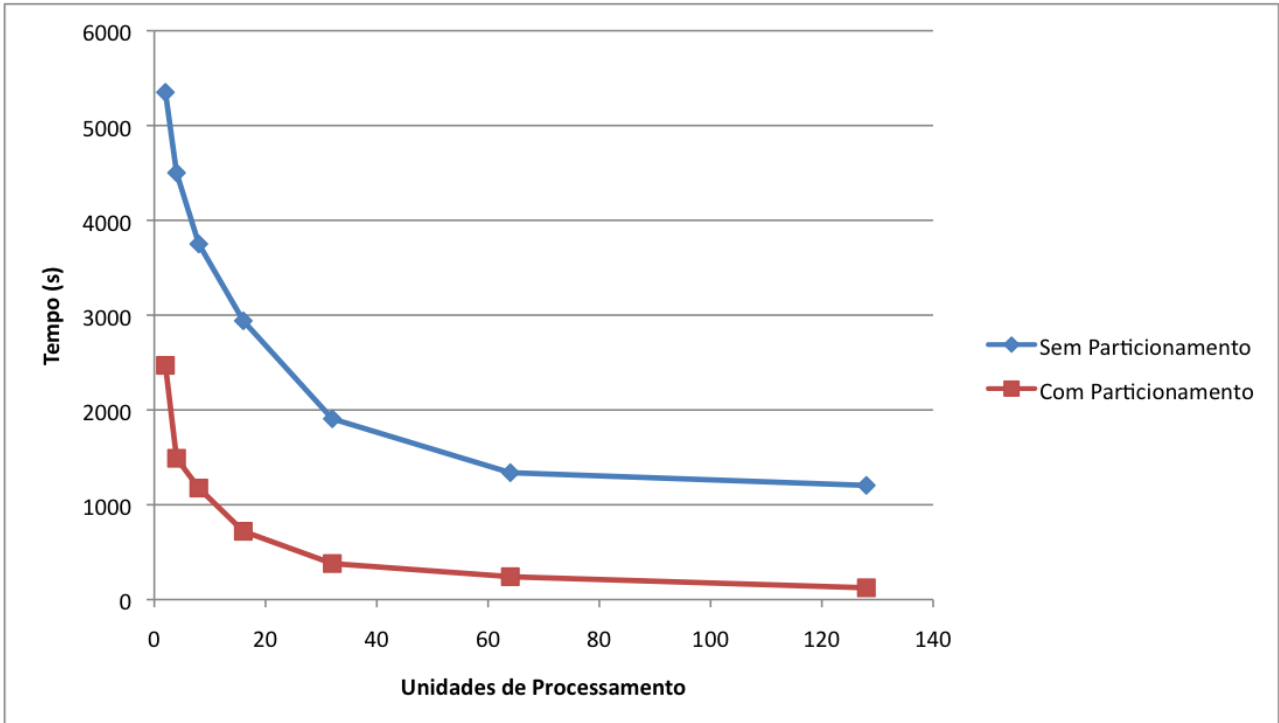


dagem particionada e a não particionada. Em uma análise mais criteriosa, verifica-se que mesmo com a utilização de estratégias híbridas, há uma redução média do tempo de processamento da primeira fase, na ferramenta com particionamento, da ordem de $45 \%$. Verifica-se uma porcentagem de redução um pouco inferior aos testes anteriores, pois para tratar sequências de tamanhos não equivalentes, aplica-se uma estratégia sem particionamento, tornando-se menos eficiente. Calculou-se o desvio padrão máximo do tempo de execução, que foi da ordem de 21,52.

Figura 28: Execução da construção da matriz de pontuação, com um conjunto de 4000 sequências de nucleotídeos, com sequências de 300 a 6000 pares de base.

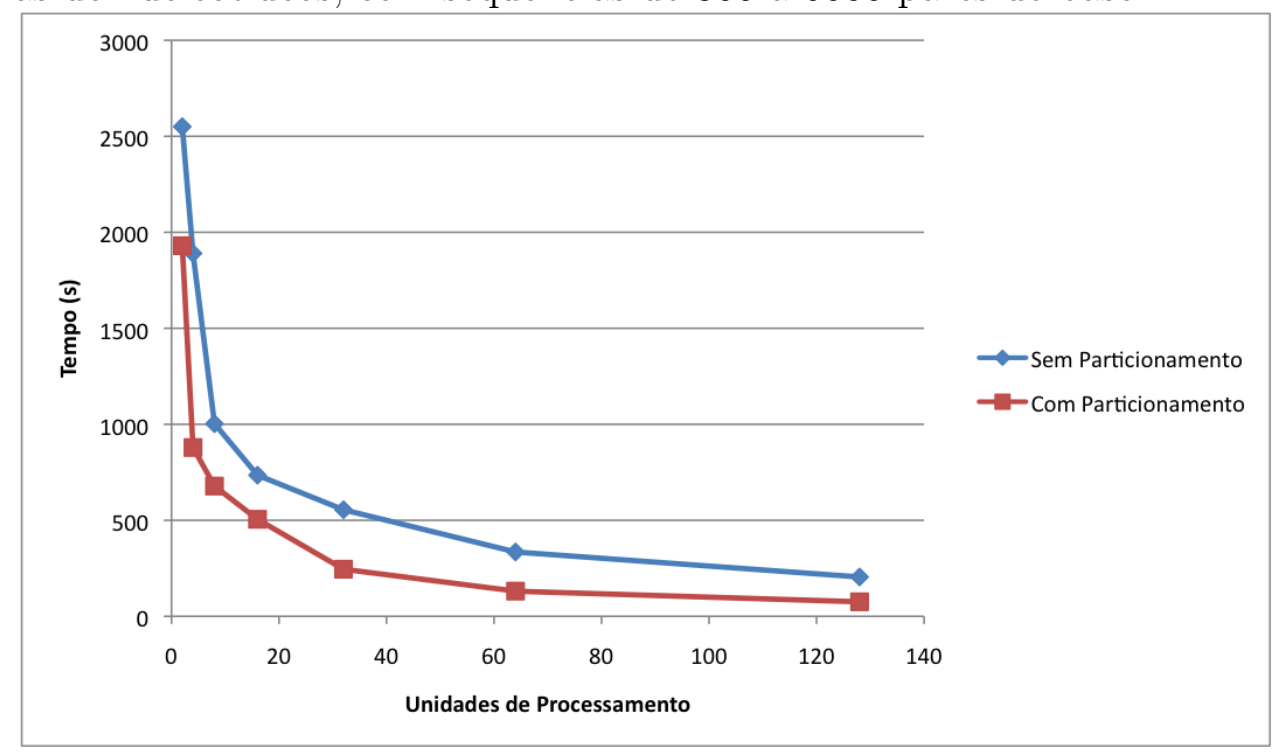

Finalmente, executou-se a ferramenta por completo, com a obtenção de uma redução global média de 40\%. Isto pode ser verificado no gráfico apresentado na figura 29. Da mesma forma, mantém-se uma taxa de redução na mesma tendência das anteriores.

\subsubsection{Construção da árvore filogenética}

No que tange a construção da árvore filogenética, é importante realizar um comentário com relação ao tempo de execução que foi otimizado, ao se utilizar a abordagem de Colônias de Formigas (ACO), no lugar da tradicional Neighbor-Joining (NJ). Pelo gráfico apresentado na figura 30, percebe-se que, quando o número de sequências é ampliado, a ascensão da curva da abordagem utilizando Colônias de Formigas é mais suave, sem 
Figura 29: Execução de todas as fases da ferramenta de alinhamento, com conjunto de 4000 sequências de nucleotídeos, com sequências de 300 a 6000 pares de base.

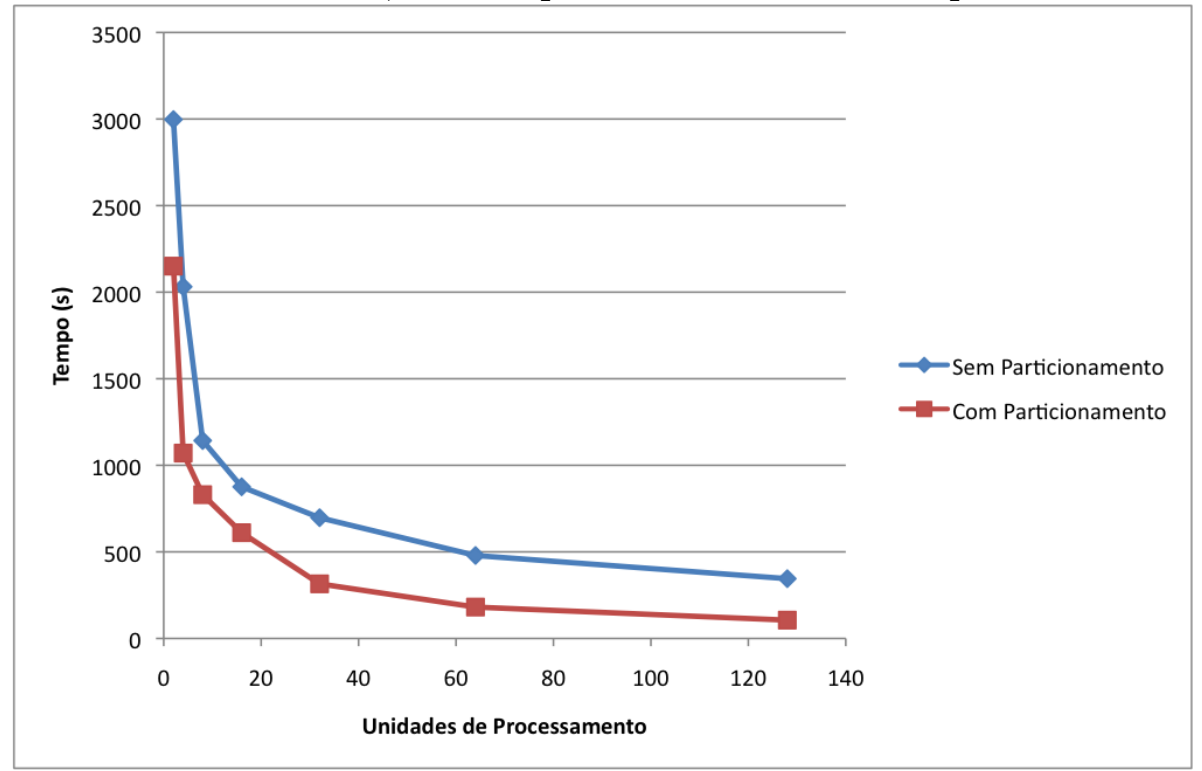

grandes oscilações, em relação à curva da abordagem com Neighbor-Joining. Além disso, os tempos apresentados pela abordagem com Colônias de Formigas são, na média, 25\% mais rápidos em relação ao Neighbor-Joining.

\subsubsection{Alinhamento múltiplo}

Do ponto de vista do alinhamento múltiplo, a utilização da heurística de Simulated Annealing, apesar de ser uma estratégia de computação massiva, oferece bons ganhos de qualidade. Quando paralelizada, o grau de comprometimento desta heurística, no tempo total, é reduzido. Para efeitos de análise, no gráfico da figura 31, destaca-se o ganho de desempenho obtido com a paralelização da heurística. Para esta análise, tomou-se as execuções para 400, 3000 e 6000 sequências apresentadas anteriormente. Neste gráfico apresentado na figura 31, percebe-se que, inicialmente, a heurística de Simulated Annealing (SAP) é mais lenta que a estratégia de Alinhamento Múltiplo Sequencial (AMS). No entanto, com o aumento da quantidade de unidade de processamento, ocorre uma redução gradual do tempo da SAP e manutenção do tempo da AMS, visto que é sequencial. 
Figura 30: Construção da Árvore Guia - Colônias de Formigas (ACO) x Neigbohr Joining (NJ).

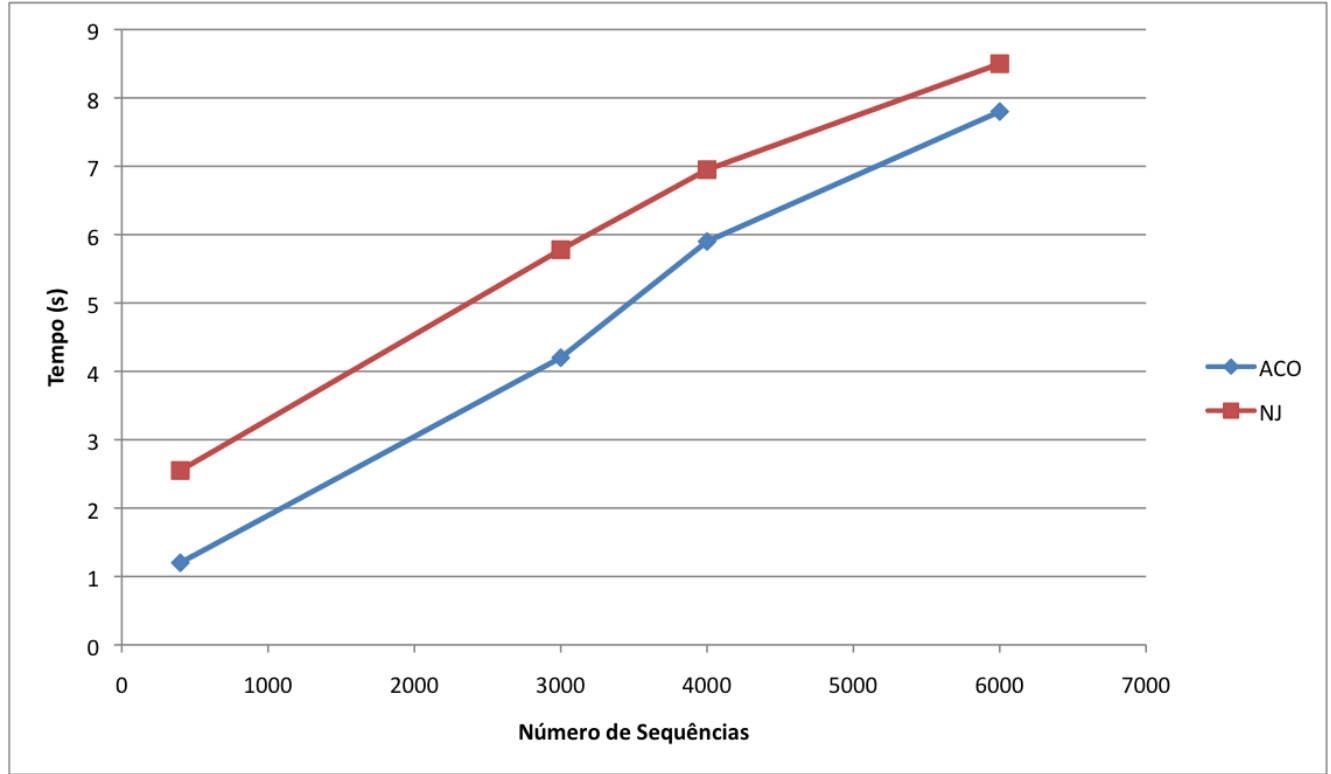

Figura 31: Fase de Alinhamento Múltiplo - Simulated Annealing Paralelo (SAP) x Alinhamento Múltiplo Sequencial (AMS).

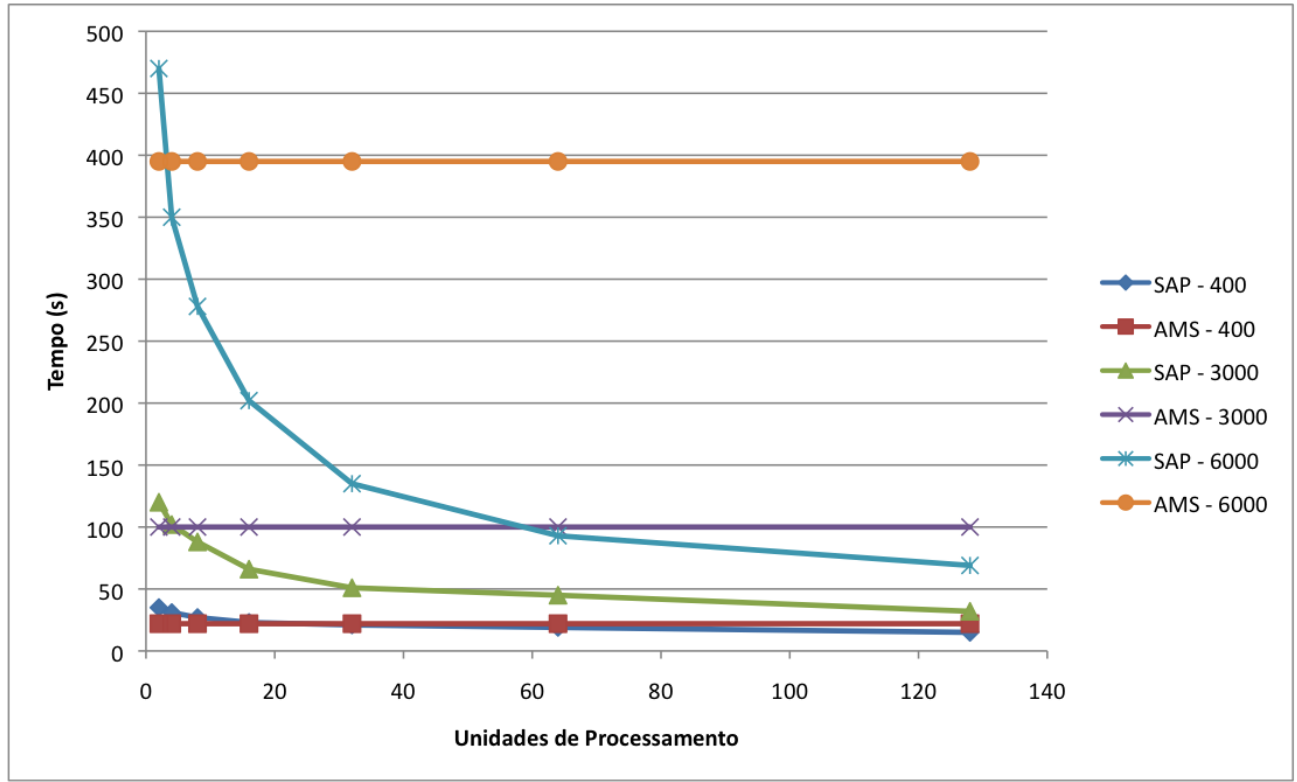




\subsection{Testes de qualidade}

Verificar o desempenho das novas estratégias desenvolvidas é um fator muito relevante. No entanto, em Bioinformática, além de se ter um bom desempenho em termos de tempo de execução, é importante que os resultados finais produzidos também sejam de qualidade, com boa significância biológica. Dessa forma, alguns testes foram realizados para mostrar os resultados finais, do ponto de vista de qualidade.

A escolha das sequências de aminoácidos para serem analisadas obedeceu um caráter aleatório e foi realizada no site BaliBase [Thompson et al. 2005] ${ }^{11}$. O BaliBase trata-se de um banco de dados de proteínas alinhadas, em que cada alinhamento dos conjuntos de sequências de aminoácidos é feito manualmente, através do estudo estrutural da proteína. Isso garante que os alinhamentos do BaliBase sejam 100\% confiáveis.

Vale notar que nestes testes de qualidade houve a execução da ferramenta por completo, ou seja, a fase do cálculo da matriz de distâncias, a construção da árvore guia baseada em Colônia de Formigas e o refinamento na fase final, utilizando-se Simulated Annealing. Com isso, produziu-se resultados mais relevantes, em termos biológicos, na comparação com outras abordagens, conforme é demonstrado na sequência.

Um primeiro teste de qualidade foi realizado sobre os resultados produzidos na máquina sequencial. Este primeiro teste é importante para ressaltar que a ferramenta produz bons resultados, em diferentes casos de teste, tanto em ambientes de pequeno porte, como em ambientes de grande porte.

Para comparação, criou-se a tabela 2, na qual são apresentados resultados de qualidade de alinhamentos produzidos na ferramenta otimizada, proposta no presente trabalho, confrontados com resultados de programas de alinhamentos múltiplos bastante conhecidos, qualificados e consagrados, como: o ClustalO ${ }^{12}$ [Sievers e Higgins 2014] e o Dialign [Morgenstern et al. 1998], ambos com suas abordagens puramente progressivas, o Saga

\footnotetext{
${ }^{11} \mathrm{http}: / /$ www.lbgi.fr/balibase/

${ }^{12}$ http://www.ebi.ac.uk/Tools/msa/clustalo/
} 
[Notredame e Higgins 1996], com sua abordagem baseada em algoritmos genéticos e o MAFFT [Katoh e Standley 2013], com uma abordagem baseada na transformada rápida de Fourier (FFT).

É importante salientar que o conjunto de genes selecionados para compor a tabela 2 é utilizado para todas as análises com conjuntos de sequências de tamanhos diferentes, de modo a manter a uniformidade para estes casos de teste. Os tamanhos das sequências que compõem esse conjunto variam de 50 à 330 aminoácidos. Mostra-se relevante informar que a coluna Genes reflete a nomenclatura do gene e a coluna Num. Seq. o número de sequências. A ferramenta proposta foi executada com 10 processos e as demais ferramentas no computador pessoal.

Tabela 2: Tabela comparativa com resultados de alguns programas de alinhamento múltiplo em relação à execução da ferramenta proposta em ambiente sequencial.

\begin{tabular}{ccccccc}
\hline Genes & Num. Seq. & Proposta & ClustalO & Dialign & Saga & MAFFT \\
\hline 1ad3_ref1 & 4 & 0,901 & 0,997 & 1,000 & 0,874 & 0,890 \\
1cpt_ref1 & 9 & 0,865 & 0,241 & 0,000 & 0,527 & 0,754 \\
1fmb_ref4 & 9 & 0,893 & 1,000 & 0,866 & 0,851 & 0,834 \\
1ubi_ref3 & 48 & 0,840 & 0,770 & 0,650 & 0,000 & 0,786 \\
1thm_ref5 & 49 & 0,826 & 0,643 & 0,234 & 0,634 & 0,678 \\
1idy_ref1 & 59 & 0.925 & 0.910 & 0.905 & 0.893 & 0.650 \\
1ldg_ref1 & 68 & 0.983 & 0.923 & 0.778 & 0.843 & 0.912 \\
1amk_ref2 & 72 & 0.783 & 0.801 & 0.765 & 0.645 & 0.532 \\
1krn_ref2 & 87 & 0.954 & 0.713 & 0.883 & 0.703 & 0.789 \\
\hline
\end{tabular}

Os valores mostrados na tabela 2 são resultados da análise comparativa feita com o programa bali_score ${ }^{13}$ com relação a cada um dos alinhamentos produzidos pelos programas. O bali_score é um programa criado pelos desenvolvedores do BaliBase que compara o grau de qualidade dos alinhamentos produzidos pelos programas existentes, em relação ao mesmo alinhamento feito manualmente no BaliBase. Quanto mais próximo de 100\% os valores da comparação alcançarem, mais bem qualificados serão os seus alinhamentos. Na tabela 2 são colocados os valores relativos, bastando multiplicá-los por 100 (cem) para obter os valores percentuais.

Percebe-se, na tabela 2, que na comparação dos resultados obtidos pelas diversas abor-

\footnotetext{
${ }^{13} \mathrm{http}$ // www.lbgi.fr/balibase/BalibaseDownload/
} 
dagens com a proposta otimizada, esta conseguiu uma melhora significativa na qualidade, em $87 \%$ dos casos testados. Em termos percentuais, a evolução média da qualidade dos resultados obtidos pela proposta otimizada, foi da ordem de $20 \%$. O valor máximo de qualidade dos alinhamentos obtido pela ferramenta proposta foi de 0,989 e o valor mínimo foi de 0,754 .

Um segundo teste de qualidade foi realizado sobre os resultados produzidos pela ferramenta proposta, agora executada no ambiente de grande porte do GridUnesp, visando mostrar que o ambiente de processamento não impacta na qualidade final. Manteve-se o mesmo conjunto de teste, com sequências de aminoácidos variando de 50 a 330 aminoácidos. A ferramenta proposta foi executada com 128 unidades de processamento e as demais ferramentas, em sua execução sequencial. Na tabela 3 ao se verificar os resultados obtidos, percebe-se que a qualidade, em relação ao teste realizado no computador pessoal, é mantida, com a ferramenta proposta oferecendo uma melhora em $81 \%$ dos casos testados. Em termos percentuais, a evolução média da qualidade dos resultados obtidos pela proposta otimizada, foi da ordem de $24 \%$. Com relação aos valores máximos e mínimos de qualidade dos alinhamentos, foram obtidos 0,991 e 0,779, respectivamente.

Tabela 3: Tabela comparativa com resultados de alguns programas de alinhamento múltiplo em relação à execução da ferramenta proposta em ambiente de grande porte.

\begin{tabular}{ccccccc}
\hline Genes & Num. Seq. & Proposta & ClustalO & Dialign & Saga & MAFFT \\
\hline 1ad3_ref1 & 4 & 0,912 & 0,997 & 1,000 & 0,874 & 0,890 \\
1cpt_ref1 & 9 & 0,879 & 0,241 & 0,000 & 0,527 & 0,754 \\
1fmb_ref4 & 9 & 0,898 & 1,000 & 0,866 & 0,851 & 0,834 \\
1ubi_ref3 & 48 & 0,876 & 0,770 & 0,650 & 0,000 & 0,786 \\
1thm_ref5 & 49 & 0,847 & 0,643 & 0,234 & 0,634 & 0,678 \\
1idy_ref1 & 59 & 0.905 & 0.910 & 0.905 & 0.893 & 0.650 \\
1ldg_ref1 & 68 & 0.988 & 0.923 & 0.778 & 0.843 & 0.912 \\
1amk_ref2 & 72 & 0.791 & 0.801 & 0.765 & 0.645 & 0.532 \\
1krn_ref2 & 87 & 0.963 & 0.713 & 0.883 & 0.703 & 0.789 \\
\hline
\end{tabular}

Um terceiro teste de qualidade foi realizado sobre os resultados produzidos pela ferramenta proposta, porém com um conjunto de teste com sequências de aminoácidos de tamanhos equivalentes, contendo 420 aminoácidos cada. Este conjunto é utilizado em todos os casos de teste para sequências de tamanho equivalente, de modo a manter a 
uniformidade nas análises. Novamente, a ferramenta foi executada no ambiente de grande porte do GridUnesp, com 128 unidades de processamento e as demais ferramentas, em sua execução sequencial. Na tabela 4, ao se verificar os resultados obtidos, percebe-se que a ferramenta proposta é melhor em $75 \%$ dos casos testados. Em termos percentuais, a evolução média da qualidade dos resultados obtidos pela proposta otimizada, foi da ordem de $21 \%$. O valor máximo de qualidade dos alinhamentos obtido pela ferramenta proposta foi de 0,998 e o valor mínimo foi de 0,770 .

Tabela 4: Tabela comparativa com resultados de alguns programas de alinhamento múltiplo em relação à execução da ferramenta proposta em ambiente de grande porte, com sequências de tamanhos equivalentes.

\begin{tabular}{ccccccc}
\hline Genes & Num. Seq. & Proposta & ClustalO & Dialign & Saga & MAFFT \\
\hline 1ad2_ref1 & 3 & 0,934 & 0,902 & 0,764 & 0,821 & 0,790 \\
1ar5A_ref1 & 4 & 0,863 & 0,911 & 0,631 & 0,640 & 0,723 \\
1ad4_ref1 & 8 & 0,998 & 0,890 & 0,879 & 0,882 & 0,932 \\
1aho_ref1 & 9 & 0,773 & 0,732 & 0,703 & 0,000 & 0,689 \\
\hline
\end{tabular}

Uma informação importante a ser ressaltada é que cada um dos programas utilizados para comparação objetiva a pontuação máxima do alinhamento entre as biossequências. No entanto, verifica-se uma diferença entre a abordagem prosposta e os demais programas nas tabelas anteriores, pois a abordagem proposta sofre menos variações na pontuação final encontrada, do que a análise feita pelos demais programas. Isso não significa que os outros programas são ruins ou inconstantes e isso pode ser explicado considerando que a abordagem proposta objetiva analisar de forma mais global as biossequências, através de uma heurística mais generalizada, não buscando por uma determinada característica. Os demais programas apresentados, em geral, podem se comportar muito bem para determinados casos, não mantendo uma uniformidade nos valores, pois prezam por procurar algumas características específicas em suas análises.

O quarto teste de qualidade realizado sobre os resultados produzidos pela ferramenta proposta mantém a sua execução no ambiente de grande porte do GridUnesp. Porém, retorna-se ao conjunto de sequências de aminoácidos variando de 50 a 330 aminoácidos. Estes resultados, agora são confrontados com os resultados obtidos com a execução no 
ClustalW-MPI. Tanto a ferramenta proposta, quanto o ClustalW-MPI, foram executadas com 128 unidades de processamento. Na tabela 5, percebe-se que a ferramenta proposta produz resultados com maior qualidade em $79 \%$ dos casos testados. Em termos percentuais, o aumento médio da qualidade dos resultados obtidos pela proposta otimizada, foi da ordem de 22,5\%. O valor máximo de qualidade dos alinhamentos obtido pela ferramenta proposta foi de 0,982 e o valor mínimo foi de 0,868 .

Tabela 5: Tabela comparativa com resultados da execução da ferramenta proposta e do ClustalW-MPI, em ambiente de grande porte.

\begin{tabular}{cccc}
\hline Genes & Num. Seq. & Proposta & ClustalW-MPI \\
\hline 1ad3_ref1 & 4 & 0,926 & 0,904 \\
1cpt_ref1 & 9 & 0,894 & 0,625 \\
1fmb_ref4 & 9 & 0,898 & 0,991 \\
1ubi_ref3 & 48 & 0,902 & 0,879 \\
1thm_ref5 & 49 & 0,931 & 0,901 \\
1idy_ref1 & 59 & 0.875 & 0.910 \\
1ldg_ref1 & 68 & 0.896 & 0.722 \\
1amk_ref2 & 72 & 0.891 & 0.893 \\
1krn_ref2 & 87 & 0.967 & 0.741 \\
\hline
\end{tabular}

Realizou-se o quinto e último teste de qualidade sobre os resultados produzidos pela ferramenta proposta e pelo ClustalW-MPI, porém com sequências de aminoácidos de tamanhos equivalentes, contendo 420 aminoácidos cada. Manteve-se a sua execução no ambiente de grande porte do GridUnesp, com 128 unidades de processamento. Na tabela 6, percebe-se que a ferramenta proposta produz melhores resultados em $75 \%$ dos casos testados. Em termos percentuais, o aumento médio da qualidade dos resultados obtidos pela proposta otimizada, foi da ordem de 18,75\%. Por fim, com relação aos valores máximos e mínimos de qualidade dos alinhamentos, foram obtidos 0,996 e 0,873, respectivamente.

Tabela 6: Tabela comparativa com resultados da execução da ferramenta proposta e do ClustalW-MPI, em ambiente de grande porte, com sequências de tamanhos equivalentes.

\begin{tabular}{cccc}
\hline Genes & Num. Seq. & Proposta & ClustalW-MPI \\
\hline 1ad2_ref1 & 3 & 0,926 & 0,899 \\
1ar5A_ref1 & 4 & 0,876 & 0,918 \\
1ad4_ref1 & 8 & 0,991 & 0,957 \\
1aho_ref1 & 9 & 0,883 & 0,871 \\
\hline
\end{tabular}

Os testes de qualidade realizados compararam os resultados da ferramenta proposta 
com os resultados de algumas das ferramentas de alinhamento múltiplo de sequências conhecidas e utilizadas pela comunidade científica em geral. Todavia, isso não significa que não existam outras ferramentas de alinhamento múltiplo e que os resultados da ferramenta proposta porventura possam ser comparados com elas. 


\section{Conclusões}

Apresentou-se, no presente trabalho, uma visão de como se encontra o estado da arte em Bioinformática, mais especificadamente com relação às técnicas para alinhamentos múltiplos de sequências e otimizações, agregadas às técnicas de computação de alto desempenho.

No presente trabalho, utilizou-se um algoritmo de alinhamento múltiplo progressivo, o qual foi otimizado em suas três fases: na fase da construção da matriz de pontuação, com uma estratégia com paralelismo entre as múltiplas sequências e o particionamento das sequências que compõem um par, na fase de construção da árvore guia, com o uso de Colônias de Formigas e, por fim, na fase de alinhamento múltiplo, utilizando a heurística de Simulated Annealing. Todas essas otimizações podem ser aplicadas em diversas outras estratégias de alinhamento múltiplo de sequência, não apenas na progressiva.

Com os testes de desempenho apresentados, verificou-se que a ferramenta proposta se comporta muito bem quando o número de processadores é aumentado, proporcionando uma redução significativa no tempo de processamento do alinhamento. Os gráficos apresentados na seção de resultados reforçam essa característica. A otimização na primeira fase da ferramenta foi fundamental para a evolução do desempenho global. No entanto, as demais fases, também otimizadas, ofereceram a sua parcela de contribuição, não apenas em relação ao tempo de processamento, mas também em relação à qualidade final do alinhamentos.

Do ponto de vista da qualidade dos alinhamentos, a ferramenta proposta destacou-se em relação a outras ferramentas de alinhamento, quando comparadas através do bali_score. 
Concluiu-se que a ferramenta proposta, através de suas heurísticas mais generalizadas, obtém soluções também mais generalizadas. Não há um direcionamento apenas para análises bem particulares, como uma boa parte das ferramentas de alinhamento múltiplo procede. Isto é muito desejável e enquadra-se bem com os propósitos dos alinhamentos de biossequências.

Finalmente, conclui-se que a estratégia otimizada da ferramenta proposta de alinhamento múltiplo promoveu ganhos de desempenho e proporcionou um aumento na qualidade dos resultados obtidos, em uma porcentagem significativa dos casos, quando comparada com as demais ferramentas utilizadas nos testes.

\subsection{Trabalhos Futuros}

O acoplamento de uma interface gráfica à ferramenta desenvolvida destaca-se como uma ideia interessante a ser avaliada como trabalho futuro. Esta necessidade deve receber uma atenção especial, pois os principais usuários deste tipo de ferramenta não são da área de computação e, portanto, utilizar uma ferramenta em modo texto, pode se tornar uma tarefa árdua. Como um outro item relevante, ainda na análise sobre a criação de uma interface gráfica, é a possibilidade de oferecer outras formas de visualização dos resultados, não apenas através de arquivos em texto plano, facilitando a realização de possíveis inferências sobre os alinhamentos.

Um trabalho que pode ser desenvolvido é a implementação das estratégias, tanto de particionamento das sequências, quanto de Simulated Annealing, no paradigma de GPGPU. Com isso, talvez seja possível reduzir ainda mais o tempo de processamento das sequências.

Sob a ótica das otimizações, a substituição das heurísticas implementadas por outras, como Algoritmos Genéticos, Swarm Particle, entre outras heurísticas evolutivas e bioinspiradas, pode promover diferentes mecanismos de otimização. 
Finalmente, é interessante acrescentar à ferramenta proposta um mecanismo de reconhecimento de padrões. Esse mecanismo funcionará sobre o alinhamento produzido e poderá facilitar a identificação de regiões importantes em um determinado conjunto de sequências. Com isso, oferece-se mais um recurso aos usuários, especificamente os da área experimental, para que possam realizar inferências, sobre determinadas regiões, sempre que possível. 


\section{Referências}

[Adams, Knowler e Leader 1992]ADAMS, R. L. P.; KNOWLER, J.; LEADER, D. P. The biochemistry of the nucleic acids. [S.l.]: Chapman and Hall, 1992.

[Altschul et al. 1990]ALTSCHUL, S. F. et al. A basic local alignment search tool. Journal of Molecular Biology, 1990.

[Andrade et al. 2006]ANDRADE, J. et al. Using grid technology for computationally intensive applied bioinformatics analyses. In Silico Biology, v. 6, n. 6, p. 495-504, 2006.

[Angiuoli e Salzberg 1994]ANGIUOLI, S. V.; SALZBERG, S. L. Mugsy: fast multiple alignment of closely related whole genomes. Nucleic Acids Research, v. 27, n. 3, p. 334342, 1994.

[Bader. et al. 2005]BADER., D. A. et al. Bioperf: a benchmark suite to evaluate highperformance computer architecture on bioinformatics applications. In: Proceedings of the IEEE International Workload Characterization Symposium. [S.l.: s.n.], 2005. p. 163-173.

[Bajorath, Stenkamp e Aruffo 1993]BAJORATH, J.; STENKAMP, R.; ARUFFO, A. Knowledge-based model building of proteins: concepts and examples. Protein Science, v. 2 , n. 11, p. 1798-1810, 1993.

[Baker, Buyya e Laforenza 2002]BAKER, M.; BUYYA, R.; LAFORENZA, D. Grids and grid technologies for wide-area distributed computing. Software: Practice and Experience, v. 32, n. 15, p. 1437-1466, 2002.

[Blum e Roli 2003]BLUM, C.; ROLI, A. Metaheuristics in combinatorial optimization: Overview and conceptual comparison. ACM Computing Surveys, v. 35, n. 3, p. 268-308, 2003.

[Borovska, Gancheva e Ko 2013]BOROVSKA, P.; GANCHEVA, V.; KO, S.-H. Scaling of parallel multiple sequence alignment on the supercomputer juqueen. In: Proceedings of the IEEE 7th International Conference on Intelligent Data Acquisition and Advanced Computing Systems (IDAACS). [S.1.: s.n.], 2013. p. 687-691.

[Brazma et al. 1998]BRAZMA, A. et al. Approaches to the automatic discovery of patterns in biosequences. Journal of Computational Biology, p. 2740-2746, 1998.

[Buyya 1999]BUYYA, R. High Performance Cluster Computing: Architectures and Systems, Volume 1. [S.l.]: Prentice Hall, 1999.

[Caminero, Carrión e Caminero 2006]CAMINERO, A.; CARRIóN, C.; CAMINERO, B. On the improvement of the network qos in a grid environment. In: Proceedings of the 4th International Workshop on Middleware for Grid Computing. [S.l.: s.n.], 2006. p. 1-2. 
[Carvalho et al. 2005]CARVALHO, P. C. et al. Squid: a simple bioinformatics grid. $B M C$ Bioinformatics, v. 6, n. 197, p. 1-4, 2005.

[Celis et al. 2000]CELIS, J. E. et al. Gene expression profiling: monitoring transcription and translation products using dna microarrays and proteomics. FEBS Letters, v. 480, n. 1, p. 2-16, 2000.

[Chai, Gao e Panda 2007]CHAI, L.; GAO, Q.; PANDA, D. K. Understanding the impact of multi-core architecture in cluster computing: A case study with intel dual-core system. In: Proceedings of the 7th IEEE International Symposium on Cluster Computing and the Grid (CCGRID 2007). [S.1.: s.n.], 2007. p. 471-478.

[Chen et al. 2012]CHEN, L. et al. An ant colony optimisation algorithm for constructing phylogenetic tree. International Journal of Computer Applications in Technology, v. 44, n. 2, p. 130-136, 2012.

[Chen e Montgomery 2011]CHEN, S.; MONTGOMERY, J. A simple strategy to maintain diversity and reduce crowding in particle swarm optimization. Advances in Artificial Intelligence - LNCS, v. 7106/2011, p. 281-290, 2011.

[Chen et al. 2006]CHEN, Y. et al. Partitioned optimization algorithms for multiple sequence alignment. In: Proceedings of the 20th International Conference on Advanced Information Networking and Applications (AINA '06). [S.l.: s.n.], 2006.

[Church et al. 2011]CHURCH, P. C. et al. Design of multiple sequence alignment algorithms on parallel, distributed memory supercomputers. In: Proceedings of the 33rd Annual International Conference of the IEEE Engineering in Medicine and Biology Society, $E M B C$. [S.l.: s.n.], 2011. p. 924-927.

[Cirne e Santos-Neto 2005]CIRNE, W.; SANTOS-NETO, E. Grids computacionais: da computação de alto desempenho a serviços sob demanda. In: Anais do Simpósio Brasileiro de Redes de Computadores - SBRC 2005. [S.1.: s.n.], 2005. p. 1-51.

[Coello 1999]COELLO, C. A. C. A comprehensive survey of evolutionary-based multiobjective optimization techniques. Knowledge and Information Systems, v. 1, n. 3, p. 269-308, 1999.

[Correa et al. 2012]CORREA, J. M. et al. Parallel simulated annealing for fragment based sequence alignment. In: Proceedings of the 26th International Parallel and Distributed Processing Symposium Workshops \& PhD Forum. [S.l.: s.n.], 2012. p. 641-648.

[Cristino]CRISTINO, A. dos S. Principais algoritmos de alinhamento de sequências genéticas. http://www.ime.usp.br/ ${ }^{2}$ alexsc - acessado em 20/01/2012.

[Czajkowski, Foster e Kesselman 1999]CZAJKOWSKI, K.; FOSTER, I.; KESSELMAN, C. Resource co-allocation in computational gris. In: Proceedings of the 8th International Symposium on High Performance Distributed Computing. [S.l.: s.n.], 1999. p. 219-228.

[DiMaio et al. 2011]DIMAIO, F. et al. Improved molecular replacement by density- and energy-guided protein structure optimization. Nature, v. 473, n. 7348, p. 540-543, 2011. 
[Dinh et al. 2010]DINH, H. Q. et al. Acophy: A simple and general ant colony optimization approach for phylogenetic tree reconstruction. Swarm Intelligence - Lecture Notes in Computer Science, v. 6234, n. 2010, p. 360-367, 2010.

[Doolittle 1990]DOOLITTLE, R. F. Molecular Evolution: Computer Analisys of Protein and Nucleic Acid Sequences. [S.l.]: Academic Press, 1990.

[Dorigo e Blum 2005]DORIGO, M.; BLUM, C. Ant colony optimization theory: A survey. Theoretical Computer Science, v. 344, p. 243-278, 2005.

[Dorigo, Caro e Gambardella 1999]DORIGO, M.; CARO, G. D.; GAMBARDELLA, L. M. Ant algorithms for discrete optmization. Artificial Life, p. 137-172, 1999.

[Dorigo e Gambardella 1997]DORIGO, M.; GAMBARDELLA, L. M. Ant colony system: A cooperative learning approach to the traveling salesman problem. IEEE Transactions on Evolutionary Computation, v. 1, n. 1, 1997.

[Díaz et al. 2014]DíAZ, D. et al. Mc64-clustalwp2: A highly-parallel hybrid strategy to align multiple sequences in many-core architectures. PLOS One, v. 9, n. 4, p. 1-12, 2014.

[Edgar e Batzoglou 2006]EDGAR, R. C.; BATZOGLOU, S. Multiple sequence alignment. Current Opinion in Structural Biology, n. 16, p. 368-373, 2006.

[Eidhammer, Jonassen e Taylor 2000]EIDHAMMER, I.; JONASSEN, I.; TAYLOR, W. R. Structure comparison and structure patterns. Journal of Computational Biology, n. 7 , p. $685-716,2000$.

[Feng e Doolittle 1987]FENG, D.-F.; DOOLITTLE, R. F. Progressive sequence alignment as a prerequisite to correct phylogenetic trees. Journal of Molecular Evolution, n. 60, p. 351-360, 1987.

[Foster e Karonis 1998]FOSTER, I.; KARONIS, N. T. A grid-enabled mpi: message passing in heterogeneous distributed computing systems. In: Proceedings of the 1998 ACM/IEEE Conference on Supercomputing. [S.l.: s.n.], 1998. p. 1-9.

[Foster e Kesselman 1997]FOSTER, I.; KESSELMAN, C. Globus: a metacomputing infrastructure toolkit. The International Journal of High Performance Computing and Applications, v. 11, n. 2, p. 115-128, 1997.

[Foster e Kesselman 1998]FOSTER, I.; KESSELMAN, C. The Grid: Blueprint for a Future Computing Infrastructure. [S.l.]: Morgan Kaufmann, 1998.

[Foster et al. 1998]FOSTER, I. et al. A security architecture for computational grids. In: Proceedings of the 5th ACM Conference on Computer and Communications Security (CCS 98). [S.l.: s.n.], 1998. p. 83-92.

[Foster, Kesselman e Tuecke 2001]FOSTER, I.; KESSELMAN, C.; TUECKE, S. The anatomy of the grid: Enabling scalable virtual organizations. The International Journal of High Performance Computing Applications, v. 15, n. 3, p. 200-222, 2001.

[Fox e Gannon 2001]FOX, G.; GANNON, D. Computational grids. Computing in Science Ef Engineering, v. 3, n. 4, p. 74-77, 2001. 
[Gallo e Pallottino 1988]GALLO, G.; PALLOTTINO, S. Shortest path algorithms. Annals of Operations Research, v. 13, n. 1, p. 1-79, 1988.

[Glover e Laguna 1997]GLOVER, F.; LAGUNA, M. Tabu Search. [S.l.]: Kluwer Academic Publishers, 1997.

[Gould 1985]GOULD, S. J. Ontogeny and Phylogeny. [S.l.]: Harvard University Press, 1985.

[Goux et al. 2001]GOUX, J.-P. et al. Master-worker: An enabling framework for applications on the computational grid. Cluster Computing, v. 4, n. 1, p. 63-70, 2001.

[Gouy, Guindon e Gascuel 2010]GOUY, M.; GUINDON, S.; GASCUEL, O. Seaview version 4: A multiplatform graphical user interface for sequence alignment and phylogenetic tree building. Molecular Biology and Evolution, v. 27, n. 2, p. 221-224, 2010.

[Gusfield 1997]GUSFIELD, D. Algorithms on Strings, Trees, and Sequences: Computer Science and Computational Biology. [S.1.]: Cambridge University Press, 1997.

[Hamada e Asai 2012]HAMADA, M.; ASAI, K. A classification of bioinformatics algorithms from the viewpoint of maximizing expected accuracy (mea). Journal of Computational Biology, v. 19, n. 5, p. 532-549, 2012.

[Hingne et al. 2003]HINGNE, V. et al. Towards a pervasive grid. In: Proceedings of the International Parallel and Distributed Processing Symposium - IPDPS'03. [S.l.: s.n.], 2003. p. $1-8$.

[Ho et al. 2005]HO, S. L. et al. An improved ant colony optimization algorithm and its application to electromagnetic devices designs. IEEE Transactions on Magnetics, v. 41, n. 5, 2005.

[Huse et al. 2007]HUSE, S. M. et al. Accuracy and quality of massively parallel dna pyrosequencing. Genome Biology, v. 8, n. R143, p. 1-9, 2007.

[Iope, Lemke e Winckler 2010]IOPE, R. L.; LEMKE, N.; WINCKLER, G. A. von. Gridunesp: a multi-campus grid infrastructure for scientific computing. In: Proceedings of the 3rd Latin American Conference on High Performance Computing. [S.l.: s.n.], 2010. p. $76-84$.

[Ishikawa et al. 1993]ISHIKAWA, M. et al. Multiple sequence alignment by parallel simulated annealing. Bioinformatics, v. 9, n. 3, p. 267-273, 1993.

[Jackson et al. 2010]JACKSON, K. R. et al. Performance analysis of high performance computing applications on the amazon web services cloud. In: Proceedings of the IEEE Second International Conference on Cloud Computing Technology and Science (CloudCom). [S.l.: s.n.], 2010. p. 159-168.

[Kalos 2007]KALOS, M. H. Monte carlo methods in th physical sciences. In: Proceedings of the 2007 Winter Simulation Conference. [S.l.: s.n.], 2007. p. 266-271.

[Karonis, Toonen e Foster 2003]KARONIS, N. T.; TOONEN, B.; FOSTER, I. Mpich-g2: A grid-enabled implementation of the message passing interface. Journal of Parallel and Distributed Computing, v. 63, n. 5, p. 551-563, 2003. 
[Katoh e Standley 2013]KATOH, K.; STANDLEY, D. M. Mafft multiple sequence alignment software version 7: Improvements in performance and usability. Molecular Biology and Evolution, v. 30, n. 4, p. 772-780, 2013.

[Katoh e Toh 2010]KATOH, K.; TOH, H. Parallelization of the mafft multiple sequence alignment program. Bioinformatics, v. 26, n. 15, p. 1899-1900, 2010.

[Keller et al. 2011]KELLER, O. et al. A novel hybrid gene prediction method employing protein multiple sequence alignments. Bioinformatics, v. 27, n. 6, p. 757-763, 2011.

[Kent 2002]KENT, W. J. Blat - the blast-like alignment tool. Genome Research, v. 12, n. 4 , p. $656-664,2002$.

[Kim, Pramanik e Chung 1994]KIM, J.; PRAMANIK, S.; CHUNG, M. J. Multiple sequence alignment using simulated annealing. Oxford Journals - Bioinformatics, v. 10, p. 419-426, 1994.

[Kirkpatrick, Gelatt e Vecchi 1983]KIRKPATRICK, S.; GELATT, C. D.; VECCHI, M. P. Optmization by simulated annealing. Science, n. 220, p. 671-680, 1983.

[Krieger e Vriend 2002]KRIEGER, E.; VRIEND, G. Models@home: distributed computing in bioinformatics using a screensaver based approach. Bioinformatics, v. 18, n. 2, p. 315-318, 2002.

[Lee e Chen 2002]LEE, Y.-M.; CHEN, C.-P. Power grid transient simulation in linear time based on transmission-line-modeling alternating-direction-implicit method. IEEE Transactions on Computer-Aided Design of Integrated Circuits and Systems, v. 21, n. 11, p. $1343-1352,2002$.

[Lemos, Aragão e Casanova 2003]LEMOS, M.; ARAGãO, M. V. S. P. de; CASANOVA, M. A. Padrões em biosseqüências. [S.1.], 2003.

[Lemos e Casanova 2000]LEMOS, M.; CASANOVA, M. A. Algoritmos para análise de seqüências. [S.l.], 2000.

[Li et al. 2010]LI, G. et al. A novel method for pairwise alignment based on an ant colony algorithm. Journal of Computational and Theoretical Nanoscience, v. 7, n. 10, p. 20132018, 2010.

[Li 2003]LI, K.-B. Clustalw-mpi: Clustalw analysis using distributed and parallel computing. Bioinformatics, v. 19, n. 12, p. 1585-1586, 2003.

[Liew, Yan e Yang 2005]LIEW, A. W.-C.; YAN, H.; YANG, M. Pattern recognition for the emerging field of bioinformatics: a review. Pattern Recogntion, Science Direct, n. 38, p. 2055-2073, 2005.

[Lipman e Pearson 1985]LIPMAN, D. J.; PEARSON, W. R. Rapid and sensitive protein similarity search. Science, n. 227, p. 1435-1441, 1985.

[Litzkow, Livny e Mutka 1998]LITZKOW, M. J.; LIVNY, M.; MUTKA, M. W. Condor - a hunter of idle workstations. In: Proceedings of the 8th International Conference on Distributed Computing System. [S.l.: s.n.], 1998. p. 104-111. 
[Liu e Schmidt 2014]LIU, Y.; SCHMIDT, B. Multiple protein sequence alignment with msaprobs. Multiple Sequence Alignment Methods - Methods in Molecular Biology, v. 1079, n. 1, p. 211-218, 2014.

[Lo 1988]LO, V. M. Heuristic algorithms for task assignment in distributed systems. IEEE Transactions on Computers, v. 37, n. 11, p. 1384-1397, 1988.

[Mareuil et al. 2011]MAREUIL, F. et al. Grid computing for improving conformational sampling in nmr structure calculation. Bioinformatics, v. 27, n. 12, p. 1713-1714, 2011.

[Mehlhorn 1984]MEHLHORN, K. Graph algorithms and NP-completeness. [S.l.]: Springer-Verlag, 1984.

[Milne et al. 2009]MILNE, I. et al. Topali v2: a rich graphical interface for evolutionary analyses of multiple alignments on hpc clusters and multi-core desktops. Bioinformatics, v. 25, n. 1, p. 126-127, 2009.

[Montañola et al. 2013]MONTAñOLA, A. et al. Performance analysis of computational approaches to solve multiple sequence alignment. The Journal of Supercomputing, v. 64, n. 1, p. $69-78,2013$.

[Morgenstern et al. 1998]MORGENSTERN, B. et al. Dialign: finding local similarities by multiple sequence alignment. Bioinformatics, v. 14, n. 3, p. 290-294, 1998.

[Moss e Johnson 2003]MOSS, J.; JOHNSON, C. G. An ant colony algorithm for multiple sequence alignment in bioinformatics. Artificial Neural Networks and Genetic Algorithms, p. 182-186, 2003.

[Murty e Kabadi 1987]MURTY, K. G.; KABADI, S. N. Some np-complete problems in quadratic and nonlinear programming. Mathematica Programming, v. 39, n. 2, p. 117129, 1987.

[Needleman e Wunsch 1970]NEEDLEMAN, S. B.; WUNSCH, C. D. A general method applicable to the search for similarities in the amino acid sequence of two proteins. Journal of Molecular Biology, n. 48, p. 443-453, 1970.

[Nei e Saito 1987]NEI, M.; SAITO, N. The neighbor-joining method: a new method for reconstructing phylogenetic trees. Molecular Biology and Evolution, n. 4, p. 406-425, 1987.

[Notredame e Higgins 1996]NOTREDAME, C.; HIGGINS, D. Saga: sequence alignment by genetic algorithm. Nucleic Acid Research, v. 24, n. 8, p. 1515-1524, 1996.

[Pacheco 1997]PACHECO, P. S. Parallel Programming with MPI. [S.l.]: Morgan Kaufmann, 1997.

[Papadimitriou e Steiglitz 1982]PAPADIMITRIOU, C.; STEIGLITZ, K. Combinatorial Optimization - Algorithms and Complexity. [S.l.]: Dover Publications Inc., 1982.

[Parke et al. 2013]PARKE, T. et al. Using hpc for teaching and learning bioinformatics software: Benefits and challenges. BMC Bioinformatics, A18, n. 14, p. 1, 2013. 
[Passino 2010]PASSINO, K. M. Bacterial foraging optimization. International Journal of Swarm Intelligence Research, v. 1, n. 1, p. 1-16, 2010.

[Passino 2012]PASSINO, K. M. Biomimicry of bacterial foraging for distributed optimization and control. IEEE Control Systems, v. 22, n. 3, p. 52-67, 2012.

[Pearson e Lipman 1988]PEARSON, W. R.; LIPMAN, D. J. Improved tools for biological sequence comparison. In: Proceedings of the National Academy of Sciences of the U.S.A. [S.l.: s.n.], 1988. p. 2444-2448.

[Perretto e Lopes 2005]PERRETTO, M.; LOPES, H. S. Reconstruction of phylogenetic trees using the ant colony optimization paradigm. Genetics and Molecular Research, v. 4, n. 3, p. 581-589, 2005.

[Pierri, Parisi e Porcelli 2010]PIERRI, C. L.; PARISI, G.; PORCELLI, V. Computational approaches for protein function prediction: A combined strategy from multiple sequence alignment to molecular docking-based virtual screening. Biochimica et Biophysica Acta (BBA) - Proteins and Proteomics, v. 1804, n. 9, p. 1695-1712, 2010.

[Plyusnin e Holm 2005]PLYUSNIN, I.; HOLM, L. Comprehensive comparison of graph based multiple protein sequence alignment strategies. BMC Bioinformatics, v. 15, n. 64, p. 1-11, 2005.

[Psomopoulos e Mitkas 2010]PSOMOPOULOS, F. E.; MITKAS, P. A. Bioinformatics algorithm development for grid environments. Journal of Systems and Software, v. 83, n. 7 , p. 1249-1257, 2010.

[Qiang et al. 2013]QIANG, L. et al. A parallel ant colonies approach to de novo predicition of protein backbone in casp8/9. Journal of Bioinformatics and Computational Biology, v. 56, n. 10, p. 1-13, 2013.

[Rani e Reddy 2012]RANI, P. R.; REDDY, P. R. K. The evaluation of soft computing techniques in bioinformatics. Computer Science Chronicle, v. 1, n. 1, p. 1-9, 2012.

[Riaz, Wang e Li 2004]RIAZ, T.; WANG, Y.; LI, K.-B. Multiple sequence alignment using tabu search. In: Proceedings of the 2nd conference on Asia-Pacific bioinformatics. [S.l.: s.n.], 2004. p. 223-232.

[Riaz, Yi e Li 2005]RIAZ, T.; YI, W.; LI, K.-B. A tabu search algorithm for postprocessing multiple sequence alignment. Journal of Bioinformatics and Computational Biology, v. 3, n. 1, p. 145-156, 2005.

[Rius et al. 2011]RIUS, J. et al. A user-friendly web portal for t-coffee on supercomputers. BMC Bioinformatics, v. 12, n. 150, p. 1-6, 2011.

[Roshan 2014]ROSHAN, U. Multiple sequence alignment using probcons and probalign. Multiple Sequence Alignment Methods - Methods in Molecular Biology, v. 1079, n. 1, p. 147-153, 2014.

[Rouchka 2006]ROUCHKA, E. C. Aligning dna sequences using dynamic programming. The ACM Student Magazine, v. 3, n. 1, 2006. 
[Rubin et al. 2000]RUBIN, G. M. et al. Comparative genomics of the eukaryotes. Science, v. 287, n. 5461, p. 2204-2215, 2000.

[Sadasivam e Baktavatchalam 2010]SADASIVAM, G. S.; BAKTAVATCHALAM, G. A novel approach to multiple sequence alignment using hadoop data grids. In: Proceedings of the 2010 Workshop on Massive Data Analytics on the Cloud. [S.1.: s.n.], 2010. p. 1-7.

[Schmidt 2011]SCHMIDT, B. Bioinformatics: High Performance Parallel Computer Architechtures. [S.l.]: CRC Press, 2011.

[Schmollinger et al. 2004]SCHMOLLINGER, M. et al. Dialign p: Fast pair-wise and multiple sequence alignment using parallel processors. BMC Bioinformatics, v. 5, n. 128, p. 1-6, 2004.

[Segal 2000]SEGAL, B. Grid computing: The european data project. In: Proceedings of the 2000 IEEE Nuclear Science Symposium and Medical Imaging Conference. [S.l.: s.n.], 2000. p. $15-20$.

[Shao e Chen 2009]SHAO, L.; CHEN, Y. Bacterial foraging optimization algorithm integrating tabu search for motif discovery. In: Proceedings of the IEEE International Conference on Bioinformatics and Biomedicine. [S.l.: s.n.], 2009. p. 415-418.

[Sievers e Higgins 2014]SIEVERS, F.; HIGGINS, D. G. Clustal omega, accurate alignment of very large numbers of sequences. Multiple Sequence Alignment Methods - Methods in Molecular Biology, v. 1079, n. 1, p. 105-116, 2014.

[Sievers et al. 2011]SIEVERS, F. et al. Fast, scalable generation of high-quality protein multiple sequence alignments using clustal omega. Molecular Systems Biology, v. 7, n. 1, p. 1-6, 2011.

[Skillicorn 2002]SKILLICORN, D. B. Motivating computational grids. In: Proceedings of the 2nd IEEE/ACM International Symposium on Cluster Computing and the Grid. [S.l.: s.n.], 2002. p. 401-415.

[Smith e Waterman 1981]SMITH, T.; WATERMAN, M. Identification of common molecular subsequences. Journal of Molecular Biology, v. 147, n. 1, p. 195-197, 1981.

[Stockinger et al. 2006]STOCKINGER, H. et al. Grid approach to embarrassingly parallel cpu-intensive bioinformatics problems. In: Proceedings of the Second IEEE International Conference on e-Science and Grid Computing. [S.l.: s.n.], 2006. p. 58-58.

[Sun et al. 2012]SUN, J. et al. Multiple sequence alignment using the hidden markov model trained by an improved quantum-behaved particle swarm optimization. Information Sciences, v. 182, n. 1, p. 93-114, 2012.

[Sun et al. 2007]SUN, Y. et al. Abcgrid: Application for bioinformatics computing grid. Bioinformatics, v. 23, n. 9, p. 1175-1177, 2007.

[Tan e Strazdins 2002]TAN, W. B.; STRAZDINS, P. The analysis and optimization of collective communications on a beowulf cluster. In: Proceedings of the 9th International Conference on Parallel and Distributed Systems (ICPADS'02). [S.l.: s.n.], 2002. p. 659666. 
[Thompson, Higgins e Gibson 1994]THOMPSON, J. D.; HIGGINS, D. G.; GIBSON, T. J. Clustal w: improving the sensitivity of progressive multiple sequence alignment through sequence weighting, position-specific gap penalties and weight matrix choice. Nucleic Acids Research, v. 22, n. 22, p. 4673-4680, 1994.

[Thompson et al. 2005]THOMPSON, J. D. et al. Balibase 3.0: Latest developments of the multiple sequence alignment benchmark. Proteins: Structure, Function, and Bioinformatics, v. 61, n. 1, p. 127-136, 2005.

[Tommaso et al. 2014]TOMMASO, P. D. et al. Sara-coffee web server, a tool for the computation of rna sequence and structure multiple alignments. Nucleic Acids Research, v. 42, n. W1, p. W356-W360, 2014.

[Torrie e Valleau 1974]TORRIE, G. M.; VALLEAU, J. P. Monte carlo free energy estimates using non-boltzmann sampling: Application to the sub-critical lennard-jones fluid. Chemical Physics Letters, v. 28, n. 4, p. 578-581, 1974.

[Vivekanandana e Ramyachitrab 2012]VIVEKANANDANA, K.; RAMYACHITRAB, D. Bacteria foraging optimization for protein sequence analysis on the grid. Future Generation Computer Systems, v. 28, n. 4, p. 647-656, 2012.

[Wallace, Blackshields e Higgins 2005]WALLACE, I. M.; BLACKSHIELDS, G.; HIGGINS, D. G. Multiple sequence alignment. Current Opinion in Structural Biology, n. 15, p. 261-266, 2005.

[Watson e Crick 1953]WATSON, J. D.; CRICK, F. H. C. The structure of dna. In: Proceedings of the 1953 Cold Spring Harbor Symposia on Quantitative Biology. [S.l.: s.n.], 1953. p. $123-131$.

[Whitman, Coleman e Wiebe 1998]WHITMAN, W. B.; COLEMAN, D. C.; WIEBE, W. J. Prokaryotes: The unseen majority. In: Proceedings of the National Academy of Sciences of the United States of America. [S.l.: s.n.], 1998. p. 6578-6583.

[Yang et al. 2011]YANG, X. liang et al. Parallelization of blast with mapreduce for long sequence alignment. In: Proceedings of the Fourth International Symposium on Parallel Architectures, Algorithms and Programming (PAAP). [S.1.: s.n.], 2011. p. 241-246.

[Zafalon 2009]ZAFALON, G. F. D. Implementação de algoritmos de alinhamento múltiplo e técnicas de otimização para esses algoritmos utilizando Ant Colony. Dissertação (Mestrado) — Universidade Estadual Paulista - Unesp, 2009.

[Zhou et al. 2007]ZHOU, D. et al. Separation of near full-length hepatitis c virus quasispecies variants from a complex population. Journal of Virological Methods, n. 141, p. 220-224, 2007.

[Zhou et al. 2010]ZHOU, X. et al. An ant colony pairwise alignment based on the simplified grid. Journal of Computational and Theoretical Nanoscience, v. 7, n. 1, p. 277-280, 2010 .

[Zhu et al. 2011]ZHU, H. et al. Paralleling genetic annealing algorithm on grid. In: Proceedings of the 14th International Conference on Intelligent Networks and Intelligent Systems (ICINIS). [S.l.: s.n.], 2011. p. 89-92. 
[Zhu et al. 2006]ZHU, J. et al. Analysis of the bioinformatics grid technique applications in china. In: Proceedings of the Sixth IEEE International Symposium on Cluster Computing and the Grid. [S.l.: s.n.], 2006. p. 44-44.

[Zomaya 2006]ZOMAYA, A. Y. Parallel Computing for Bioinformatics and Computational Biology: Models, Enabling Technologies, and Case Studies. [S.l.]: John Wiley \& Sons, 2006.

[Zomaya, Ercal e Olariu 2001]ZOMAYA, A. Y.; ERCAL, F.; OLARIU, S. Solutions to parallel and distributed computing problems - Lessons from biological sciences. [S.l.]: John Wiley \& Sons, 2001. 